\title{
A Critical Evaluation of High-Temperature Gas-Cooled Reactors Applicable to Coal Conversion
}
I. Spiewak
J. E. Jones Jr.
P. L. Rittenhouse
J. R. DiStefano
J. G. Delene 


\section{DISCLAIMER}

This report was prepared as an account of work sponsored by an agency of the United States Government. Neither the United States Government nor any agency Thereof, nor any of their employees, makes any warranty, express or implied, or assumes any legal liability or responsibility for the accuracy, completeness, or usefulness of any information, apparatus, product, or process disclosed, or represents that its use would not infringe privately owned rights. Reference herein to any specific commercial product, process, or service by trade name, trademark, manufacturer, or otherwise does not necessarily constitute or imply its endorsement, recommendation, or favoring by the United States Government or any agency thereof. The views and opinions of authors expressed herein do not necessarily state or reflect those of the United States Government or any agency thereof. 


\section{DISCLAIMER}

Portions of this document may be illegible in electronic image products. Images are produced from the best available original document. 
Printed in the United States of America. Available from National Technical Information Service

U.S. Department of Commerce

5285 Port Royal Road, Springfield, Virginia 22161

Price: Printed Copy $\$ 5.00$; Microfiche $\$ 2.25$

This report was prepared as an account of work sponsored by the United States Government. Neither the United States nor the Energy Research and Development Administration, nor any of their employees, nor any of their contractors, subcontractors, or their employees, makes any warranty, express or implied, or assumes any legal liability or responsibility for the accuracy, completeness or usefulness of any information, apparatus, product or process disclosed, or represents that its use would not infringe privately owned rights. 
$\cdots$

ORNL/TM-5261

Contract No. w-7405-eng-26

Reactor Division

A CRITICAL EVALUATION OF HIGH-TEMPERATURE GAS-COOLED REACTORS APPLICABLE TO COAL CONVERSION

I. Spiewak

J. E. Jones Jr.

P. L. Rittenhouse

J. R. Distefano

J. G. Delene

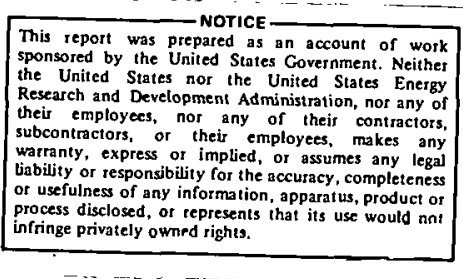

December 1975

NOTICE: This document contains informatinn of a preliminary natire and was prepared primarily for internal use at the Oak Ridge National Laboratory. It is subject to revision or correction and therefore does not represent a final report.

\author{
OAK RIDGE NATIONAL LABORATORY \\ Oak Ridge, Tennessee 37830 \\ operated by \\ UNION CARBIDE CORPORATION \\ for the \\ ENERGY RESEARCH AND DEVELOPMFNT ADMINIGTRATION
}




\section{THIS PAGE}

WAS INTENTIONALLY

LEFT BLANK 
TABLE OF CONTENTS

I. INTRODUCTION I

II. SUMMARY OF APPLICABLE COAL CONVERSION PROCESSES 2

A. Hydrogasification 2

B. Solution Hydrocracking 4

C. Steam Gasification 4

D. Application of Hydrogen from Thermochemical 7 water Splitting

III. DESCRIPTION OF VHTR CONCEPTS 10

A. General Atomic HTGR Prismatic-Core Design 10

B. General Electric Pebble-Bed Reactor 15

C. Westinghouse VHTR 15

D. Discussion of the Three-Vendor Concepts 19

IV. GENERAL CAPABILITIES AND LIMITATIONS OF VHTRS 23

IN THE PROCESS TEMPERATURE RANGE 1400 to $2000^{\circ} \mathrm{F}$

A. Core and Fuels 23

B. Reactor Components 24

C. Materials 27

D. Fission Product Behavior Aspects 53

E. Safety and Environmental Considerations 55

F. Coupling of Reactor and Process: Potential 60 Need for an Intermediate Heat Exchanger

V. ECONOMICS 61

A. Process Heat Cost 61

B. Fuel Cycle Considerations 69

VI. CONCLUSIONS AND RECOMMENDATIONS - R\&D NEEDS 73

A. Conclusions 73

B. Discussion of R\&D Program 76

REFERENCES 80 
A CRITICAL EVALUATION OF HIGH-TEMPERATURE GAS-COOLED REACTORS APPLICABLE TO COAL CONVERSION

\begin{abstract}
A critical review is presented of the technology and costs of very high-temperature gas-cooled reactors (VHTRs) applicable to nuclear coal conversion. Coal conversion processes suitable for coupling to reactors are described. Vendor concepts of the VHTR are summarized. The materials requirements as a function of process temperature in the range 1400 to $2000^{\circ} \mathrm{F}$ are analyzed. Components, environmental and safety factors, economics and nuclear fuel cycles are reviewed. It is concluded that process heat supply in the range 1400 to $1500^{\circ} \mathrm{F}$ could be developed with a high degree of assurance. Process heat at $1600^{\circ} \mathrm{F}$ would require considerably more materials development. While temperatures up to $2000^{\circ} \mathrm{F}$ appear to be attainable, considerably more research and risk were involved. A demonstration plant would be required as a step in the commercialization of the VHTR.
\end{abstract}

\title{
I. INTRODUCTION
}

In the spring of 1974, the Division of Reactor Research and Development (RRD) of the Atomic Energy Commission initiated a program of conceptual studies and evaluations of the application of very high-temperature gas-cooled reactors (VHTRs) to process heat generation. Important elements of this program included conceptual design contracts with General Atomic Corporation (GA), General Electric Company (GE), and Westinghouse Electric Corpuraliun (W) to develop conceptual designs of such reactors to deliver process heat at $1200,1400,1600,1800$ and $2000^{\circ} \mathrm{F} .1,2,3$ Oak Ridge National Laboratory (ORNL) was assigned the mission of evaluating these concepts 4 and their potential application to a number of specific high temperature processes including petroleum refining, petrochemical industry, coal conversion, hydrogen production via thermochemical water splitting, oil shale and tar sands refining and nuclear steelmaking. 
In April 1975, following the creation of Energy Research and Development Administration (ERDA), the ERDA Fossil Energy Division of Coal Conversion and Utilization authorized ORNL to conduct critical evaluations of the application of high-temperature gas-cooled reactors (HTGRs) to coal conversion. This task will reinforce the RRD-sponsored efforts by providing considerably more depth in the coal conversion process evaluation.

The present report has the objective of summarizing the status of VHTR technology applicable to coal conversion. Reliance is placed on the referenced RRD-sponsored studies as well as on publications of foreign programs, notably from the Federal Republic of Germany. A second report will be prepared by ORNL later in the program to cover exploratory studies of selected coal conversion systems using VHTR heat sources.

\section{SUMMARY OF APPLICABLE COAL CONVERSION PROCESSES}

Before evaluating the reactor technology, it is desired to display some of the applicable coal processes and the modes of coupling them to the nuclear heat source.

\section{A. Hydrogasification}

When coal is exposed to hydrogen at elevated temperatures and pressuxes ( 800 to $850^{\circ} \mathrm{C}, 10$ to $\left.100 \mathrm{~atm}.\right)$, there is a strongly exothermic reaction producing methane and other light hydrocarbons. Hydrogen, in turn, can be produced in a methane (light hydrocarbon)-steam reformer heated by the helium coolant of a VHTR. This highly endothermic reaction is carried out usually at 650 to $800^{\circ} \mathrm{C}$.

The important chemical reactions thus are the following:

Hydrogasification

$$
\mathrm{C}+2 \mathrm{H}_{2}=\mathrm{CH}_{4}+20.6 \mathrm{kcal} / \mathrm{mole} \mathrm{C}
$$

Steam Reforming

$$
\begin{aligned}
& \mathrm{CH}_{4}+\mathrm{H}_{2} \mathrm{O}(\mathrm{v})=\mathrm{CO}+3 \mathrm{H}_{2}-49 \mathrm{kcal} / \mathrm{mole} \mathrm{C} \\
& \mathrm{CO}+\mathrm{H}_{2} \mathrm{O}(\mathrm{v})=\mathrm{CO}_{2}+\mathrm{H}_{2}+9.9 \mathrm{kcal} / \mathrm{mole} \mathrm{C}
\end{aligned}
$$

Shift

Depending on the desired product, this conversion process can be designed for net production of methane, syngas $\left(\mathrm{H}_{2}+\mathrm{CO}\right)$ or hydrogen.

In the most straightforward version of this process as proposed by the Germans ${ }^{5,6}$ (Fig. 1), coal is dried and then gasified with the hydrogen stream produced in the methane steam reformer. The gasified coal is purified (by $\mathrm{H}_{2} \mathrm{O}, \mathrm{H}_{2} \mathrm{~S}$ and $\mathrm{CO}_{2}$ removal steps), about one-half becomes product 
ORNL-DWG 75-14759

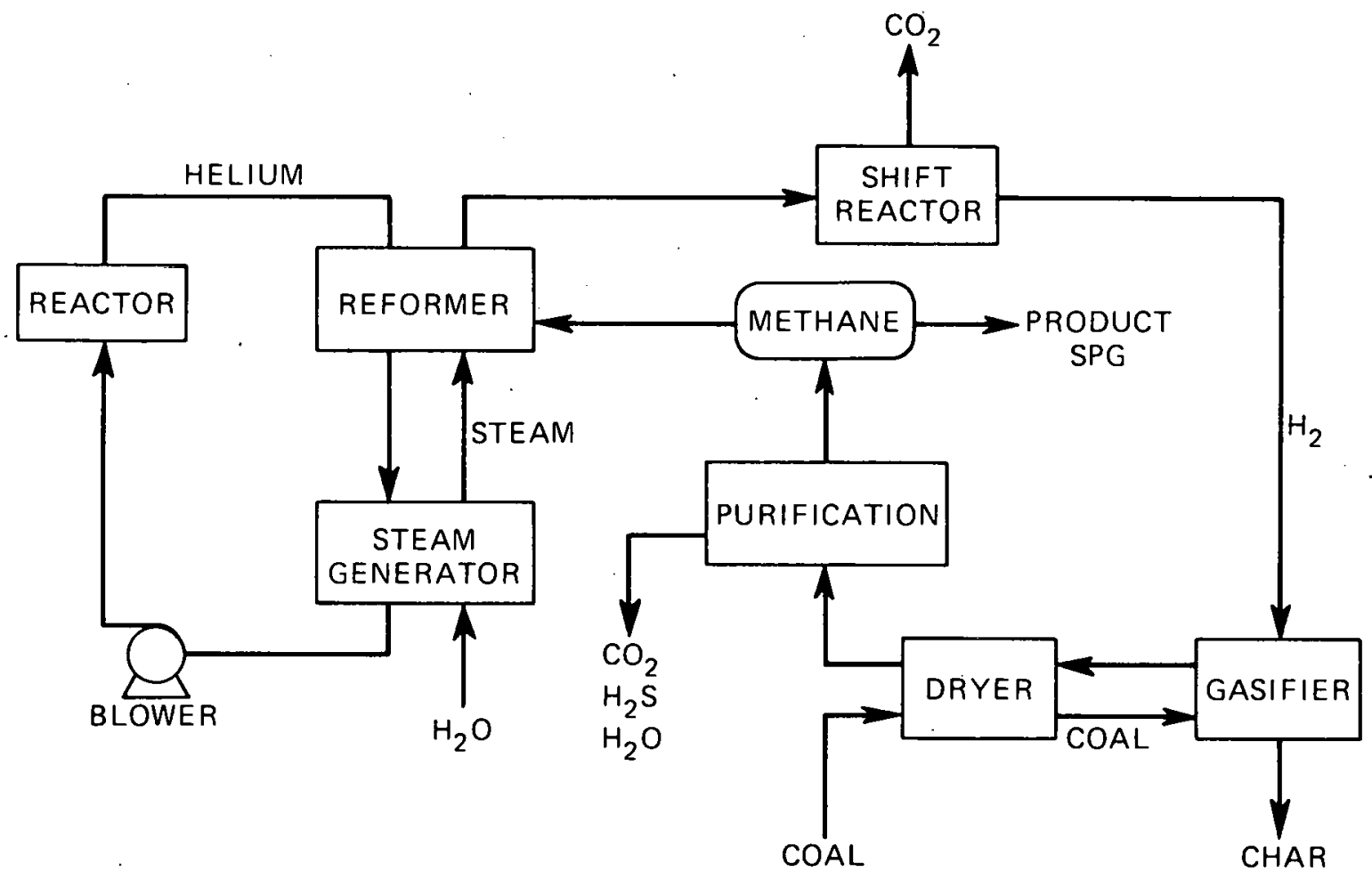

FIGURE 1. Hydrogasification of Coal Using VHTR 
synthetic pipeline gas and one-half is recycled to the reformer. About $40 \%$ of the coal heating value remains in residual char for which an economic use must be found.

As the temperature is increased and the pressure decreased, the methane reforming reaction goes more strongly toward completion. Table 1 (from reference 1) shows the effect of process temperature on the methane conversion. The conversion increases rapidly up to about $1400^{\circ} \mathrm{F}$, and increases slowly thereafter.

There is a corresponding increase in the reformer heat duty as the process temperature is increased (Table 2, from reference 1). Since the total heat output of the reactor in Table 2 remains constant as temperature is increased, the heat duty of the steam generator is reduced with increased temperature; heat duty of the reformer and steam generator are equal at about $1500^{\circ} \mathrm{F}$ maximum process temperature.

\section{B. Solution Hydrocracking}

The General Atomic/Stone \& Webster (GA/S\&W)process ${ }^{7}$ (Fig. 2) is a variation of the hydrogasification process where coal is powdered, dried, and dissolved in coal liquids prior to the solution hydrocracking step. The hydrogen for the hydrocracking is obtained, as before, from the heliumheated light hydrocarbon reformer. Depending on the ratio of recycle hydrocarbon to product and the product refining steps, the product mix can be predominantly coal liquids, pipeline gas, syngas $\left(\mathrm{CO}+\mathrm{H}_{2}\right)$ or hydrogen.

The coal-liquids technology used here is similar to that used for making solvent refined coal or for other coal liquefication systems. It is anticipated that the coal heating value remaining in residential solids will be in the ranqe of 10 to $20 \%$ of the oriqinal or feed coal heating value.

\section{Steam Gasification ${ }^{8}$}

Coal reacts with steam at elevated temperatures in a strongly endothermic reaction. The products of the reaction (syngas) can be converted to desired products such as methane or hydrogen. The important chemical reactions are the following:

$$
\begin{array}{ll}
\text { Gasification } & \mathrm{C}+\mathrm{H}_{2} \mathrm{O}(\mathrm{v})=\mathrm{CO}+\mathrm{H}_{2}-28.4 \mathrm{kcal} / \mathrm{mole} \mathrm{C} \\
\text { Shift } & \mathrm{CO}+\mathrm{H}_{2} \mathrm{O}(\mathrm{v})=\mathrm{CO}_{2}+\mathrm{H}_{2}+9.9 \mathrm{kcal} / \mathrm{mole} \mathrm{C} \\
\text { Methanation } & \mathrm{CO}+3 \mathrm{H}_{2}=\mathrm{CH}_{4}+\mathrm{H}_{2} \mathrm{O}+49 \mathrm{kcal} / \mathrm{mole} \mathrm{C}
\end{array}
$$


Table 1

Methane Reformer Conversion Data

\begin{tabular}{llccc}
\hline $\begin{array}{l}\text { Maximum } \\
\text { process } \\
\begin{array}{c}\text { temp. } \\
\left({ }^{\circ} \mathrm{F}\right)\end{array}\end{array}$ & $\begin{array}{c}\text { Entering } \\
\text { process } \\
\text { temp. } \\
\left({ }^{\circ} \mathrm{F}\right)\end{array}$ & $\begin{array}{c}\text { Steam-gas } \\
\text { ratio }\end{array}$ & $\begin{array}{c}\text { Pressure } \\
(\text { psia) }\end{array}$ & $\begin{array}{c}\text { Hydrocarbon } \\
\text { conversion } \\
(8)\end{array}$ \\
\hline 1200 & 1050 & $4.5: 1$ & 300 & 27.9 \\
1400 & 1050 & $4.5: 1$ & 300 & 57.8 \\
1600 & 1050 & $3.0: 1$ & 400 & 66.9 \\
1800 & 1050 & $1.5: 1$ & 500 & 71.3 \\
2000 & 1050 & $1.5: 1$ & 600 & 82.6 \\
\hline
\end{tabular}

Table 2

Distribution of Heat Between Reformer and Steam Generator (a)

\begin{tabular}{lccc}
\hline $\begin{array}{l}\text { Maximum } \\
\text { process } \\
\text { temp. } \\
\left({ }^{\circ} \mathrm{F}\right)\end{array}$ & $\begin{array}{c}\text { Entering } \\
\text { process } \\
\text { temp. } \\
\left({ }^{\circ} \mathrm{F}\right)\end{array}$ & Heat Duty & $\left(10^{9}\right.$ Btu/hr $)$ \\
\hline 1200 & 1050 & 2.50 & $\begin{array}{c}\text { Steam } \\
\text { generator }\end{array}$ \\
1400 & 1050 & 4.82 & 8.00 \\
1600 & 1050 & 5.84 & 5.68 \\
1800 & 1050 & 6.38 & 4.66 \\
2000 & 1050 & 7.45 & 4.12 \\
\hline
\end{tabular}

(a) Core thermal output $=3000 \mathrm{MW}(t)$, pumping powor ic approusimatcly $80 \mathrm{MW}(t)$ for all cases. 


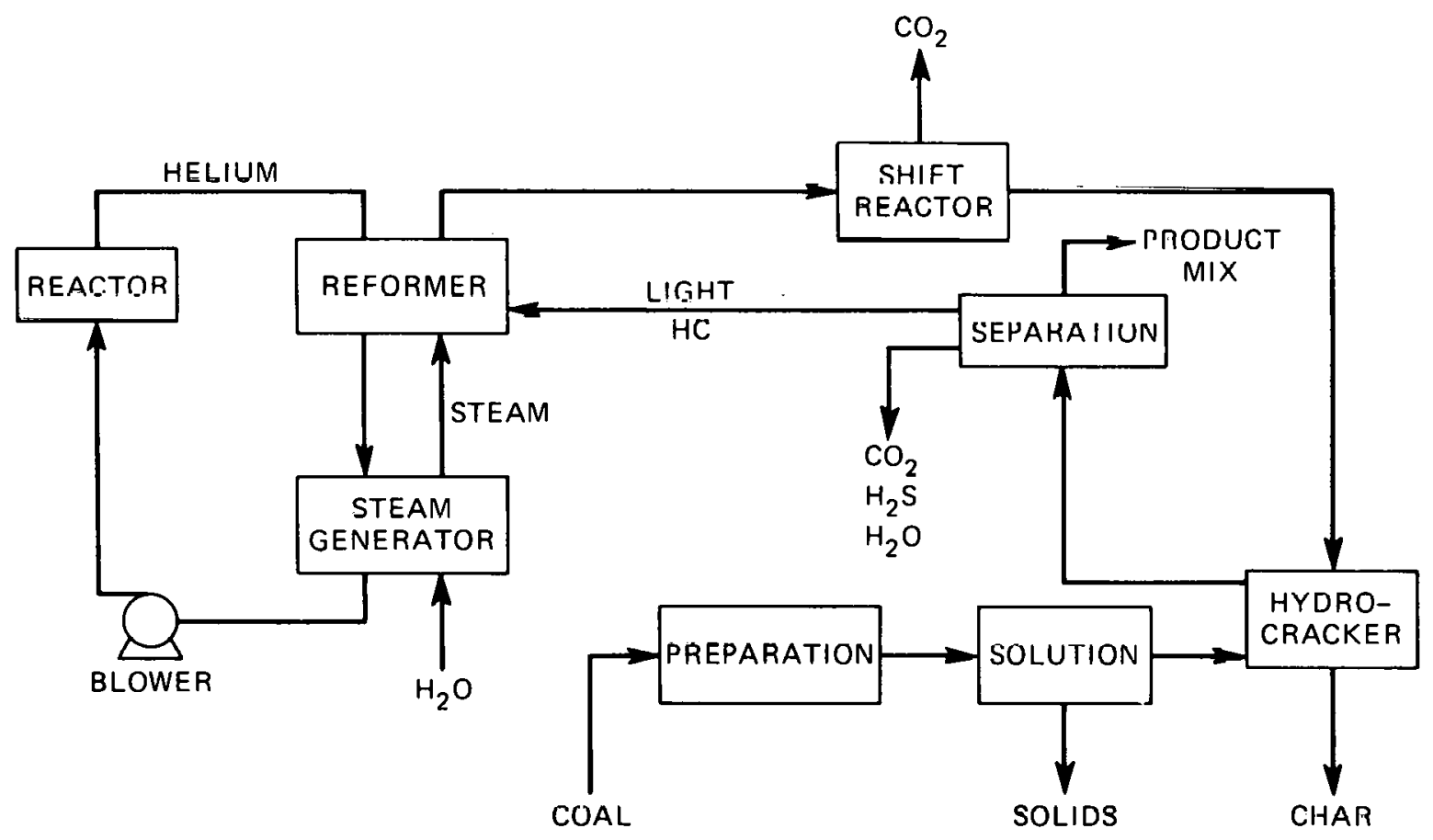

FIGURE 2. Solution Hydrocracking of Coal Using VHTR 
The steam-carbon reaction rates (Fig. 3) begin at about $600^{\circ} \mathrm{C}$ for lignite and $700^{\circ} \mathrm{C}$ for hard coal. The Germans propose to operate a lignite steam-gasifier at $660^{\circ} \mathrm{C} i^{9}$ this gasifier would be a steam-fluidized bed heated internally with helium tubes. Figure 4 is a schematic of this system.

This system requires an intermediate heat exchanger (IHX) between the reactor and the gasifier because it is not believed practical to provide maintenance for a coal gasifier in the primary coolant circuit. Furthermore, the steam gasification reaction uses a smaller fraction of the VHTR energy output than does the methane reformer of the earlier processes; there is a significant amount of by-product electric power in the German scheme.

The steam gasification process leaves a residue of char, according to United Kingdom sources; ${ }^{10}$ the UK paper cites 750 to $850^{\circ} \mathrm{C}$ as reasonable temperatures for lignite gasification with $925^{\circ} \mathrm{C}$ recommended for "high carbon conversion." The corresponding temperature for hard coal is given as 1050 to $1100^{\circ} \mathrm{C}$.

For the steam gasification process to be practical, a very high-temperature heat source would have to be developed and/or a practical catalyzed low-temperature coal reaction developed.

D. Application of. Hydrogen from Thermochemical Water splitting

A high-temperature reactor may provide process energy for splitting water into hydrogen and oxygen. This cannot be achieved in a simple onestep reaction at practical temperatures; instead, many potential chairs have been investigated. An example, proposed by Westinghouse, ${ }^{3}$ uses the following steps:

$$
\begin{aligned}
& \mathrm{SO}_{2}(g)+(2+X) \mathrm{H}_{2} \mathrm{O}(l) \text { electrolytic } \\
& \mathrm{H}_{2} \mathrm{SO}_{4} \cdot \mathrm{XH}_{2} \mathrm{O}+\mathrm{H}_{2}(g) \\
& \mathrm{H}_{2} \mathrm{SO}_{4} \cdot \mathrm{XH}_{2} \mathrm{O} \stackrel{\text { thermal }}{\longrightarrow} \mathrm{H}_{2} \mathrm{SO}_{4}(l)+\mathrm{XH}_{2} \mathrm{O}(g) \\
& \mathrm{H}_{2} \mathrm{SO}_{4}(l) \stackrel{\text { thermal }}{\longrightarrow} \mathrm{H}_{2} \mathrm{O}(g)+\mathrm{SO}_{3}(g) \\
& \mathrm{SO}_{3}(g) \stackrel{\text { thermal }}{\longrightarrow} \mathrm{SO}_{2}(g)+1 / 2 \mathrm{O}_{2}(g)
\end{aligned}
$$

where $(g)$ and $(l)$ refer respectively to the gaseous and liquid state. 


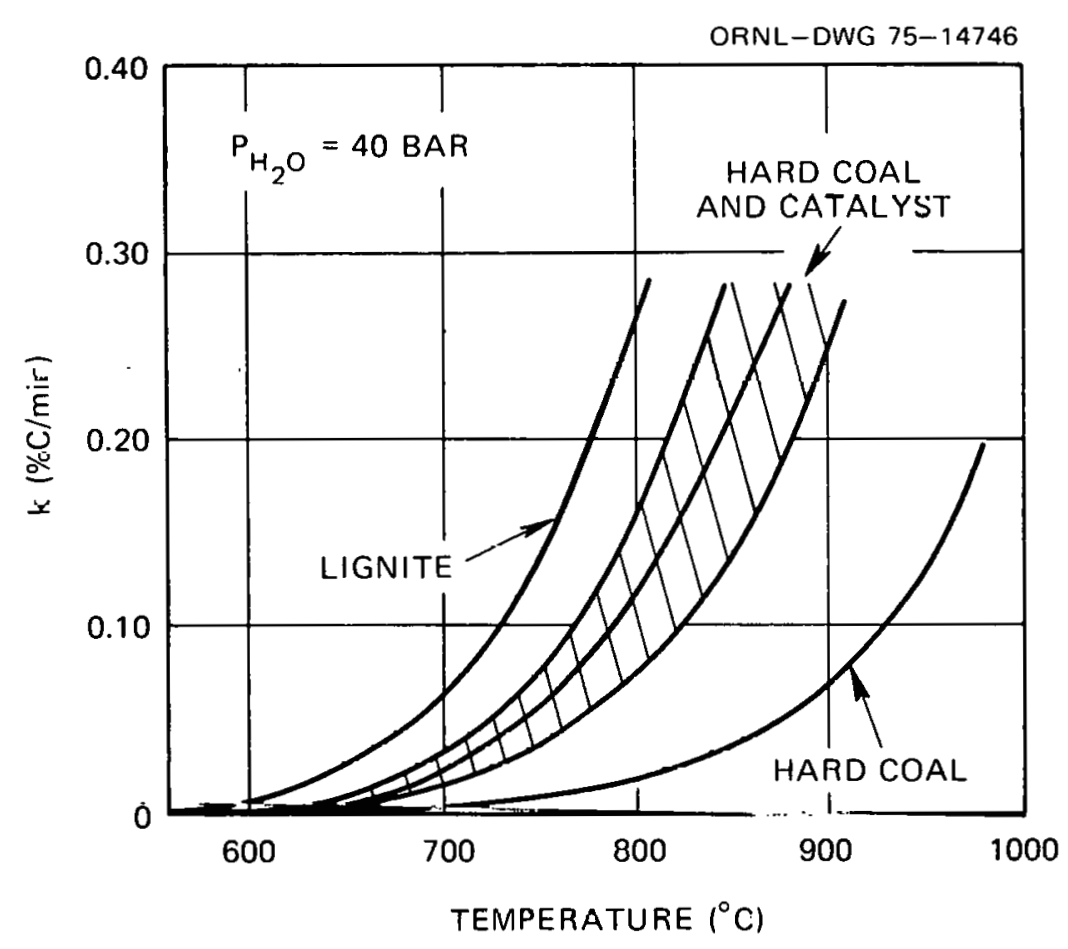

FIGURE 3. Steam-Carbon Reaction Rates for Lignite, Hard Coal, and Hard Coal with Catalyst 
ORNL-DWG 75-14757

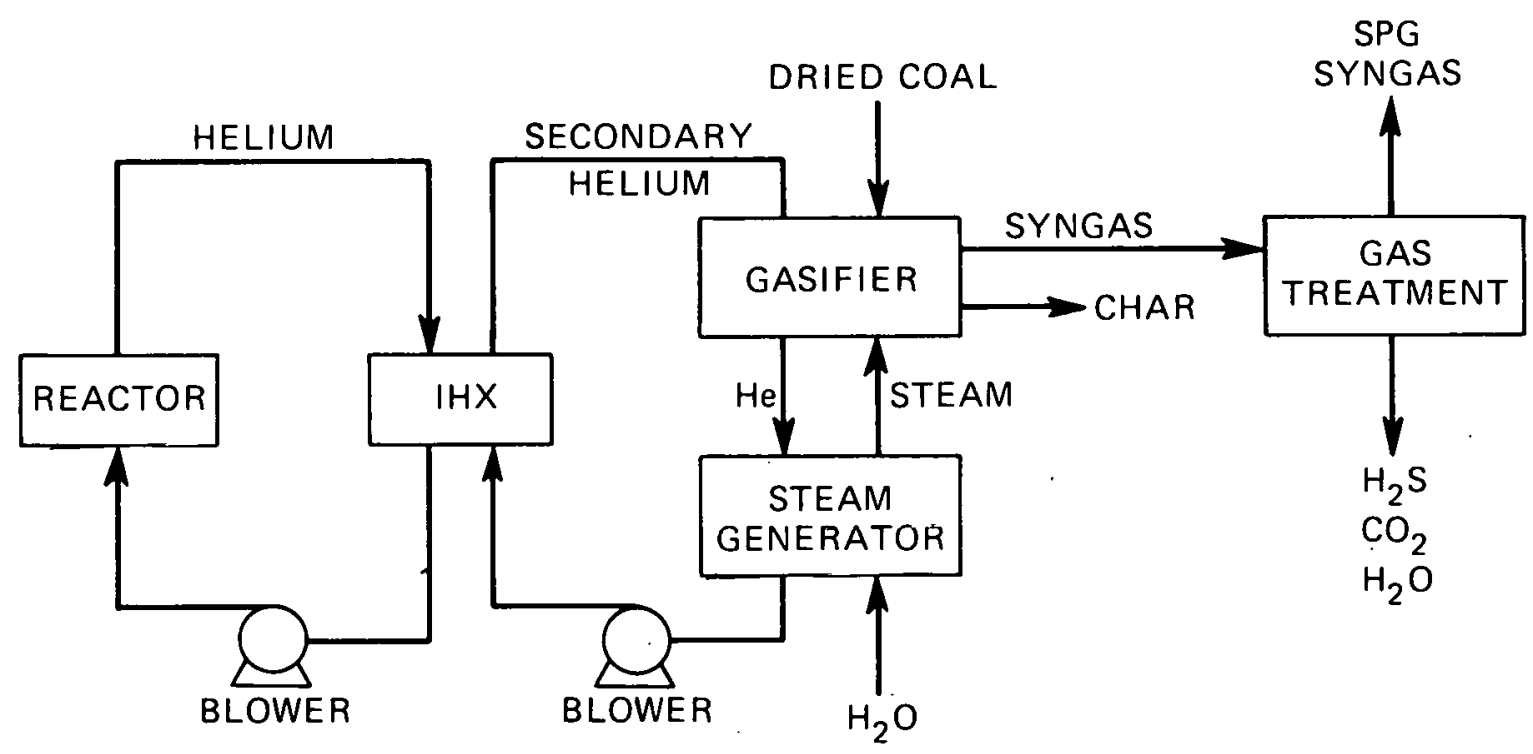

FIGURE 4. Lignite-Steam Gasifier Using VHTR 
The products of water splitting have many uses. One of these could be for coal conversion in a scheme such as in Fig. 5.

Efficient water splitting requires process temperatures of $1600^{\circ} \mathrm{F}$ or higher.

\section{DESCRIPTION OF VHTR CONCEPTS}

Several VHTR concepts have been evolved in the U.S. and abroad. The three vendor design studics ${ }^{1,2,3}$ present features which encompass most of the available technology. These concepte, each supplying $3000 \mathrm{MW}$ of heat, are described in the following sectiuns.

The VHTRs are thermal reactors utilizing helium as coolant and having all-ceramic cores composed of graphite moderator and enriched uraniumthorium fuel. This combination has enabled the gas-cooled reactor to develop coolant outlet temperatures far higher than those of other reactor systems. For production of electricity, these temperatures permit the production of high-temperature, high-pressure steam, leading to high cycle efficiency. Similar designs, at more elevated temperatures, are believed to be useful for generating process heat for coal conversion.

\section{A. General Atomic (GA) HTGR Prismatic-Core Design}

General Atomic has developed the High-Temperature Gas-Cooled Reactor (HTGR) as a commercial steam-generating reactor for use by utilities. The Peach Bottom Reactor [115 MW(t), 40 MW(e)] was operated successfully by Philadelphia Electric Company from June 1967 to Octuber 1974 and pruvel the feasibility of the concept. $\bar{A}$ somewtiat simllas system, tho Dragen [20 MW(t)], was developed independently in Europe, and has operated from 1965 to the present. GA has built a much lasyer HTGR at Fort st. Vrain [842 MW(t), $330 \mathrm{MW}(e)]$ which has thus far been operated at low power levels. In addition, GA sold four commercial units in the size range 770 to 1160 MW(e), which were scheduled to be started up in the early 1980s. These plants were 


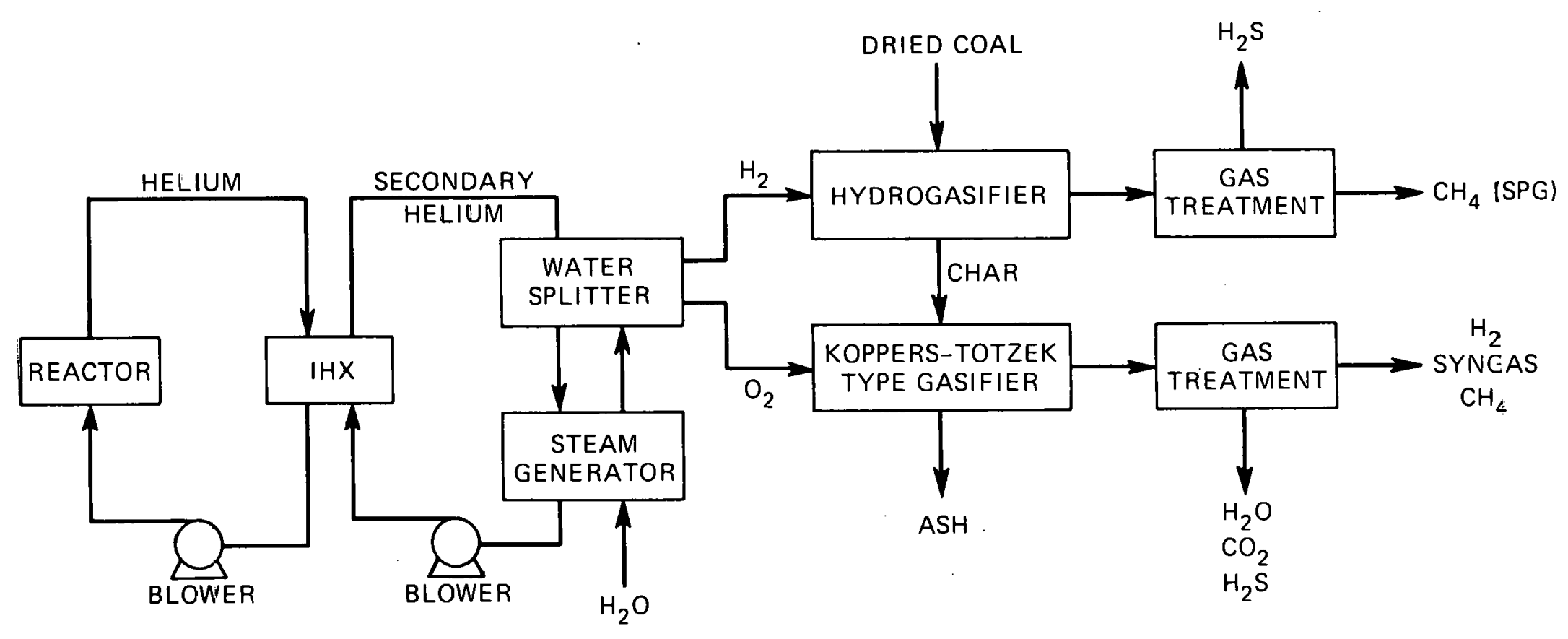

FIGURE 5. Coal Conversion with $\mathrm{H}_{2}$ and $\mathrm{O}_{2}$ from water Splitting using VHTR 
canceled in September and October 1975 because of financial-price problems. It was announced also that GA was temporarily withdrawing from commercial sales of HTGRs but planned to continue development.

The standard commercial HTGR is modified for process heat purposes by placing a process heat exchanger in series with and upstream of the steam generator. As in other current HTGR designs, all the primary system components are contained in one large prestressed concrete reactor vessel (PCRV) because of the advantages offered by this form of construction. Steam-methane reforming was selected by GA as a typical high-temperature process; and the reformer was assumed to be located within the PCRV.

The addition of a helium-heated steam-methane reformer in a wall cavity of the PCRV is shown in Fig. 6. This reformer 1s similar in size to the steam generaturs of the $3000 \mathrm{M}(r)$ reactor, and it san he installed and removed in the same manner as they are.

The process heat HTGR operates as follows. Helium flows downward through the core, where it is heated to a temperature about $200^{\circ} \mathrm{F}$ above the required process temperature. The helium passes through one of the radial ducts going to the reformer and then passes upward through the reformer cavity. Heat is transferred through the reformer tube walls to the steam-methane mixture. The hclium then flows through the circumferential duct (not shown in Fig. 6) to the adjacent steam generator cavity, whcre it passes downward over the steam generator cuils. It next passes upward around the steam generator and into the helium circulator, where it is compressed. It then passes through the upper horizontal duct and back into the core.

An overall process flow diagram is shown in Fiy. 7 for a helinm nutlet temperature of $1620^{\circ} \mathrm{F}$. The steam-methane mixture is preheated betore it enters the reformer. It passes through the reformer, where $\mathrm{H}_{2}, \mathrm{CO}$, arid $\mathrm{CO}_{2}$ are formed in the presence of a nickel catalyst with the adiitinn of heat from the helium. Reformer outlet conditions are approximately $1400^{\circ} \mathrm{F}$. Downstream processing of this mixture will shift the co plus $\mathrm{H}_{2} \mathrm{O}$ to $\mathrm{H}_{2}$ and $\mathrm{CO}_{2}$ and scrub out the $\mathrm{CO}_{2}$, leaving $\mathrm{H}_{2}$, the remainder being $\mathrm{CH}_{4}{ }^{.}$The once-through steam generator takes feedwater and produces 2500-psig steam at $955^{\circ} \mathrm{F}$, the same as in the conventional HTGR.

The GA study was based on the assumption that an intermediate heat exchanger (IHX) would not be required. If an IHX is required, reactor exit 


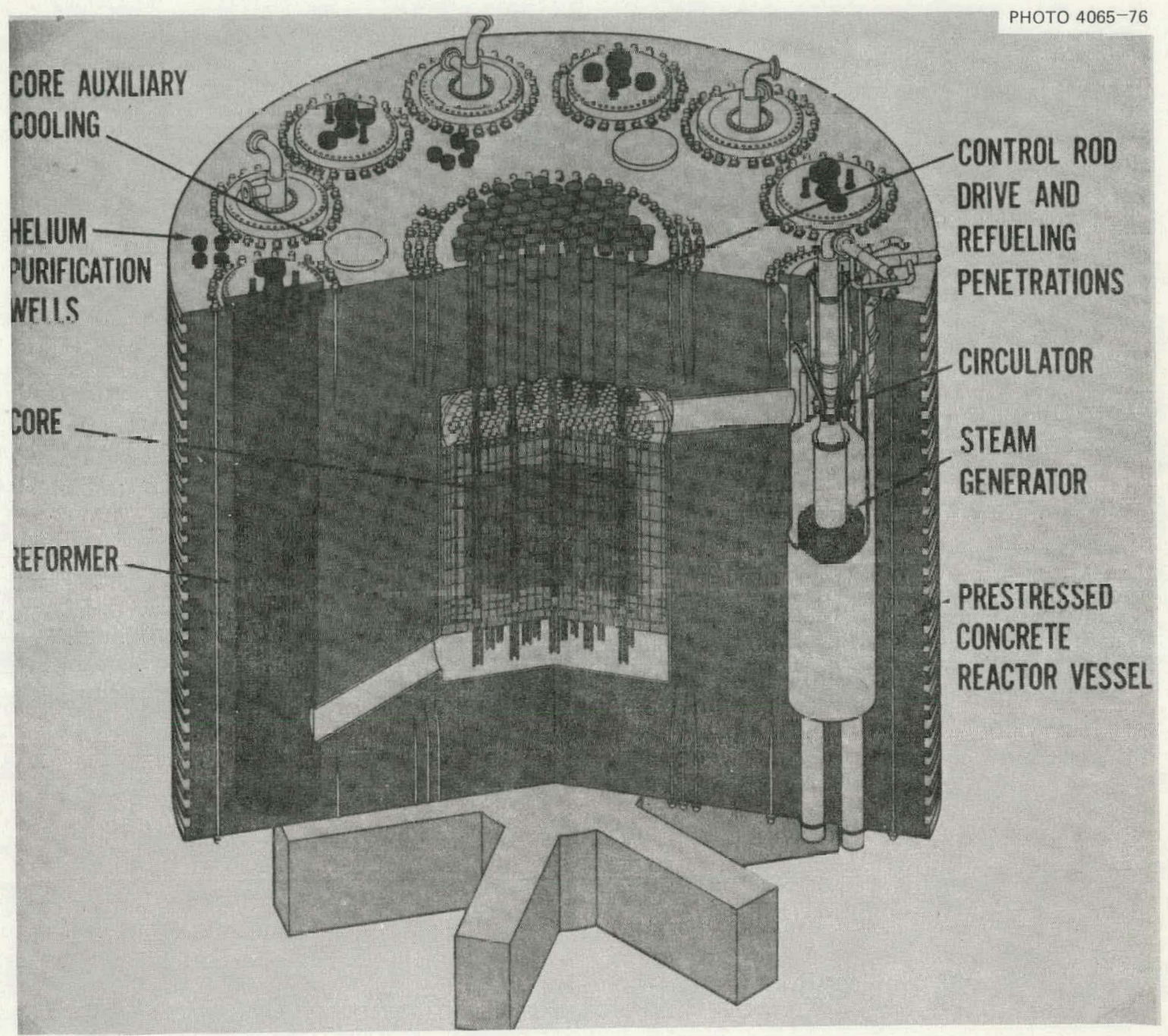

FIGURE 6. Process Heat HTGR 


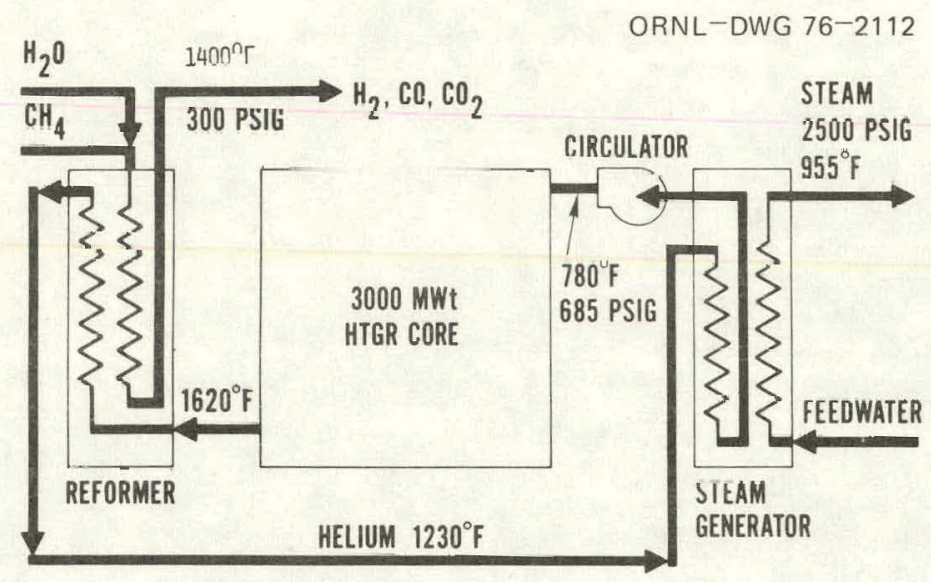

FIGURE 7. Helium Heat Transfer Loop 
helium temperatures would have to be increased well above $1620^{\circ} \mathrm{F}$ to reach $1400^{\circ} \mathrm{F}$ maximum process temperature.

In the standard HTGR, helium leaves the core at about $1400^{\circ} \mathrm{F}$. An Office of Coal Research study of the HTGR ${ }^{7}$ assumed temperatures similar to those of Fig. 7. The VHTR study ${ }^{1}$ considered core outlet temperatures of $1400^{\circ} \mathrm{F}$ to $2200^{\circ} \mathrm{F}$ to achieve the desired range of 1200 to $2000^{\circ} \mathrm{F}$ maximum process temperature.

B. General Electric (GE) Pebble-Bed Reactor (PBR)

The Pebble-Bed Reactor, developed by Kernforschungsanlage (KFA) Jilich, ${ }^{11}$ differs from the HTGR primarily by having the fuel contained in graphite moderator balls. These balls are loaded into and withdrawn from the reactor during operation. The PBR concept was selected by GE for their VHTR design. 2

KFA has built and is operating the Arbeitsgemeinschaft Versuchsreaktor (AVR) [46 MW(t), $15 \mathrm{MW}(e)]$, an experimental steam-generating PBR. The AVR has operated at a helium core outlet temperature of $950^{\circ} \mathrm{C}\left(1742^{\circ} \mathrm{F}\right)$ since February 1974. A larger PBR, The High Temperature Reactor (THTR) [768 MW(t), $300 \mathrm{MW}(\mathrm{e})]$, is under construction and scheduled for 1978 operation. This steam generating reactor will have a helium outlet temperature of $750^{\circ} \mathrm{C}$, in the same range as commercial HTGRs.

The GE PBR places all primary system components into a PCRV (Fig. 8). Primary helium coolant flows downward through the core and exits into five loops, each containing an intermediate heat exchanger (IHX) and a steam generator (SG). A secondary helium stream is heated in the IHX and transported out of the reactor vessel to an external process heater, which GE assumes to be a methane steam reformer. The primary coolant, after leaving the IHX, is cooled down to $250^{\circ} \mathrm{C}$ in the SG and then compressed into the core inlet plenum. See. Fig. 9.

\section{Westinghouse (W) $\mathrm{VHTR}^{3}$}

This concept contains a number of novel features. The reactor and its coolant loops are contained within a multi-cavity prestressed cast iron reactor vessel (PCIV), as shown in Fig. 10. The reactor core is located within the vessel's central cavity. The vessel walls contain twelve smaller vertical cavities, or pods, in which are five high temperature intermediate heat exchangers and circulators, five gas turbines 


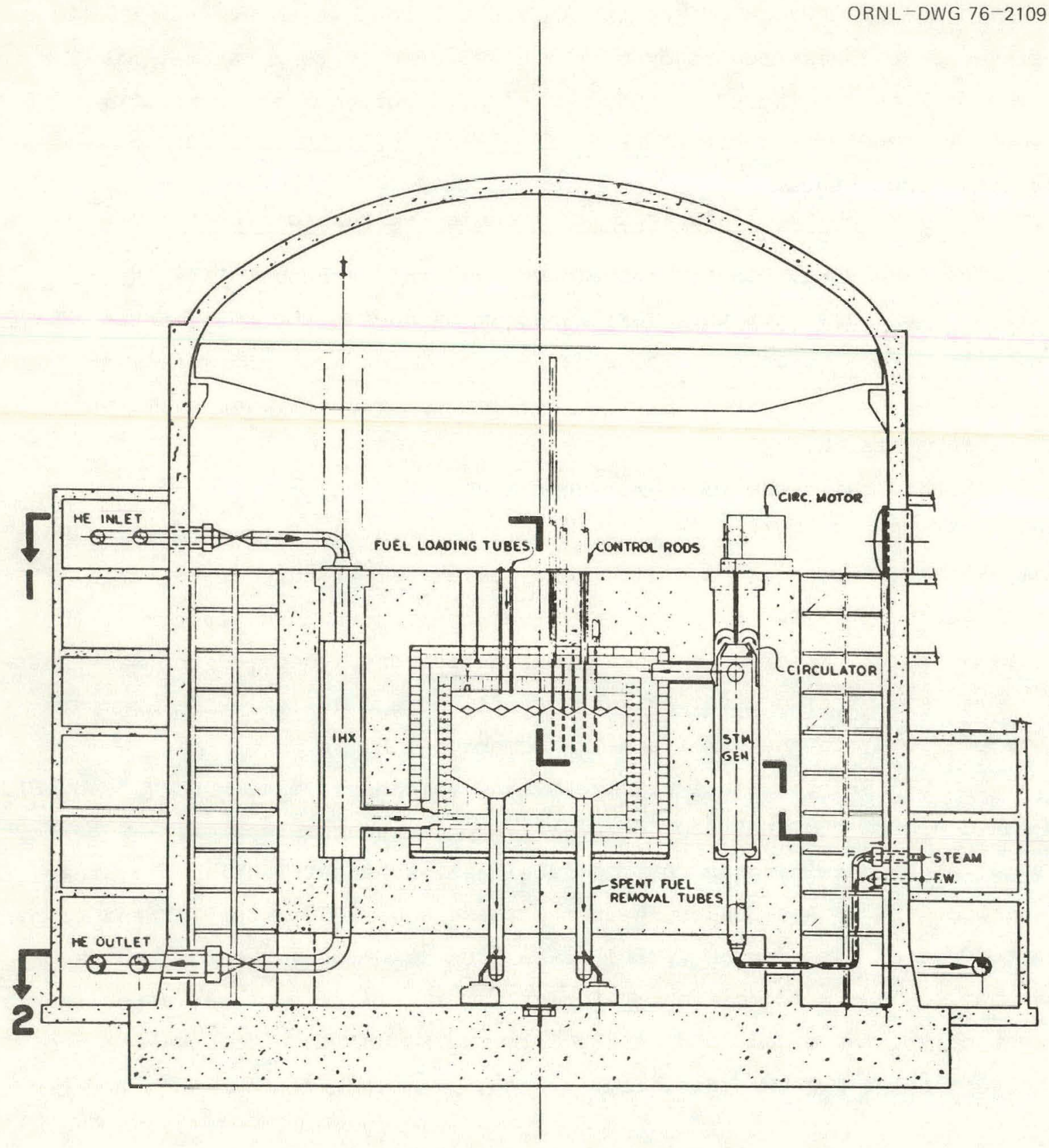

SECTION A-A -

FIGURE 8. Process Heat Pebble-Bed Reactor 


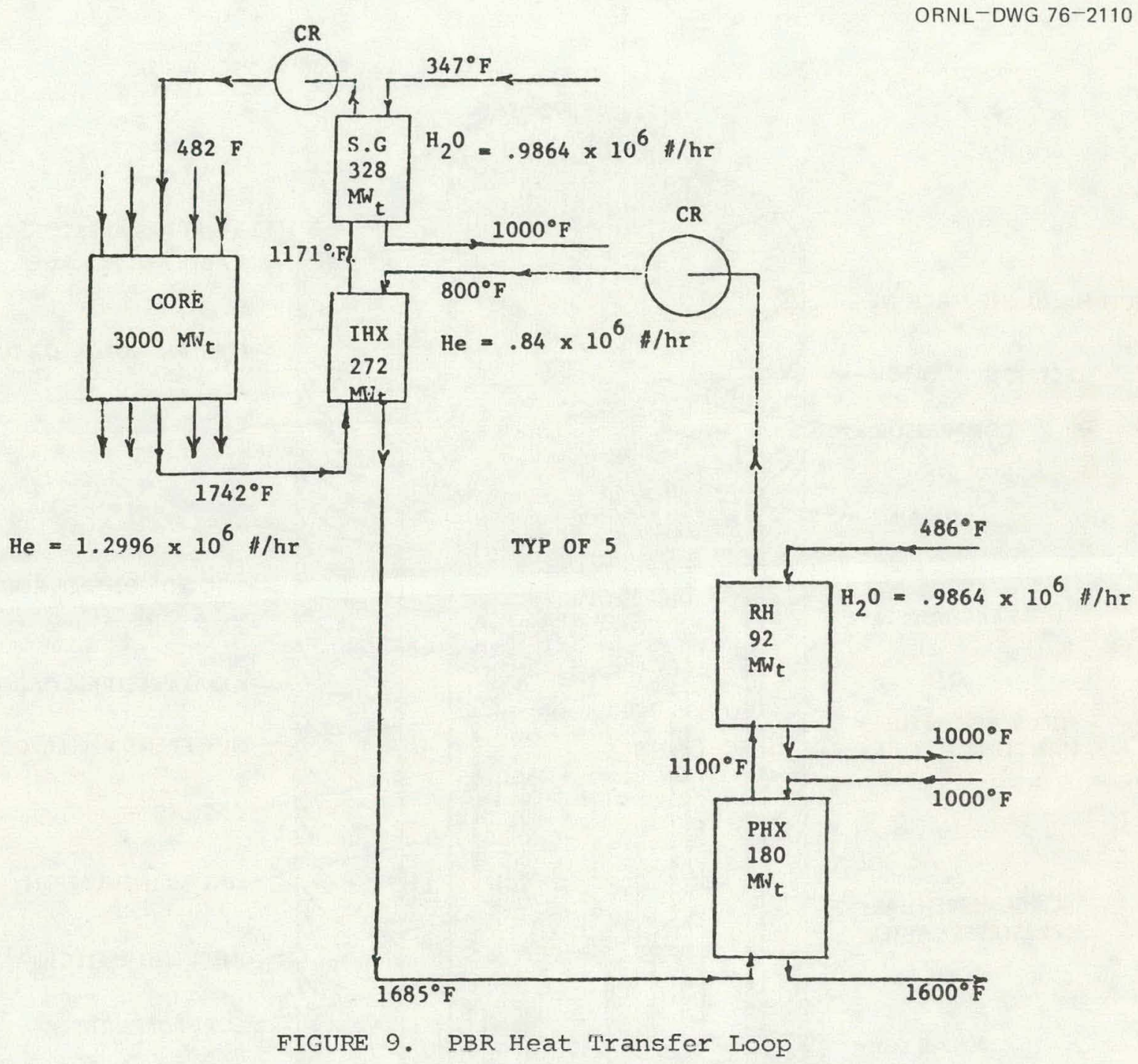




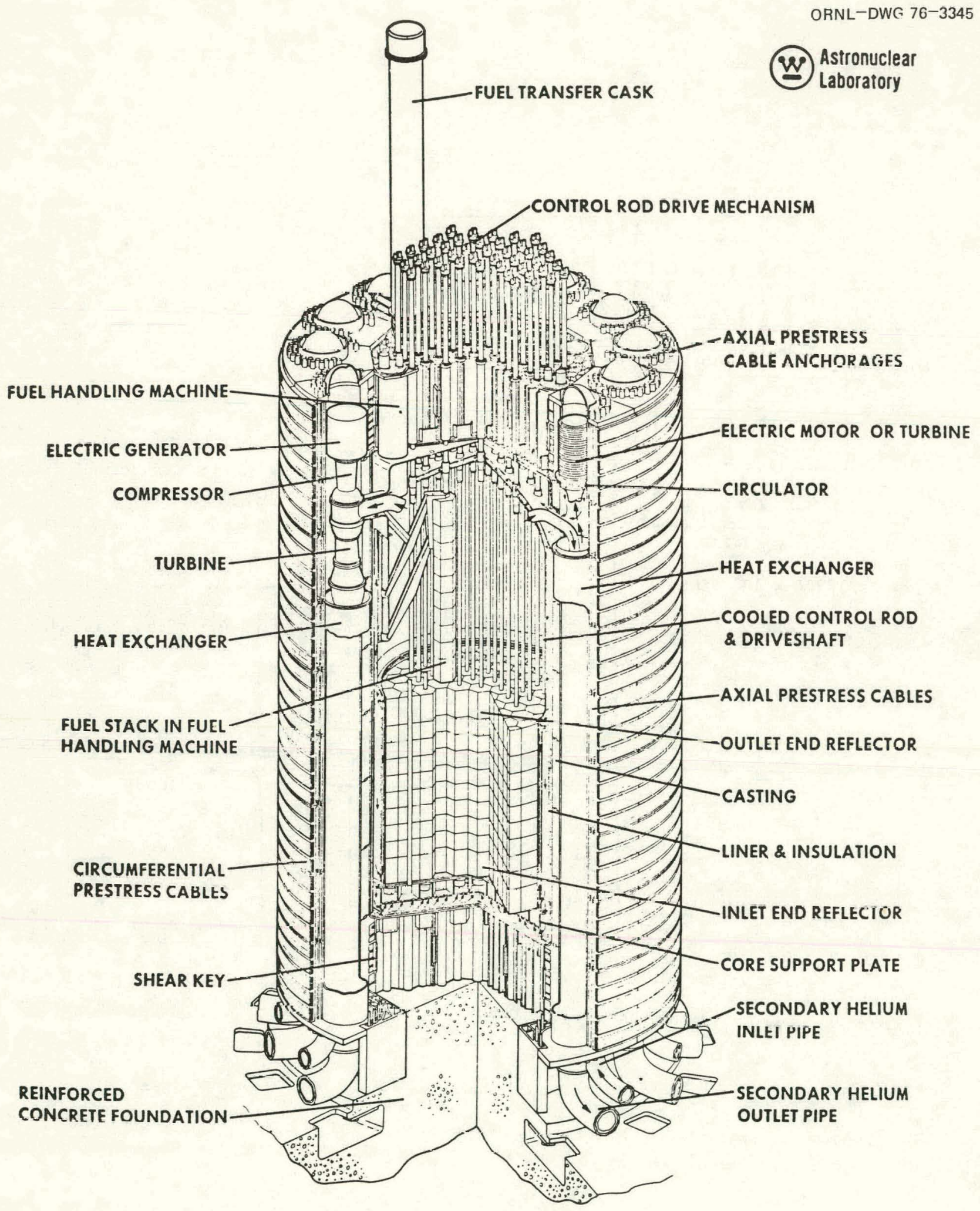

FIGURE 10. Westinghouse Process Heat VHTR 
and low temperature intermediate heat exchangers, and two auxiliary cooling systems for shutdown and emergency cooling of the reactor. Reactor helium coolant enters and discharges from the pods through coaxial piping at the upper end of the cavity, while the intermediate loop, or secondary, helium coolant is introduced and leaves through the bottom of the pod. The PCIV has a continuous internal steel liner to act as a primary coolant boundary and leak-tight membrane. A thermal barrier and insulation system is used to limit the temperature of the liner and minimize the heat loss to the PCIV. A cooling system circulates water through the walls of the PCIV to remove the heat deposited in the vessel. The PCIV is fabricated as a series of cast iron blocks assembled together around a welded steel liner. Prestress cables are wound around the external cylindrical surface, imposing a high compressive stress on the vessel assembly in the radial and tangential directions and preventing the castings from separating under the internal gas pressure forces. Similarly, axial cables running longltudinally through ports provided in the castings maintain a high compressive stress in the axial direction and carry the axial pressure loads. The fuel is contained in extruded graphite elements in direct contact with the primary helium coolant stream.

As seen in Fig. 10, the cool helium is forced through the upper portion of the reactor cavity, then down the annular regions near the PCIV, up through the core to the gas turbines and IHXs, and finally to the compressor. Figure 11 shows a flow schematic. The process heat exchangers and the gas turbine-generators provide energy for a thermochemical watersplitting process hased on the sulfur cycle.

\section{Discussion of the Three-Vendor Concepts}

All three-vendor concepts appeared to have potential to achieve process temperatures in the range 1400 to $2000^{\circ} \mathrm{F}$. The GE concept has the most applicable operational background in that the AVR has been operated successfully at $950^{\circ} \mathrm{C}$ for cxtended periods. $G A$, on the other hand, has developed technology applicable to $3000 \mathrm{MW}(t)$ designs and has the broadest technological base. The Peach Bottom outlet temperature was only $715^{\circ} \mathrm{C}$; however, it appears likely that the HTGR technology would be applicable to more elevated temperatures as well. The $\underline{W}$ concept does not have a 


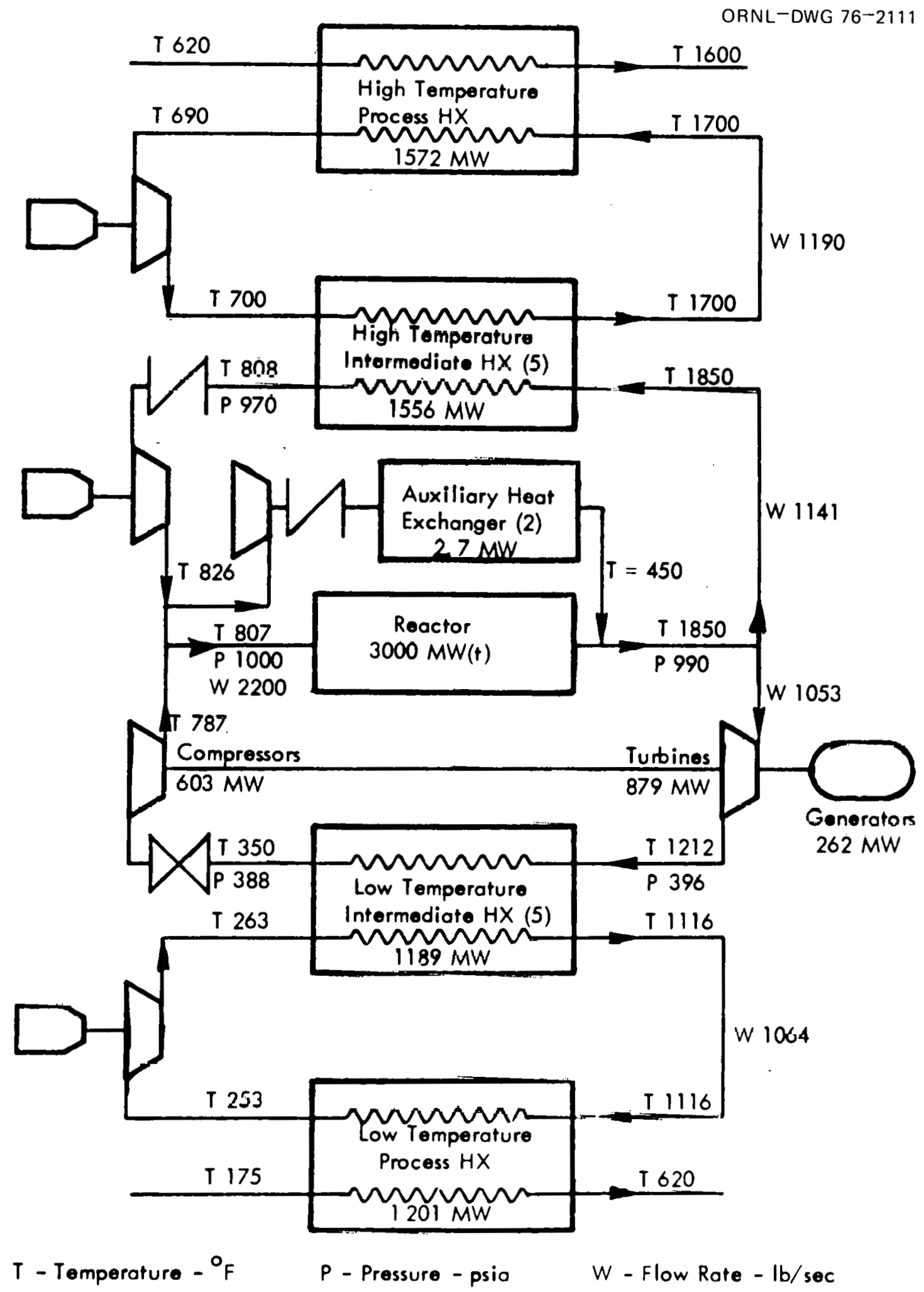

FIGURE 11. Westinghouse Heat Transfer Loop 
commercial technological base comparable to the other two concepts; more development would be required.

The GA design was the only one not to use an IHX, but stated that the need for an IHX had not been ruled out. GE included an IHX, with implications of some hope that additional studies would show that it could be eliminated. W made a case for the necessity of the IHX. As there does not appear to be any basic design feature or innovation which would allow one concept only to use the direct system, it is assumed that this difference at the present time is one of vendor philosophy. Further analysis of reactor safety and of radioactivity transport is required to establish whether the IHX can be eliminated for some range of process choices; the issue is discussed in more detail in Section IVD. - Fission Product Behavior Aspects.

Table 3 presents a tabulated comparison of features of the three concepts. The process temperature of each of these reference concepts is indicative of the historical development of the concept. The HTGR has evolved from a very strong technology program focused on steam generation. The lowest temperature required for a reasonable process efficiency, $1400^{\circ} \mathrm{F}$, has been chosen to take minimum extrapolation of existing components and technology. The PBR concept is based on the technology of the AVR scaled up to commercial size; the process temperature selection of $1500^{\circ} \mathrm{F}$ is a $\operatorname{logi-}$ cal consequence of the AVR helium outlet temperature of $950^{\circ} \mathrm{C}$, assuming that the heat transport systems can be developed. The $\underline{W}$ concept is derived from the very advanced Nerva technology, which operated for short times at extremely high temperatures. The water-splitting process coupled to the $\underline{W}$ reference design requires at least $1600^{\circ} \mathrm{F}$ to proceed at reasonable efficiency. 
Table 3

Comparisor of the Three-Vendcr Concepts

\begin{tabular}{|c|c|c|c|}
\hline & General Atomic & Gereral Electric & Westinghouse \\
\hline $\begin{array}{l}\text { Easis of very high temperature suclear } \\
\text { reactor design }\end{array}$ & Moćsfication of FTGR sencept & $\begin{array}{l}\text { Pebble bed concept based on German } \\
\text { technology }\end{array}$ & $\begin{array}{l}\text { Prismatic fuel concept based on } \\
\text { nuclear rocket technology }\end{array}$ \\
\hline Reactor core type & $\begin{array}{l}\text { Hexagonal graphile tlocks con- } \\
\text { taini.rg separate coo:ant and } \\
\text { fuel passages, sollid cylin- } \\
\text { drical fuel rods }\end{array}$ & $\begin{array}{l}\text { Pebble bed core } \\
\text { Graphitee sphere fuel element }\end{array}$ & $\begin{array}{l}\text { Fexagonal graphite blocks, } \\
\text { hollow cylincirical fuel rods } \\
\text { with central coolant channel }\end{array}$ \\
\hline Reactor coolant & He:-ium & Jelium & Helium \\
\hline Reference thermal power & $3000 \mathrm{MW}(t)$ & $3000 \mathrm{MW}(\mathrm{t})$. & $3 \supset 00 \mathrm{MW}(\mathrm{t})$ \\
\hline Pressure vessel concept & $\begin{array}{l}\text { Prestressed concreze reactor } \\
\text { ressel }\end{array}$ & Prestressed concrete reactor vess $\epsilon: 1$ & $\begin{array}{l}\text { Prestressed cast iron reactor } \\
\text { vessel }\end{array}$ \\
\hline Fuel composition & 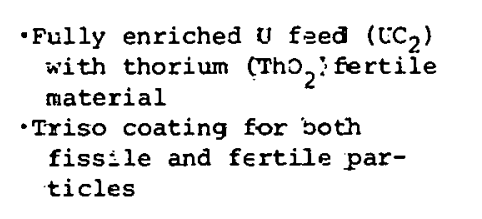 & $\begin{array}{l}\text { - Low enriched }(9.018){ }^{235} \text { U fuel } \\
\text { - Uranium-thorium fuel alternate } \\
\text { - Triso coated } \mathrm{JO}_{2} \text { fuel particle: }\end{array}$ & $\begin{array}{l}\text {-Fully enriched } \mathrm{U} \text { feed }\left(\mathrm{UC}_{2}\right) \\
\text { with thorium }\left(\mathrm{ThO}_{2}\right) \text { fertile } \\
\text { material } \\
\text { - Triso coated fissile particles } \\
\text { - Biso coated fertile particles }\end{array}$ \\
\hline Average fuel residence time & 3 gears & 3.8 years & 4 years \\
\hline Power density of core & 3.4 watts $/ \mathrm{cm}^{3}$ & 5 watts $/ \mathrm{cm}^{3}$ & 10 watts $/ \mathrm{cm}^{3}$ \\
\hline Reactor core $\Delta P$ & 16 psi & 6 psi & $j \mathrm{psi}$ \\
\hline System pressure & $725 \mathrm{psi}$ & 600 psi & $1000 \mathrm{psi}$ \\
\hline Core inlet temperature & $770^{\circ} \mathrm{F}$ & $432^{\circ} \mathrm{F}$ & $807^{\circ} \mathrm{F}$ \\
\hline Reference maximun process temperature & $1.1000^{\circ} \mathrm{F}$ & $1500^{\circ} \mathrm{F}$ & $1600^{\circ} \mathrm{F}$ \\
\hline Core outlet temperature & $1 \equiv 00^{\circ} \mathrm{F}$ & $1742^{\circ} \mathrm{F}$ & $1850^{\circ} \mathrm{F}$ \\
\hline Maximum fuel temferature & $2475^{\circ} \mathrm{F}$ & $2030^{\circ} \mathrm{F}$ & $2158^{\circ} \mathrm{F}$ \\
\hline Type process & Steam-hydrocarbon reformer & Steam-hydrocarbon reformer & Thermochemical water splitting \\
\hline
\end{tabular}


IV. GENERAL CAPABILITIES AND LIMITATIONS OF VHTRS

IN THE PROCESS TEMPERATURE RANGE 1400 TO $2000^{\circ} \mathrm{F}$

\section{A. Core and Fuels}

The unique capabilities of the VHTR are built around the exceptional high-temperature strength of graphite and the ability to encapsulate nuclear fuels in nearly impermeable graphite coatings. All the design concepts benefit from these advantages.

Two types of coated fuel kernels are in common use, BISO and TRISO. BISO and TRISO are acronyms denoting a type of coating. BISO contains two types of coating layers: a low density pyrolytic carbon buffer and high density isotropic pyrolytic carbon to retain the fission products. TRISO contains four coating layers: low density pyrolytic carbon, high density isotropic pyrolytic carbon, silicon carbide and a second layer of high-density pyrolytic carbon. The TRISO kernels maintain their dimensions better during irradiation and contain their fission products more completely than do the BISO type; they are therefore generally preferred for these very high temperatures. The Si introduces a slight amount of neutron poison, increasing fuel costs a minor extent.

Maximum fuel temperatures for various process temperatures are given in Table 4, as presented by the vendors. It is our understanding that Los Alamos Scientific Laboratory will soon publish a verification of the reference GA temperature calculation.

Table 4

Maximum Fuel Temperature, ${ }^{\circ} \mathrm{F}$

\begin{tabular}{ccccc}
\hline Process Temp., ${ }^{\circ} \mathrm{F}$ & 1400 & 1600 & 1800 & 2000 \\
GA & 2475 & $256 \underline{2}$ & 2792 & 3010 \\
GE & 1930 & 2130 & 2330 & 2530 \\
W & 1958 & 2158 & 2358 & 2558 \\
\hline
\end{tabular}

Maximum fuel temperature in the commercial HTGR design is $2560^{\circ} \mathrm{F}$. One might infer from Table 4 that present fuel technology would be adequate for $1600^{\circ} \mathrm{F}$ process temperature for all designs and for 1800 and $2000^{\circ} \mathrm{F}$ for the $\mathrm{GE}$ and $\underline{\mathrm{W}}$ designs. However, average fuel temperature is generally higher in the VHTR designs than in the commercial HTGR. 
Therefore, improved fuels (such as $\mathrm{ZrC}$ coated kernels) are desirable at higher temperatures, especially for the GA design.

The core designex has considerable flexibility in choosing temperature differences between fuel and coolant, in other words, in controlling maximum fuel temperature. Some of the design choices which are open to reduce fuel temperature are the following:

1. Power density. Has disadvantage of increasing core size (capital cost) with decreasing power density.

2. Coolant velocity. Has disadvantage of increasing $\Lambda \mathrm{P}$ with increasing velucity.

3. Reducing heat-flow distance in graphite moderator. Usually reduces strength of the structure and/or increases fabrication costs. For example, more fuel and coolant passages are fabricated, on closer spacing.

4. Control of stagnant gaps between fuel and muderator. For example, TRISO particles maintain narrow gaps better than BISO particles. The Nerva-type fuel eliminates these gaps altogether by having the coolant passages within the extruded fuel element.

5. Fuel management strategy. During refueling it is possible to rearrange fuel elements so that the most reactive (new) fuel is cooled most efficiently. The PBR core couples a two-zone core fueling system to the once-through-then-out (OTTO) fuel cycle to minimize fuel element temperatures. with the OTTO fuel cycle, the fuel makes a single downward pass through the core (parallel to the coolant flow), and the decreasing power output in the lower half of the core coupled to the increasing gas temperature gives a fuel temperature which is very nearly flat through the latter one-half to three-fourths of its life.

\section{B. Reactor Components}

\section{Reactor Vessels}

The GA and GE concepts use large conventional prestressed concrete reactor vessels which are typical of those currently in use for gas 
cooled reactors. These units are within current technology but require completion of present R\&D, particularly on penetrations and head closures, and a scale model test to prove the final design.

The $\underline{W}$ concept specified a prestressed cast iron vessel (PCIV). The recommended design is that of gray cast iron sections (of 60-65 tons each) mechanically assembled around a welded steel liner. The vessel is prestressed circumferentially and axially in the same manner as the prestressed concrete reactor vessel (PCRV) with which the PCIV is compared in this study. The primary advantages sited for choosing cast iron over concrete are that cast iron has a compressive strength 20 times that of concrete while its density and Young's Modulus are three times that of concrete. It is also stated that the use of cast iron will result in a superior structure with reduced weight and size and reduced sensitivity to overtemperature incidents. The design is based on the work of a German firm, siempelkamp. 12

It is felt that the PCIV concept offers some potential advantages and merits further study, but would require considerable R\&D.

\section{Ducting and Insulation}

An insulation system is required to protect the pressure vessel from the hot coolant gas and to minimize the heat losses from the primary coolant and thus the heat load on the pressure vessel cooling system. There are two basic approaches to the problem. The first is to use a high temperature insulation attached to the inside of the ducts and cavities which is exposed to the maximum coolant temperatures. The second method, which reduces the insulation requirements, is to use concentric ducting with the hot helium in the inner duct and the cooler return helium in the outer annulus.

Attaching the insulation to the inner surface of the reactor vessel liner is the method currently used with gas-cooled reactors in the U.S. The ducting insulation consists of a blanket of alumina-silica or a combination of alumina-silica and pure silica fibers held to the liner by metal cover plates and is limited to a continuous average operating temperature of $1500^{\circ} \mathrm{F}$ and local hot spots or streaks of about $1700^{\circ} \mathrm{F}$. Additional insulation in the form of silica blocks capable of withstanding 
higher localized temperature is used on the bottom of the reactor cavity below the core. Thus, the currently used insulation materials and techniques are limited to a reactor outlet temperature of about $1500^{\circ} \mathrm{F}$ or a process temperature of about $1300^{\circ} \mathrm{F}$.

In addition to the temperature and thermal conductivity requirements, the insulation must be capable of withstanding a system depressurization accident without damage to the insulation that would interfere with the auxiliary cooling system; i.e., the insulation must not be displaced in such a manner as to block flow passages essential to the removal of the decay heat following all postiulated accldents.

The problem associated with the insulation of the ducting and cavities is primarily one of developing an adequate mechanical design using currently available insulating materials. The development program will require tests to prove the adequacy of the design in regard to heat losses in a flowing system, noise and vibration effects, and system depressurization accidents.

\section{Heat Exchangers}

The high temperature intermediate heat exchangers are the major items affecting the near-term feasibility of the VHTR and will be the key item in the development of the concept. For process temperatures in the range of 1400 to $1600^{\circ} \mathrm{F}$, the temperature requirements for the IHX are in the range of 1600 to $1850^{\circ} \mathrm{F}$; which is borderline for the available superalloys. Although there are a number of candidate materials for this temperature range, a major development program will be sequired to prove their compatibility with the primary coolant and to obtain sufficient physical data to qualify the materials to some form of ASME, NRC or other codes or standards. These problems are discussed in section IVC.

The mechanical design problems will depend on the material properties and the operating conditions imposed on the units. The requirements for the GE and GA concept should be similar. However, the $\underline{w}$ system may be subjected to greater pressure differential and transient because of control or safety actions required for the turbomachinery.

The $\underline{W}$ concept also has a lower temperature heat exchanger which serves as the compressor precooler. Under normal operation (for the $1600^{\circ} \mathrm{F}$ process temperature case), the helium conditions to the precooler 
are $1200^{\circ} \mathrm{F}$ and $396 \mathrm{psia}$. This unit could be subjected to severe pressure and temperature transients from control or safety requirements.

The steam generator for the GA and GE systems uses operating conditions no more severe than units for commercial HTGR steam plants.

\section{Valves}

The current U.S. gas-cooled reactors use isolation valves for the containment system and the main steam lines, split butterfly-type valves for the core auxiliary cooling system, and shutoff valves to prevent flow reversal through the primary coolant loops. These valves or adaptations should be adequate for the VHTR. The VHTR would also require isolation valves for an intermediate helium loop. The GE concept for these valves is a rotating ball type of design with a closing time of the order of 15-30 seconds. A combination of Inconel, carbon and graphite are used as materials of construction. Some cooling of the valve body might be required which could be done by a low temperature helium stream; internal insulation would also be used. A development and proof testing program would be required for these valves.

The $\underline{w}$ system using gas turbines will require additional primary systems valves for control and overspeed protection of the turbomachinery. Large, quick opening valves will probably be required to protect the turbine from excess speed in the event of a loss-of-electrical load on the unit. Smaller valves for speed control will probably also be required. The operating requirements for these valves will be more severe than for the intermediate loop isolation valves and will require an extensive development and proof testing program.

\section{Materials}

Maximum operating temperatures of components of proposed VHTR-coal conversion systems may range from 1600 to $2200^{\circ} \mathrm{F}$. For many components that will operate below $1000^{\circ} \mathrm{F}$, well established commercial alloys are suitable for use. For temperatures of 1000 to $1600^{\circ} \mathrm{F}$, much of the technology of conventional gas-cooled reactors that has been and is being developed is applicable to many of the components. Temperatures above $1600^{\circ} \mathrm{F}$ place stringent 
limitations on the selection of materials. Strength properties of $\mathrm{Fe}-$ and Ni-base alloys decrease rapidly above $1500^{\circ} \mathrm{F}$ and reactivity with corrosive environments increases. In addition, some of the components in the VHTR systems are unique -- in particular, the process heat exchanger where a material will simultaneously be exposed to both high temperature helium and process environments. It is the purpose of this section to summarize the situation relative to the evaluation and selection of materials for this application.

\section{Reyuirements}

System Conditions and Materials Properties. The most important factors that must be considered in the selection of materlals fur liis appiloation are temperature, stress, environment, and exposure time. The stress on a particular component will depend upon the design conditions selected. For example, it is assumed that the process fluid in the PHX will operate at a pressure close to the primary coolant He pressure to keep tube stresses and creep low in the high temperature portion of the system. The environments to which materials will be exposed are impure helium, hydrogen, steam, and various hydrocarbons. It is expected that materials should ve able to withstand the above conditions for as long as 300,000 hr.

The critical factors thal must be known and ovaluater before a material can be recommended for use are:

a. Mechanical properties

(1) Environmental effects

(2) Pressure vessel cude sequiremento

b. Compatibility

(1) Impure helium

(2) Prnness gases

(3) Steam/Water

c. Structural stability

d. Fabricability
(1) Formability
(2) Weldability
(3) Availability and cost. 
Mechanical properties, compatibility, and structural stability are interacting properties, i.e., lack of compatibility or structural instability can affect a material's mechanical properties. Although flux levels outside the core are low, the effect of radiation on material properties should be known. For certain applications, properties such as resistance to galling and wear are also important.

Pressure Vessel Code Requirements. The design rules governing the construction of nuclear power plant components such as vessels, storage tanks, piping, pumps, valves, and core support structures are covered under Section III, Division 1 of the ASME Boiler and Pressure vessel Code (ASME BPVC). Additionally, Section III provides materials and inspection requirements for nuclear power plant construction. The code does not, however, "cover deterioration which may occur in service as a result of radiation effects, corrosion, erosion, or instability of the material." It is the responsibility of the designer to properly account for these effects to ensure the functionability, integrity, and safety of the structure.

In terms of design, materials, and allowable stresses, there are four categories which are presently considered. These are:

1. Class 1 (highest quality level) components operating at temperatures to 700 and $800^{\circ} \mathrm{F}$, respectively, for ferritic and austenitic materials (Section III, Division 1);

2. Class 1 components at temperatures above those listed but below $1500^{\circ} \mathrm{F}$ (Code Case 1582, Section III);

3. Class 2 (intcrmediate quality level) and Class 3 (moderate quality level) components at temperatures as in 1 above (Section III, Division 1); and

4. Class 2 and 3 components at temperatures above those in 1 but less than $1500^{\circ} \mathrm{F}$. (Section VIII, Division 1 ).

By the classes above, the ASME Code recognizes the different levels of importance associated with the function of each component of the nuclear power plant and allows a choice of rules to assure integrity and quality commensurate with importance. If materials are to be qualified for use above $1500^{\circ} \mathrm{F}$, additional categories will have to be established.

Class 1 components, constructed in accordance with the rules of subsection NB of Section III, must -- In addition to satisfying stress limits 
and design rules under NB-3112 -- be evaluated for additional conditions as follows :

1. Normal conditions;

2. Upset conditions (incidents of moderate frequency);

3. Emergency conditions (infrequent incidents);

4. Faulted conditions (limiting faults); and

5. Testing conditions.

Class 2 (Subsection NC) and Class 3 (Subsection ND) components are evaluated by criteria which du nut explicitly recognize the spesific loading oonditions given above. (See $\mathrm{NC}-3112$ and ND-3112 of section III for specific component design rules.)

Selection of allowable stress values for materials used in the construction of class 2 and 3 components is guided, insofar as possible, by in-service experience. The mechanical properties considered and safety factors applied to provide maximum allowable stresses for design at temperatures below the creep range (i.e., $700^{\circ} \mathrm{F}$ for ferrilic alloy and $800^{\circ} \mathrm{F}$ for austenitic alloys) are:

1. 1/4 of the specified minimum tensile strength at room temperature;

2. $1 / 4$ of tensile strength at service temperature;

3. 5/8 of the specified minimum yield strength at roum temperaturc,

4. 5/8 of the yield strength at service temperature (ferritic alloys only); and

5. $90 \%$ of the yield strength at service temperature but not to exceed $5 / 8$ of the specified minimim yleld strengli at room tomperature (austenitic alloys only).

The maximum allowable stress is always the lowest of Lliuse given above. When Class 2 or 3 components are to operate in the creep range, the maximum allowable stresses are given by the lowest of:

1. $100 \%$ of the average stress for a second stage (minimum) creep rate which, when multiplied by the design lifetime, yields a strain value of $1 \%$;

2. 678 of the average stress for a rupture life equal to the design lifetime; and

3. $80 \%$ of the minimum stress for a rupture life equal to the design lifetime.

When cyclic loading is anticipated, fatigue properties must also be taken into account in design. 
Design stress intensity values for Class 1 components at temperatubes below the creep range are the lowest of the following:

1. $1 / 3$ of the specified minimum tensile strength at room temperature;

2. $1 / 3$ of the tensile strength at temperature;

3. $2 / 3$ of the specified minimum yield strength at room temperature;

4. $2 / 3$ of the yield strength at temperature (ferritic alloys only); and

5. 908 of the yield strength at temperature, but not to exceed $2 / 3$ of the specified minimum yield strength at room temperature (austenitics only).

The design stress intensities for fatigue are obtained from the best fit curve of experimental data -- adjusted where necessary to include the effect of mean stress or a factor of twenty on cycles, whichever is more conservative at each point.

Code Case 1592 to Section III, Division 1 provides stress limits and revised design rules for the use of materials for class 1 components at temperatures in the creep range. (Only four alloys -- 304 and 316 stainless steels, 2 1/4 Cr-1 Mo steel, and Incoloy $800 \mathrm{H} \mathrm{--}$ are currently approved in Case 1592.) The following structural failure modes have been considered in determining stress limits and design rules:

1. tensile instability;

2. gross dictortion by yieldiny;

3. elastic, plastic, and creep buckling;

4. creep rupture;

5. fatigue;

6. creep fatigue;

7. gross distortion by creep; and

8. gross distortion by plastlc and/or creep racheting.

The failure modes above and the design rules resulting from their consideration lead to the following requirements for materials properties information.

1. Minimum yield strength at room temperature.

2. Yield strength versus temperature. 
3. Minimum ultimate tensile strength at room temperature.

4. Ultimate tensile strength versus temperature.

5. Minimum creep-rupture strength versus temperature.

6. Isochronous stress-strain curves versus temperature.

7. A design fatigue curve based on rapid continuous cycling.

8. A design fatugue curve which includes derating for stress relaxation and slow cycling rates.

9. Mean and instantaneous coefficients of thermal expansion.

10. Modulus of elasticity versus temperature.

Time-independent, $s_{m}$, and time-dependent, $s_{t}$, primary stress 1 imits for materials in Code Case 1592 are determined as described below. $S_{m}$, the time-independent value, is the lowest of:

1. 1/3 minimum ultimate tensile strength at room temperature;

2. 0.367 times minimum ultimate tensile strength at elevated temperature;

3. $2 / 3$ minimum yield strength at room temperature;

4. $2 / 3$ minimum yield strength at elevated temperature (ferritic); and

5. 0.90 minimum yield strength at elevated temperature (austenitic).

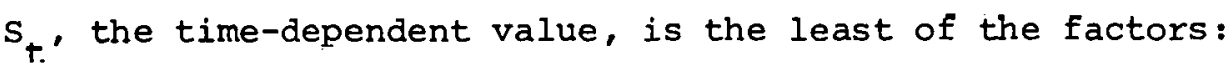

1. 2/3 minimum stress-to-rupture at elevated temperature;

2. $80 \%$ minimum stress to cause tertiary creep at elevated temperature, and

3. $100 z$ minimum stress to a strain of 18 at elevated temperature for a given time, $t$ (the design lifetime).

Finally, the controlling primary stress limit for a given lifetllle d a given temperature is $s_{m t}$ ' the lower of $s_{m}$ and $s_{t}$ under these conditions. Appendix IV to section III, Division 1 describes the prooedure for obtaining ASME Code approval for materials. Some excerpts from this appendix are given below:

.... the inquirer shall furnish the Committee with adequate data on which to base allowable stress value.... (and these) shall include values of ultimate strength, yield strength, reduction in area, elongation, strain fatigue, creep strength, 
and stress rupture strength of base metal and welded joints over the range of temperatures at which the materials is to be used.....

The inquirer shall furnish complete data on the weldability of material intended for welding.....

It is important to know the structural stability characteristics and the degree of retention of properties with exposure at temperature or neutron irradiation....."

It is not difficult, based on the foregoing discussion, to deduce that the code approval or qualification of a material is a complicated, costly, and time-consuming process -- especially for class 1 applications at elevated (creep range) temperatures. Some current estimates of data acquisition and associated costs for Code approval of a "commercial" material under Code Case 1592 run as high as $\$ 3,000,000$ over a period of several years. Qualification of "new" materials would certainly involve considerably higher costs and longer times.

Compatibility Requirements. Materials in a VHTR-coal conversion system will be exposed to one or more of at least three different corrosive environments: helium, water/steam and process reactants and products. The effect of temperature on a given corrosion process can normally be expressed in terms of the Arrhenius equation:

$$
k=A e^{-Q / R T}
$$

where $k$ is the reaction rate, $Q$ is the activation energy required, $A$ is a constant for the particular reaction (but does depend upon the activity of the reactants) and $T$ is the temperature. Thus, if the supply of reactants is not limited and the process is not altered, such as by the formation of adlieient surface films, reaction rate should vary exponentially with temperature.

Oxidation resistant alloys such as stainless steels and $\mathrm{Ni}-\mathrm{Cr}$ alloys generally form protective oxide coatings in air that serve as barriers to further reaction. In situations where the oxidizing potential is low and the temperature is sufficiently high, the oxide film may not be protentive, either because of limited surface coverage, instability of the coating or 
diffusion rates through the film are high. Such situations could result in local and/or intermittent accelerations in reaction rate or breakaway. These conditions can also be conducive to internal oxidation.

Refractory metals do not generally form protective oxide films. At low partial pressures of oxidizing gases, they will internally oxidize until they are saturated. At higher pressures or after longer times, oxide scales form, but they are not generally protective, as they tend to spall or volatilize. Most refractory metals tend to form carbides when exposed to carburizing environments at high temperatures. Carbon pickup can occur with or without the formation of surface films, depending upon the alloy system, piressure of the carburizing specie and temperature. Unlike oxide filins, carbide layers on refractory metals can be protective under certain environmental conditions.

The mechanical behavior of structural materials can be affected by reactions with these environments. However, it is not possible to predict the effects on materials in general, because both strengthening and weakening have been reported after exposure to various environments. Also, it has been observed that the elevated creep strength of some alloys is less when contamination occurs during tests as compared with alloys that are doped with identical impurity levels prior to creep testing. ${ }^{13}$ Alloys exhibiting this characteristic can undergo accelerated creep rates for short periods. In general, these alloys do not form a surface film and this phenomenon is thought to be related to dissolution of the impurity and subsequent precipitation as a grain boundary phase. Gas-metal reactions resulting in the formation of a continuous surface film usually strengthen the material provided the film remains intact.

The VHTR primary coolant is helium and it will contain reactive impurities such as $\mathrm{H}_{2}, \mathrm{O}_{2}$ (very low), $\mathrm{N}_{2}, \mathrm{CO}_{x}$, and $\mathrm{CH}_{x}$. This kind of environithent can be oxidizing or reducing and carburizing or decarburizing with respect to components in an alloy. To determine what materials are compatible with an environment, it is necessary to evaluate the effects of a range of contaminants on each material and then define at what level the alloy becomes unsuitable for a particular application.

Several investigators have attempted to determine the effect of environment on the mechanical properties of materials that are of interest here. 
McCoy ${ }^{14}$ measured the creep-rupture behavior of type 304 stainless steel in $\mathrm{CO}, \mathrm{CO}_{2}, \mathrm{~N}_{2}$, air, argon, $\mathrm{H}_{2}$, and $\mathrm{O}_{2}$ at $1500^{\circ} \mathrm{F}$ and $1700^{\circ} \mathrm{F}$ and found that strain rate increased in the order listed for these environments. Exposure to $\mathrm{CO}-\mathrm{CO}_{2}$ environments resulted in carburization of type 304 stainless steel and increased its creep strength. Wood, Farrow, and Burke ${ }^{15}$ studied the effect of air and helium (two impurity levels: $\mathrm{H}_{2}, \mathrm{CO}, \mathrm{H}_{2} \mathrm{O}$, and $\mathrm{N}_{2}$ on the creep and rupture behavior of 316 stainless steel at $1470^{\circ} \mathrm{F}$ ). Rupture times were shorter and creep rates higher in helium when compared with air. Specimens tested in aix showed thick, relatively uniform scales, while those tested in helium showed non-uniform oxide layers, and selective grain boundary penetration. Other investigators, ${ }^{16,17}$ however, have indicated little differences between air and helium environments on the mechanical properties of stainless steels.

Corrosion rates have also been reported ${ }^{18}$ for Incoloy 800 , Inconel 600, Inconel 617, Hastelloy $\mathrm{x}$, Hastelloy $\mathrm{S}$, and 304 stainless steel after exposure to helium containing impurities at partial pressures similar to those expected to occur in the primary coolant of an operating HTGR. Test conditions were 1200,1400 , and $1600^{\circ} \mathrm{F}$ for times up to $10,000 \mathrm{hr}$. Under these conditions the materials were oxidized to depths of less than 0.002 in. Rate of attack increased with temperature, but the increase from 1400 to $1600^{\circ} \mathrm{F}$ was always less than a factor of two. There was no evidence of carburization nor decarburization of these alloys.

McCoy and Douglas ${ }^{19}$ creep tested niobium at $1700^{\circ} \mathrm{F}$ and $1850^{\circ} \mathrm{F}$ in atmospheres of $\mathrm{Ar}$, Ar plus air, wet $\mathrm{Ar} \mathrm{H}_{2}$, and $\mathrm{N}_{2}$. They found that $\mathrm{O}_{2}$ increased the creep strength but testing in $\mathrm{H}_{2}$ and $\mathrm{H}_{2} \mathrm{O}$ greatly reduced the creep strength. The creep ductilities of the specimen were not appreciably impaired even after a pickup of $5100 \mathrm{ppm} \mathrm{O}_{2}$. Nitrogen, however, was found to have a significant strengthening effect. $\mathrm{A} \mathrm{N}_{2}$ concentration of $1000 \mathrm{ppm}$ seriously embrittled $\mathrm{Nb}$ and $2000 \mathrm{ppm}$ doubled its room temperature proportional limit but reduced its ductility to essentially zero. At $1800^{\circ} \mathrm{F}$ strains at rupture were 9-188 after the addition of 2000-3000 ppm $\mathrm{N}_{2}$ to $\mathrm{Nb}$. Contrarily, stoop and Shahinian ${ }^{20}$ found no influence of nitrogen up to 4600 ppm on the ductility of niobium at $1900^{\circ} \mathrm{F}$. 
Liu and Inouye ${ }^{21}$ determined the tensile properties of TZM (Mo-0.5\% $\mathrm{Ti}-0.08 \% \mathrm{Zr}-0.038 \mathrm{C}$ ) after exposure to low pressure $\mathrm{O}_{2}, \mathrm{CO}$, and $\mathrm{H}_{2} \mathrm{O}$ at $1520^{\circ} \mathrm{F}$ and $1832^{\circ} \mathrm{F}$. Specimens exposed to $\mathrm{O}_{2}$ at $1 \times 10^{-5}$ torr for $2000 \mathrm{hr}$ at $1520^{\circ} \mathrm{F}$ showed small increases in strength and decreases in ductility in room temperature tensile tests. However, room temperature ductility decreased rapidly when the exposure temperature was raised to $1832^{\circ} \mathrm{F}$, and complete embrittlement occurred when the samples contained $300 \mathrm{ppm} \mathrm{O}_{2}$. This embrittlement was felt to be the result of internal oxidation of $\mathrm{Ti}$ and 7.r. in the a.1 1 ny.

Based on reactivity with oxygen, it might be expected that molybdenum would be less susceptible to high temperature gaseous corrosion than $\mathrm{Nb}$ or Ta. After $500 \mathrm{hr}$ at $2100^{\circ} \mathrm{F}$ in $300 \mathrm{psi}$ helium containing less than $1 \mathrm{ppm}$ (principally $\mathrm{H}_{2}$, no oxygen detected), $\mathrm{Nb}$ and $\mathrm{Ta}$ were significantly contaminated by oxygen and carbon while Mo and $\mathrm{W}$ were unaffected. ${ }^{22}$ At temperatures below $1400^{\circ} \mathrm{F}_{2} \mathrm{H}_{2}$ can significantly embrittle $\mathrm{Nb}$ and $\mathrm{Ta}$. Molybdenum and $w$, however, do not appreciably interact with $\mathrm{H}_{2}$. Chandler and walter 23 have published a comprehensive review of the effects of hydrogen on refractorg metalc.

Oxide ceramics generally have good resistance to strongly oxidizing environments such as air. S1llca, however, cansul be used under reducing conditions at high temperatures because it forms a volatile lower oxide, sio. Beo readily volatilizes when exposed to water vapor above $3000^{\circ} \mathrm{F}$ and, when heated in the atmospheres of gas-fired furnaces, loses a considerable amount of weight. ${ }^{24,25}$ Alumina is chemically one of the most stable and mechanically one of the strongest refractory oxides at moderate temperatures. It is resistant to all gases except $\mathrm{F}_{2}$ at temperatures in excess of $3000^{\circ} \mathrm{F},{ }^{26}$ and is stable in both oxidizing and reducing atmospheres.

Silicon carbide is stable in air below $1800^{\circ} \mathrm{F}$ and above $2150^{\circ} \mathrm{F}$ but oxidizes rapidly between these temperatures. ${ }^{27}$ silicon nitride, $\mathrm{Si}_{3} \mathrm{~N}_{4}$, is very stable in air, but tends to corrode rapidly in lightly oxidizing environments due to the formation of volatile sio.

The conditions expected in the PHX of a VHTR-coal conversion system severely restricts the choice of construction materials. Corrosion reactions involving impure helium have already been discussed. Process atmospheres will contain $\mathrm{H}_{2} \mathrm{O}, \mathrm{H}_{2}, \mathrm{CO}, \mathrm{CO}_{2}, \mathrm{~N}_{2}, \mathrm{H}_{2} \mathrm{~S}$, numerous hydrocarbons, and 
other types of corrodants such as chloride salts. Hydrogen embrittlement, carburization, sulfidation, stress corrosion and pitting are some of the corrosion processes that can occur. In addition, the presence of solid particles in the gaseous stream can lead to deterioration by erosion. Programs are currently underway to assess the compatibility of materials with process environments, but data are sparse thus far. Experiments are also underway to investigate the possibility of coating a conventional material substrate with a corrosion resistant material. Metallic, ceramic, cermet and mixed oxide-cermet coatings are being investigated. Oxide ceramic coatings appear stable with respect to oxidizing environments, but there are some data to suggest that $\mathrm{s}^{--}$rapidly penetrates these coatings and attacks the substrates. Nickel-base metallic coatings appear to resist oxidation better than cobalt-base coatings, but the latter are more resistant to attack from sulfidation.

Water/steam compatibility with materials being considered for HTGR steam generators has recently been reported. ${ }^{28}$ For applications above $800^{\circ} \mathrm{F}$, Incoloy 800 and $21 / 4 \mathrm{Cr}-1$ Mo steel are being considered. Data on steam corrosion of $21 / 4 \mathrm{Cr}-1$ Mo steel was previously reviewed by Chakraborty ${ }^{29}$ in 1972. For construction of a $950^{\circ} \mathrm{F}$ steam generator for the LMFBR, corrosion allowance of 0.010 to 0.027 in. have been recommended to account for general corrosion and periodic descaling. The current HTGR design includes a $0.030 \mathrm{in}$. allowance for a 40-year design life. A number of investigators ${ }^{30-33}$ have studied the corrosion behavior of Incoloy 800 from $1050^{\circ} \mathrm{F}$ to $1380^{\circ} \mathrm{F}$ in superheated steam with a variety of oxygen and other contaminants. The highest rate reported was $0.001 \mathrm{in./yr}$ for a three year test at $1300^{\circ} \mathrm{F}$ in steam containing $20 \mathrm{ppm} \mathrm{O}_{2}, 2-3 \mathrm{ppm} \mathrm{H}_{2}$ and 0.5 ppm chloride. Some data have been reported ${ }^{34}$ which suggest that general corrosion rates may increase under heat flux conditions. Recent work in Germany ${ }^{35}$ showed no such effect in tests at $840^{\circ} \mathrm{F}$ to $1300^{\circ} \mathrm{F}$ and 2200 psig. Tests are currently being carried out at $\mathrm{ORNL}^{36}$ to evaluate the effect of heat flux on the general corrosion rate of $21 / 4 \mathrm{Cr}-1$ Mo steel.

The alloy 2 1/4 $\mathrm{Cr}-1$ Mo has been found to resist stress corrosion cracking in steam environments ${ }^{37}$ containing up to $10 \mathrm{ppm} \mathrm{Cl}^{-}$. Stresscorrosion susceptibility of austenitic alloys has received extensive study at General Atomic. 38 Tests performed on alloys such as Incoloy 800 have 
ranged from accelerated conditions (boiling magnesium chloride, oxygen/ chloride contaminated steam, etc.) to exposure under more realistic conditions. Specimens that were fully sensitized, unsensitived, with residual stresses from a bend, and with stresses near yield from a clamped bend, were tested. Incoloy 800 proved to be extremely resistant to stress corrosion in these tests.

In one series of autoclave tests, tube-to-tubesheet joint mockups were exposed intermittently to wet steam at $316^{\circ} \mathrm{C}$ containing $2 \mathrm{ppm}$ chloride and several ppm oxygen. To increase the severity of some tests, the steam was saturated with air. In all of these tests, Tncoloy 800 tubes survived with $n o$ evidence of stress corrosion cracking while type 304 stainless steel tubes suffered stress corrosion cracking when exposed to the oxygen-hearing environment.

In another series of autoclave tests, bend specimens of Incoloy 800 and Incoloy 800-to-2 $1 / 4 \mathrm{Cr}-1$ Mo steel bimetallic welds were exposed at $316^{\circ} \mathrm{C}$ to wet steam containing $2 \mathrm{ppm}$ chloride and $5 \mathrm{ppm}$ oxygen. After 1000-hr neither specimen showed evidence of stress corrosion cracking. Structural Stability of Materials. Alloys heated to high temperature often undergo microstructural changes which generaily aftect their properties. This is a very serious concern for long time high temperature components, since it can result in a loss of mechanical strength and ductility during operation. Instabilities can take the form of:

1. Recrystallization

2. Grain Growth

3. Phase Changes
a. Dissolution
b. Precipitation
C. Now Phaseg

4. Phase Agglomeration

Ferritic alloys undergo grain growth above $1650^{\circ} \mathrm{F}$ which lowers their impact strength at room temperature. Steels containing Mo are particularly susceptible to recrystallization and grain growth above $1400^{\circ} \mathrm{F}$. Unalloyed molybdenum has been observed to recrystallize as low as $1650^{\circ} \mathrm{F}$ depending upon prior history. Molybdenum is a particularly structure sensitive material which has its best properties in the fine-grained condition. 
Chromium steels containing less than $13 \% \mathrm{Cr}$ are subject to temper embrittlement when heated to $750-1000^{\circ} \mathrm{F}$, but properties can be restored by heating to more than $1100^{\circ} \mathrm{F}$. Nickel-base alloys, particularly those that are $\gamma^{\prime}$ strengthened, are prone to $\gamma^{\prime}$ agglomeration which reduces their creep strength and ductility. ${ }^{39}$ The formation of sigma phase (FeCr) in high chromium steels at $1020-1470^{\circ} \mathrm{F}$ greatly löwers impact strength of these alloys.

Liu, et al. ${ }^{13}$ found that Ta-8\% $\mathrm{W}-2 \%$ Hf could tolerate oxygen levels as high as $4200 \mathrm{ppm}$ before completely losing its ductility if the alloy was annealed at $3100^{\circ} \mathrm{F}$ after being doped at $1832^{\circ} \mathrm{F}$. However, without the annealing treatment the specimens were completely embrittled at 800 ppm oxygen.

Many Fe- and Ni-base alloys depend upon carbide precipitates for their high temperature strength and corrosion resistance. When these alloys are heated to high temperatures, the carbides may agglomerate or change morphology. These changes can result in losses in strength and/or ductility of the alloy.

Some oxide ceramics such as hafnia, zirconia, and silica undergo phase transformations that limit their use. Ceramics such as alumina, beryllia, silicon carbide and silicon nitride are structurally stable at the temperatures of interest to VHTRs.

Fabrication. The fabricability of potential materials for this application varies widely. In general, alloys with increasing strength are more difficult to fabricate. Superalloys stich as Rene'-80, U-700, and IN-738 are neither fabricable nor weldable. High strength alloys such as waspalloy and U-500 are fabricable into primary shapes, but would be difficult to make into thin-walled tubing and are crack sensitive when welded. Molybdenum can be fabricated into the required shapes, but is crack sensitive when welded. Molybdenum welds have ductile-brittle transition temperatures of $500^{\circ} \mathrm{F}$ or higher.

Many of the stainless steels, Inconels, Hastelloys, and Incoloys are readily fabricable and weldable. Techniques are well established, and there has been considerable industrial experience with these materials. Niobium and tantalum metal and alloys are also readily fabricable and weldable. 
However, an inert protective atmosphere is required during high temperature metal working to prevent embrittling. In addition, tantalum is quite expensive relative to conventional alloys.

Ceramic materials are difficult to fabricate and join and exhibit poor toughness, especially in tension. If used, designs will have to keep these materials under compression. Several techiques are available for fabricating ceramics into shapes. These include: reaction-sintering, hot pressing, chemical vapor deposition, and ion plating. Methods of joining include (1) merhanirai,, (2) brazing, and (3) high Leinierature diffucion bonding: An alternative to constructing the $\mathrm{HHX}$ of a cerallic material is to coat a conventional material substrale with a ceramic. Tochnifues inrlure. (1) plasma spraying, (2) diffusion bonding, (3) ion plating, (4) CVD, and (5) PVD. Most such methods are expensive and considerable development would be required before complicated shapes could be satisfactorily coated.

2. Candidate Materials for Nuclear Power Plant Construction

Temperature classification. This section will describe the classes of materials which are available for the construction of components and structures of nuclear power plants. Whenever possible, emplasis has been placed on those materials which are currently acceptable under Seclion III of the ASME BPVC for use in Class 1, 2, and 3 components. Classification of materials is based primarily on their potential sexvice temperature capabilities.

Component temperatures less than $700^{\circ} \mathrm{F}$. All of the many carbon steels, low-alloy steels, ferritic stalniess sletls, austenitic stainlere stepls, and Ni-base alloys given in Appendix I to Section III, Division 1 of the ASME BPVD are available for use in Class 1-3 components at temperatures to $700^{\circ} \mathrm{F}$. Examples of design stresses for typical materials are given in Tables 5 through 9. At $700^{\circ} \mathrm{F}$ environmental effects in helium and in most process applications should not significantly affect mechanical properties. 
Table 5

Design Stresses for SA-387, Grade 2

$1 / 2 \mathrm{Cr}-1 / 2$ Mo Steel Plate

\begin{tabular}{cccc}
\hline \multirow{2}{*}{$\begin{array}{c}\text { Temperature } \\
{ }^{\circ} \mathrm{F}\end{array}$} & \multicolumn{3}{c}{ Allowable Stresses (ksi) } \\
\cline { 2 - 4 } 100 & Class 1; Sect. III & Class 2, 3; Sect. III & Class 2, 3; Sect. VIII \\
200 & 18.3 & 17.5 & 13.7 \\
300 & 18.3 & 17.5 & 13.7 \\
400 & 18.3 & 17.5 & 13.7 \\
500 & 18.3 & 17.5 & 13.7 \\
600 & 18.3 & 17.5 & 13.7 \\
700 & 18.3 & 17.5 & 13.7 \\
800 & 13.2 & 17.5 & 13.7 \\
900 & & & 13.4 \\
1000 & & & 13.1 \\
1050 & & & 10.0 \\
\hline
\end{tabular}


Tále 6

Design Stresses for SA-213, T-22 $21 / 4 \mathrm{Cr}-1 \mathrm{Mc}$

Steel. Seanless Tubing

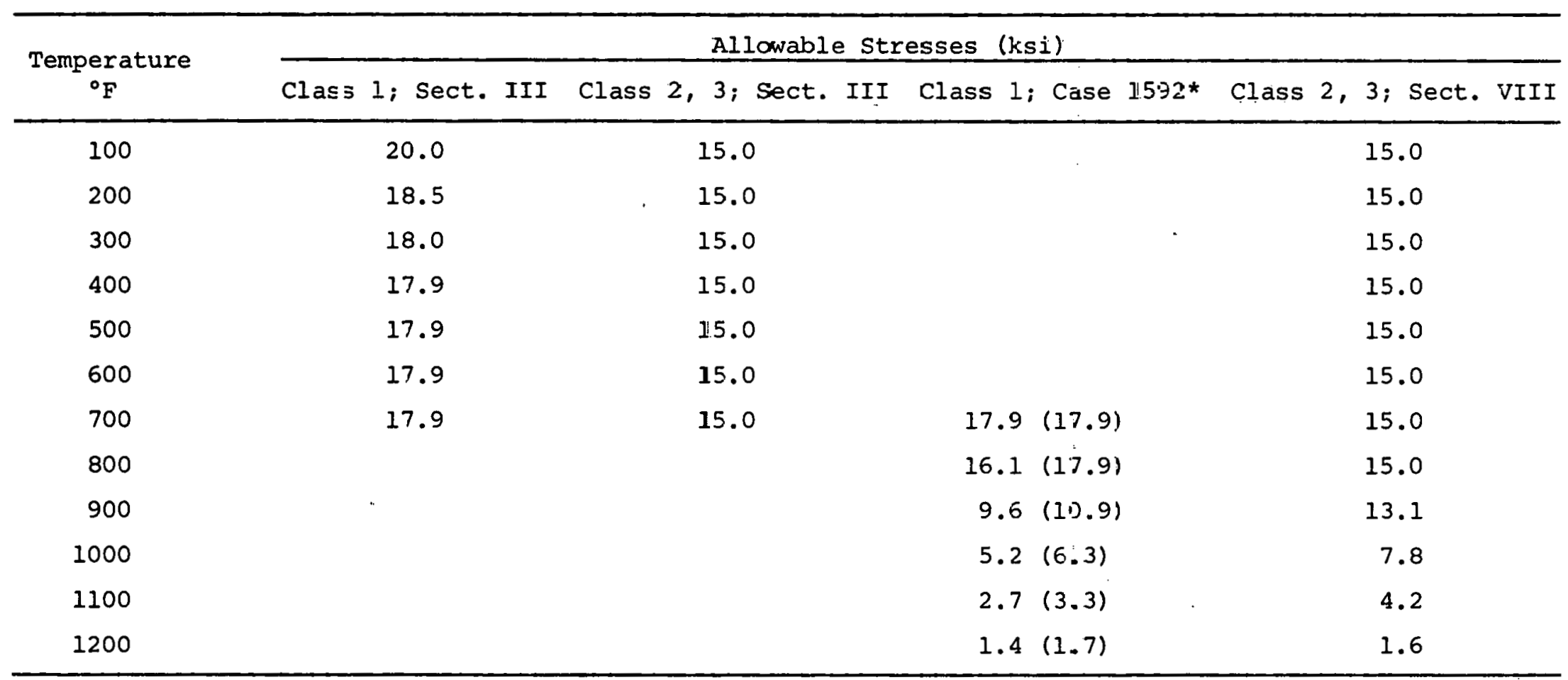

${ }^{*} S_{m t}, t=300,000 \mathrm{hr} ;(t=100,000 \mathrm{hr})$. 
Table 7

Design Stresses for SA-240, Grade 40512 Cr-Al Ferritic Stainless Steel Plate

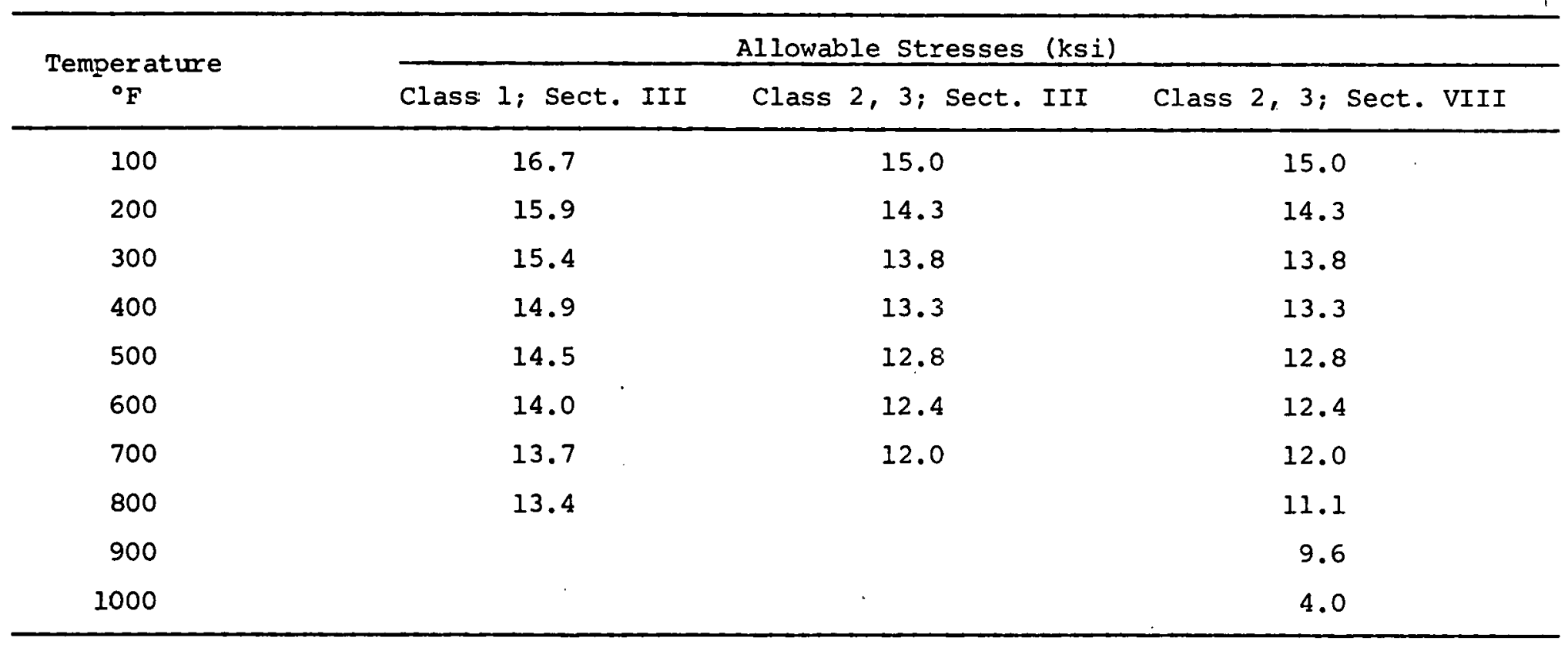


Table 8

Design Stresses for SA-240, Grade $30418 \mathrm{Cr}-\varepsilon \mathrm{Ni}$ Austenitic Stainless Steel Plate

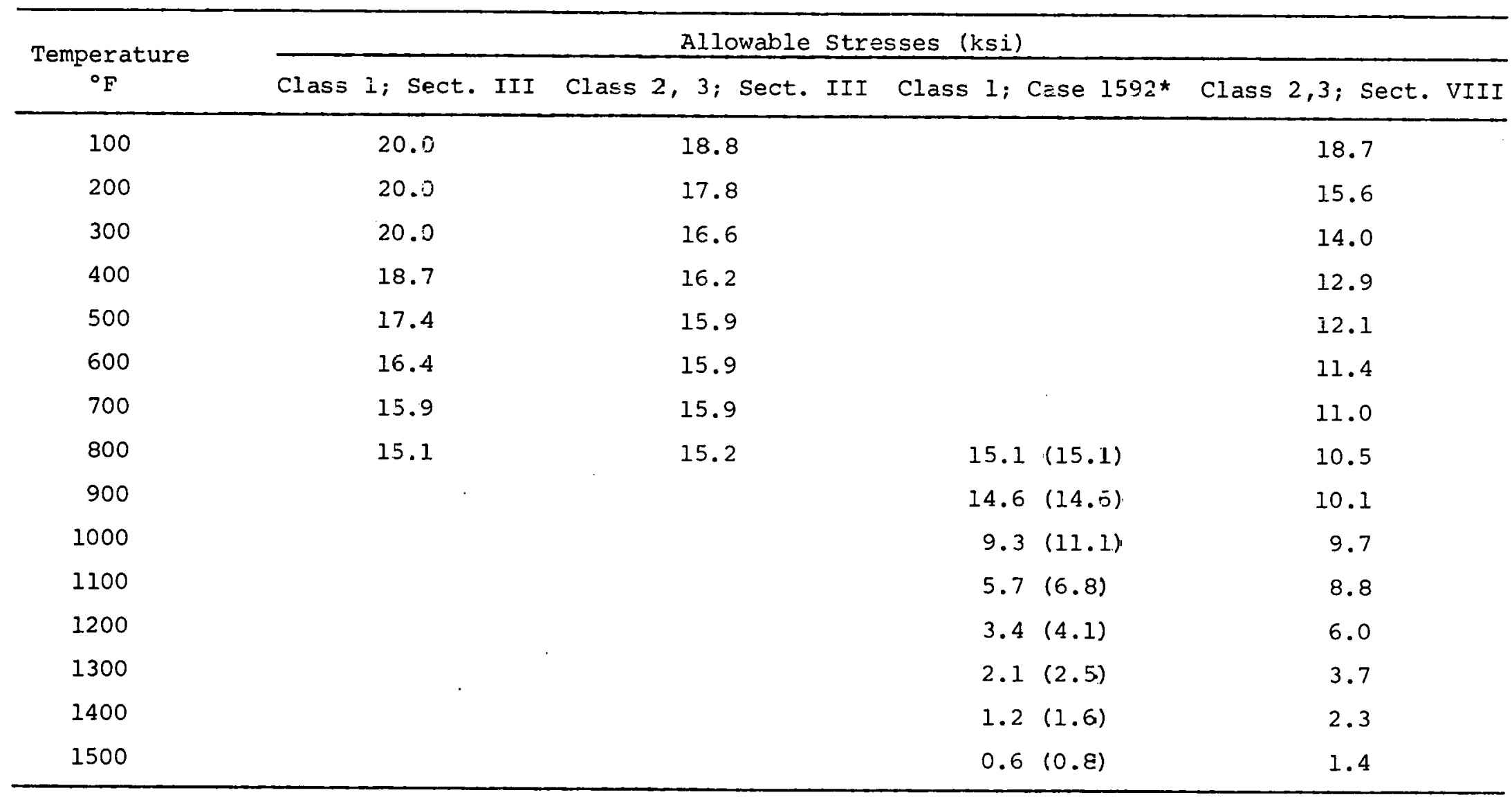

${ }^{*} \mathrm{~S}_{\mathrm{m} t^{\prime}} t=300,000 \mathrm{hr} ;(t=100,000 \mathrm{hr})$. 
Table 9

Desigr. Stresses for SB-163, Ni-Fe-Cr Allcy $800 \mathrm{H}$

Seamless Tubing (Incoloy $800 \mathrm{H}$ )

\begin{tabular}{|c|c|c|c|c|c|c|c|c|c|c|c|c|}
\hline \multirow{2}{*}{$\begin{array}{c}\text { Tenperature } \\
{ }^{\circ} \mathrm{F}\end{array}$} & \multicolumn{12}{|c|}{ Allowable Stresses (ksi) } \\
\hline & Class & $1 ;$ Sect. & III & Class & 2,3 ; sect. & III & Class & $1 ; C$ & Case 1592 * & Class 2 & 2,3 ; sect. & VIII \\
\hline 100 & & 16.7 & & & 15.6 & & & & & & 16.2 & \\
\hline 200 & . & 16.7 & & & 13.4 & & & & & & 14.3 & \\
\hline 300 & & 16.7 & & & 12.1 & & & & & & 12.9 & \\
\hline 400 & & 15.8 & & & 11.1 & & & & & & 11.9 & : \\
\hline 500 & & 14.9 & & & 10.4 & & & & & & 11.0 & \\
\hline 600 & & 14.6 & & & 10.0 & & & & & & 10.6 & \\
\hline 700 & & 14.3 & & & 9.6 & & & & & & 10.2 & \\
\hline 800 & & 14.0 & & & 9.3 & & & $15: 3$ & $3(15.3)$ & & 9.9 & \\
\hline 900 & & & & & & & & 14.8 & $8(14.8)$ & & 9.7 & \\
\hline 1000 & & & & & & & & 14.4 & $4(14.4)$ & & 9.4 & \\
\hline 1100 & & & & , & & & & 10.3 & $3(11.7)$ & & 9.4 & \\
\hline 1200 & & & & & & & & 6.4 & $4 \quad(7.2)$ & & 7.9 & \\
\hline 1300 & & & & & & & & & $1(4.6)$ & & 4.6 & \\
\hline 1400 & & & & & & & & 2.6 & $6(3.0)$ & & 2.8 & \\
\hline 1500 & & & & & & & & & & & 1.7 & \\
\hline
\end{tabular}

${ }^{*} s_{m t}, t=300,000 \mathrm{hr} ;(t=100,000 \mathrm{hr})$. 
Component temperatures of 700 to $1100^{\circ} \mathrm{F}$. For temperatures up to $1100^{\circ} \mathrm{F}$, Class 2 and 3 components can be constructed from most of alloys listed in Appendix I to Section III, Division 1 of the Code. However, there are some exceptions as shown in Tables 5 and 7 . For example, SA-387, Grade $21 / 2 \mathrm{Cr}-$ $1 / 2$ Mo steel plate has a maximum acceptance temperature of $1050^{\circ} \mathrm{F}$, and $\mathrm{SA}-240$, Grade 405 stainless steel plate is limited to use at $1000^{\circ} \mathrm{F}$. Class 1 components operating up to $800^{\circ} \mathrm{F}$ can utilize the many austenitic alloys in Appendix I, but for Class 1 service above $800^{\circ} \mathrm{F}$, only those materials covered in Code Case 1592 (i.e., 2 1/4 Cr-1 Mo, 304 stainless steel, 316 stainless steel, and Incoloy 800H) have been approved. It is important to note that environmental effects may become a consideration for some alloys in this temperature range.

Component temperatures of 1100 to $1500^{\circ} \mathrm{F}$. Components of Class 2 and 3 can utilize some of the austenitic alloys up to $1500^{\circ} \mathrm{F}$ (see Tables 8 and 9); however, only 304 and 316 stainless steel are qualified for use with Class 1 components. Incoloy $800 \mathrm{H}$ and $21 / 4 \mathrm{Cr}-1$ Mo steel can also be used for class 1 components to temperatures of $1400^{\circ} \mathrm{F}$ and $1200^{\circ} \mathrm{F}$, respectively. We cannot, however, endorse the use of this latter alloy (i.e., $21 / 4 \mathrm{Cr}-1$ Mo steel) or other ferritic materials for use in this temperature range because of relatively low strength (see Table 6). Other alloyjs, not currently covered in the ASME Code, are also potential candidates for service in the 1100 to $1500^{\circ} \mathrm{F}$ temperature range. These include stainless steels of the $25 \mathrm{Cr}-20 \mathrm{Ni}$ type (with stress-to-rupture in 100,000 hr at $1500^{\circ} \mathrm{F}$ about 508 greater than for Incoloy $800 \mathrm{H}$ ) and $\mathrm{Ni}$-base alloys such as Hastelloy $\mathrm{X}\left(100,000 \mathrm{-hr}\right.$ rupture stress at $1500^{\circ} \mathrm{F}$ approximately Lwice that for Incoloy $800 \mathrm{H}$ ) and Inconel 617 (with still higher creep resistancc). Environmental effects (primary coolant helium, steam/water, and process gas environments) and thermal stability will have to be concidered carefully for whatever materials are selected.

Component temperatures of 1500 to $1800^{\circ} \mathrm{F}$. There are no materials currently qualified by the ASME Code for use in the construction of nuclear power plant components at temperatures above $1500^{\circ} \mathrm{F}$. A number of $\mathrm{Ni}$ - and Co-base alloys have been developed for use in this temperature range, primarily in jet engines and gas turbine applications. Commercial Co-base alloys, although relatively strong in the 1500 to $1800^{\circ} \mathrm{F}$ range, cannot be 
considered for nuclear application because of radioactive co contamination problems. (Even Ni-base alloys containing substantial Co - including Inconel 617 mentioned earlier - are suspect in this regard.) The Ni-base alloys are, in general, quite strong at $1500^{\circ} \mathrm{F}$ but their strength decreases significantly between 1500 and $1800^{\circ} \mathrm{F}$ (by factors of 3 to 5), and 1000-hr rupture strengths fall to $4000 \mathrm{psi}$ and less. Examples of such alloys are Hastelloy $X$, Inconel 617, and Inconel $x-750$. Alloys which maintain reasonable strengths to $1800^{\circ} \mathrm{F}$ are of the cast, type (e.g., Alloy 713LC and Inconel MA-753). These, of course, have only limited applicability in nuclear component construction because of fabrication and joining difficulties. Development of other Ni-base alloys, both solid solution strengthened and dispersion strengthened with improved fabricability and strength, is of course, possible but by no means a certainty.

Refractory metals and their alloys certainly possess adequate strengths for use in this temperature range, but they are, in general, susceptible to interstitial embrittlement. At present, only alloys based on Mo could be considered as serious candidates for this service and, then, only in connection with the helium coolant. Strengths are excellent with the stress for rupture in $100,000 \mathrm{hr}$ at $1800^{\circ} \mathrm{F}$ exceeding 15,000 psi for Mo-TZM. This is more than a factor of 10 greater than the strengths of most Ni-base alloys.

Ceramics may also be considered for some applications in this temperature range but their use in critical structural support and pressure retaining components is almost certainly outside the current status of technology.

Serious fabrication problems will be encountered with many of the materials mentioned as candidates for use in this temperature range. Little or nothing is known with respect to their long-term thermal stability and/or interactions with the environment. None are ASME Code approved and such approval will be achieved only with costs and efforts greater than those outlined in the section on Pressure Vessel Code Considerations.

Component temperatures above $1800^{\circ} \mathrm{F}$. Conventional Ni-base alloys are almost certainly out of consideration at these temperatures. Mo or Mobase alloys have sufficient. strength for use at temperatures significantly grcater than $2000^{\circ} \mathrm{F}$; however, fabricability and compatibility with process environments are major areas of concern. Ceramics must be more seriously 
considered at these temperatures, and this involves the development of innovative designs and fabrication and joining technology. All of the problems mentioned for 1500 to $1800^{\circ} \mathrm{F}$ materials will likely be magnified.

Assessment of Material Candidates as a Function of Temperature. The principal high temperature components of a VHTR-coal conversion system are the hot ducts, insulation covers, process heat exchangers (PHX), optional intermediate heat exchangers (IHX), steam generators and various valves and seals. Some typical materials that might be used in constructing these components are presented in Tables 10 through 13 . Based on the previous discussions of materials requirements, we have also attempted to evaluate the probability that the materials suggested will be satisfactory in these applications.

Table 10 lists the materials candidates for a system that provides heat for a $1400^{\circ} \mathrm{F}$ process temperature. For this application, several candidate materials are available for all of the components. The major problem areas are the hot ducts and PHX since none of the candidate materials have been Code approved. In addition, materials compatibility with the process environment is unknown in most cases. Nonetheless, considering experience with petrochemical processes, we feel that there is a high probability that suitable materials can be obtained and qualified for components to be used in a $1400^{\circ} \mathrm{F}$ process system.

If the process temperature increases to $1500^{\circ} \mathrm{F}$, the hot duct will operate at $1650-1850^{\circ} \mathrm{F}$ depending on the design. PHX and IHX components will also operate in this same range, and the probability of finding satisfactory materials decreases markedly relative to the $1400^{\circ} \mathrm{F}$ process, primarily because important material properties are unknown.

At process temperatures of $1600^{\circ} \mathrm{F}$ and higher, Mo or Mo-base alloys, ceramics, and/or ceramic coated materials will undoubtedly be required for the hot ducts and the IHX, and in some cases for the PHX. Each of these materials pose difficult fabrication and joining problems. In addition, the probability of compatibility problems increases as temperature is increased. Since we can not as yet identify specific candidate materials for these higher temperatures, the chances of constructing such a system cannot be assured. 
Table 10

Material Candidates for Critical Components of the $1400^{\circ} \mathrm{F}$ Process Temperature VHTR

$\begin{array}{cccc}\text { Maximum } & & \text { Probability } \\ \text { Operating } & \text { Uf } & \text { Ultimate } \\ \text { Temp. Range } & \text { Typical Candidate Materials } & \text { Potential Problem Areas } & \text { Applicability }\end{array}$

\section{Without IHX}

Hot Duct
Insulation
Covers

PHX

Generatcr

Valves and Seals

Hot Duct

Insulation

Covers

IHX

PHX

Steam

Generator

Valves and

Seals
$1550-1 € 50$

$1550-1650$

$1050-1250$

$1350-\$ 450$ high-alloy ferritics.

$\mathrm{Ni}$-base alloys and austenitic steels such as Inconel 718 and 347 SS.

\section{With IHX}

1. Same as without IHX.

2. Mo-base alloy.

3. Advanced super alloys.

4. Ceramics.

1650-1750 Same as above.

$1500-1500$

Same as PHX without IHX.

$1050-1253$

$1500-1600$
Same as stear: generator without IHX.

Ni-base alloys, austenitic stainless steels.
Thermal stability. Effects of He

environment. Not ASME code approved.

Co contamination (Inconel 617).

Same as above. Effects cf process environment.

Effects cf He and steam environments. Code approval of high alloy ferritics.

Effects of environment. Thermal stability. Code approval. Wear and galling problems.

1. Same as without IHX, strength

2. Fabrisability, environmental effects, Code approval.

3. All aspects from alloy development through Code approval.

4. Fabricability, shock resistance, environmental effects, Code approval.

As above.

As PHX without IHX.

As steam generator without IHX.

Effects of environment. Thermal stability Code approval of materials. Wear and galling problems.
Good.

Potentially good, but effect of process environment largely unknown.

\section{Excellent.}

Good
1. Fair.

2. Potentially good, but

unknown.

4. Unknown.

As above.

Potentially good but effect of process environment largely unknown.

Excellent

Fair-to-good. 
Table 11

Material Candidates for critical Components of a

$1520^{\circ} \mathrm{F}$ Process Temperature ViTR

\begin{tabular}{|c|c|c|c|c|}
\hline Component & $\begin{array}{c}\text { Maximum } \\
\text { Operating } \\
\text { Temp. Range } \\
\text { (० } \mathrm{F}: \\
\end{array}$ & Typical Candidate Materials & Potential Problem Areas & $\begin{array}{l}\text { Probability } \\
\text { of } \\
\text { Ui-timate } \\
\text { Apficability }\end{array}$ \\
\hline \multicolumn{5}{|c|}{ Wi-r.out IHX } \\
\hline $\begin{array}{l}\text { Hot Duct } \\
\text { Insulation } \\
\text { Covers }\end{array}$ & $1650-1750$ & $\begin{array}{l}\text { 1. Sclid solulion strengthened } \\
\text { Nibase alloys. }\end{array}$ & $\begin{array}{l}\text { 1. Thermal stability, effects of } \\
\text { envirorment, ASME Code approval, } \\
\text { strength. }\end{array}$ & 1. Fair. \\
\hline & & 2. Mo-base alloys. & $\begin{array}{l}\text { 2. Fabricability, environmenta:- } \\
\text { effects, Code approval. }\end{array}$ & $\begin{array}{l}\text { 2. Potentially good but } \\
\text { many unknowns. }\end{array}$ \\
\hline & & $\equiv$ Adi-ance. superalloys. & $\begin{array}{l}\text { 3. A1l aspects from alloy deve opmen: } \\
\text { through Code appreval. }\end{array}$ & 3. Unknown. \\
\hline & & 4. Ceramics. & $\begin{array}{l}\text { 4. Zabricability, shock resistance, } \\
\text { environmental effects, Code } \\
\text { approval. }\end{array}$ & 4. Unknown. \\
\hline PHX & $1650-1750$ & $\begin{array}{l}\text { Same as abore except omit } \\
\text { No-base ail=ys. }\end{array}$ & $\begin{array}{l}\text { Same as above plus effects of process } \\
\text { environment. }\end{array}$ & As above. \\
\hline $\begin{array}{l}\text { Steam } \\
\text { Generator }\end{array}$ & $1125-1325$ & $\begin{array}{l}\text { Alloy } 8.00 \mathrm{H}, 3 \mathrm{C} 4 \text { SS, stabilized } \\
\text { high-a:loy ferritics. }\end{array}$ & $\begin{array}{l}\text { Effec:s of He arid steam environgent. } \\
\text { Code approval of high-alloy ferritics. }\end{array}$ & Goxd-to-excellent. \\
\hline \multirow[t]{2}{*}{ Valves and } & $1450-1550$ & $\begin{array}{l}\text { ui-base alleys, austenitic } \\
\text { stainless steels. }\end{array}$ & $\begin{array}{l}\text { Effects of environment, thermal sta- } \\
\text { tility, Code approval fcr }>1500^{\circ}: \\
\text { applications (Ciass } 2,3 \text { ) and all class L } \\
\text { tses, wear and galling. }\end{array}$ & Go:d. \\
\hline & \multicolumn{3}{|c|}{ With IHX } & \\
\hline $\begin{array}{l}\text { Hot Duct } \\
\text { Insulation } \\
\text { Covers }\end{array}$ & $1750-1850$ & $\begin{array}{l}\text { Same as hot dLct without IHX } \\
\text { except solid so-ution Ni- } \\
\text { alloys. }\end{array}$ & Same as hot duct without IHX. & Sarue as hot Auct without IHX. \\
\hline IHX & $1750-1850$ & Same as atove. & Same as above. & Same as aloove. \\
\hline PHX & $1600-1700$ & Same $三 s$ PHX w-thout IHX. & Same as PHX without IHX. & $\begin{array}{l}\text { Fa-r-to-good but applicability } \\
\text { of ceramics and advanced super- } \\
\text { alioys unknown. }\end{array}$ \\
\hline $\begin{array}{l}\text { Steam } \\
\text { Generator }\end{array}$ & $1125-1325$ & Same as steam generator withoit IHX. & Same as steam generator without: IHX. & Good-to-excellen=. \\
\hline $\begin{array}{l}\text { Valves and } \\
\text { Seals }\end{array}$ & $1600-1.700$ & $\begin{array}{l}\text { 1. Sane as valives and seals with- } \\
\text { out IHX bat more restric:ive. } \\
\text { 2. Cast N--b.ase alloys. }\end{array}$ & $\begin{array}{l}\text { 1. Fffectr of environment, themal } \\
\text { stability, Code aoproval, rear and } \\
\text { galling, strength. } \\
\text { 2. Same as above but perhaps nore } \\
\text { serious stability problems and } \\
\text { fabricability questions. }\end{array}$ & $\begin{array}{l}\text { 1. Fair-to-good. } \\
\text { 2. Fair. }\end{array}$ \\
\hline
\end{tabular}


Table 12

Material Candidates for Critical Components of a $1600^{\circ} \mathrm{F}$ Process Temperature VATR

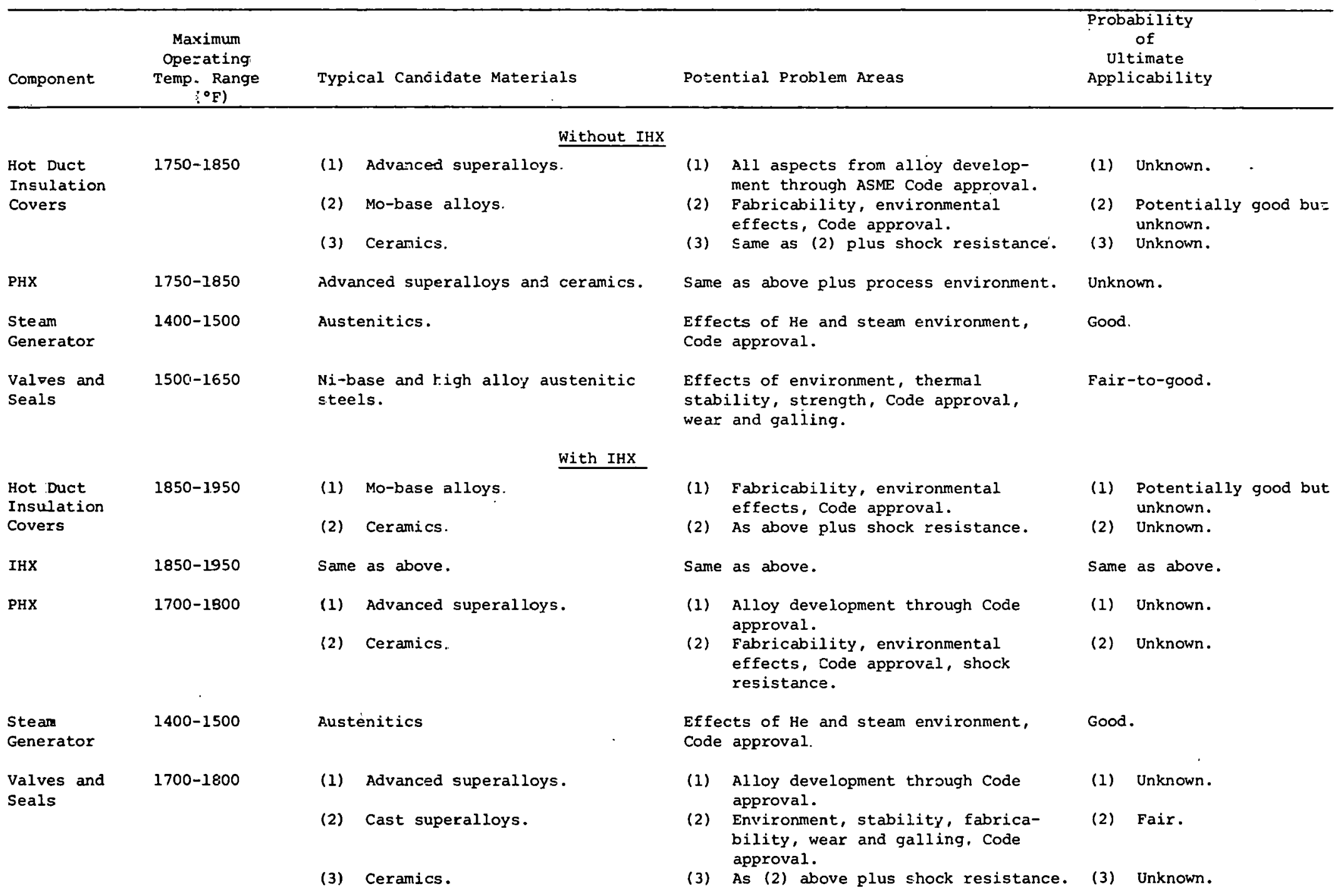


Table 13

Aaterial Candiates for Critical Components of

$1800^{\circ} \mathrm{F}$ and $2100^{\circ} \mathrm{g}$ Process Temperature VHTR

\begin{tabular}{|c|c|c|c|c|}
\hline Component & $\begin{array}{l}\text { Maximum } \\
\text { Operatir:g } \\
\text { Temp. Range } \\
\left.\text { ( }{ }^{\circ} \mathrm{F}\right)\end{array}$ & Typical Candidate Materials & Potential Problen Areas & $\begin{array}{c}\text { Probability } \\
\text { of } \\
\text { Ultimate } \\
\text { Applicability }\end{array}$ \\
\hline
\end{tabular}

Without IHX $\left(1300^{\circ} \mathrm{F}\right)$

\begin{tabular}{|c|c|c|c|}
\hline $\begin{array}{l}\text { Hot Duct } \\
\text { Insulation } \\
\text { Covers }\end{array}$ & $1950-2050$ & $\begin{array}{l}\text { (1) } \\
\text { (2) }\end{array}$ & Mc-base alioys. \\
\hline
\end{tabular}

(1) Fabricability, ervironmental effects, Code approval.

(2) Sarre as (1) above plus shock resistance.

(1) Potentially good, but unknown.

(2) Unknown

Same as (2) above plus process erviron- Unknown. ment compatibility.
(1) Alloy development through Code approval.
(2) Environment, stability, fab ßica- bility, wear and gallirg, Code approval.
(3) As (2) above plus shock resistance. (3) Unknown.
(4) As (2) above.

\author{
(1) Unknown \\ (2) Fair.
}

(1) Aivanced superalloys.

(2) Cast superalloys.

13) Ceramics

14) Mo-base alloys.

\section{With IHX $: 1800^{\circ} \mathrm{F}$ )}

Hot Duct 2050-2150 Insulation Cover:

Same as hot juet without IHX.

Same as hot duct without IH:.

IHX

2050-2150

PHX

$1900-2000$

Valves and 1900-2000 Seals

Same as above.

Ceramics.

(1) Cast suferalloys.

(2) Mo-base alloys.

(3) Ceramics.

Same as above.

Same as PHX without IHX.

(I) Same as valves and seals witrout IHX plus strength.

(2) As without IBX.

(3) As without IHX.

With and Without IHX $\left(2000^{\circ} \mathrm{F}\right)$

Hot Duct 2250-2350 Insulation Covers

IHX

$2250-2350$

PHX

$2100-2200$

$(2150-2250)$

Valves and 2100-2200

Seals (1950-2050)
Ceramics and Mo-base alloys.

Same as above.

Ceramics.

\section{fill problem areas apply, Etrength of}

No-base suspect at upper end.

Same as above.

All problem areas apply.
Same as valves and seals for $1800^{\circ} \mathrm{F}$ process temperature with IfZ.
Same as hot duct without IHX. Same as above.

Unknown.

(1) Poor-to-fair.

(2) Poor-to-unknown.

(3) Unknown

Unknown.

Unknown.

Unknown 


\section{Fission Product Behavior Aspects}

Fission products enter the coolant circuit of an operating HTGR by one of three general mechanisms. The most direct of these concerns volatile fission products which are born as a result of uranium contamination of surfaces; these species enter the coolant circuit with virtually no attenuation. A second mechanism involves release from coated fuel particles in which the effectiveness of the protective coatings has in some manner been compromised. Such a loss in coated particle integrity may result in the fabrication process, or to the combined influence of thermal and mechanical stresses on otherwise sound coatings or on coatings that have been weakened as the result of irradiation or chemical effects. The third mechanism for release involves transport through physically intact particle coatings. Obviously, not all three generalized mechanisms are significant in a practical sense for all fission products of interest. For example, transport of krypton or xenon through intact coatings does not take place and can be safely ignored as an influence on coolant circuit inventories of these fission products, yet diffusion through coatings can dominate control of cesium inventories.' In a similar vein, the significance of release of a particular fission product need not directly involve radiological considerations. The stable fission product barium nuclides, for example, can appreciably influence effects of steam ingresses. Similarly, fission product tellurium offers the potential for attack of metallic components, regardless of radiological factors. Additionally, rare earth fission products are known to attack SiC coatings of TRISO fuel particles and thus become significant in terms of providing a mechanism for fuel failure.

Fission products enter the coolant circuit as volatile species and as species attached to otherwise inert debris. The relative magnitudes of these two types of distribution are in general unknown, and probably vary widely from reactor system to reactor system. It is also significant to note that species attached to mobile debris provide a mechanism for dispersal of normally very stable chemical forms (which may possess high radiological toxicity). The manner by which the fission products enter the coolant circuit will likewise determine their distribution in and removal from the circuit, and this can be a major concern relative to maintenance. 
Transport of fission products along the release pathway into the coolant circuit, and in a large measure the distribution along the coolant circuit, is primarily a temperature-dependent process. Fuel failure mechanisms, on the other hand, exhibit a complex interrelationship between temperature, temperature gradient, irradiation history, chemical composition, and possibly, time.

All designs attempt to maintain fission product transport at an acceptable level by limiting fuel temperature and by providing gas cleanup systems. The $G A$ and $G E$ designs provide an unfueled graphite barrier between fuel kernels and coolant. Irradiation experience in the AVR, in the Peach Bottom HTGR, and in test loops indicates that the fission product content of the coolant is low. Nevertheless, the designer must carefully consider potential fission product release paths, both during normal operation and following failures.

Tritium is another radioactive species formed in gas-cooled reactors. Tritium is formed in the HTGR system in three ways: by ternary fission in the core, by neutron reaction with lithium impurities in core materials, and by neutron reaction with $\mathrm{He}-3$ in the helium coolant. Tritium from the first two sources is largely retained within the coated fuel particles, so that the He- 3 reaction becomes the principal source of tritium in the coolant. Tritium can diffuse through the tubes of a methane-steam reformer, posing a threat of contaminating the process stream. If the tubes contain an adherent oxide film, the tritium permeation rate would be very low. Some of the reactor designers believe that an oxide film can be maintained and that a methane reformer in the primary helium circuit is feasible. Others, such as the Japanese, have assumed that an intermediate heat exchanger will be necessary. The IHX should eliminate the tritium uncertainty since additional barriers would be placed between the primary heliurl and the process, and the secondary coolant chemistry could be controlled. Considerably more analysis of this problem is required. 


\section{E. Safety and Environmental Considerations}

\section{Licensing Process}

Prior to the licensing of a reactor for construction, it is necessary for the applicant to submit a preliminary safety analysis report (PSAR) and an environmental report (ER). These reports must prove the feasibility of the proposed nuclear system to operate within legal and regulatory constraints at the proposed site. Prior to the granting of an operating license, a final safety analysis report (FSAR) and final environmental impact statement (EIS) are issued and approved. The nuclear coal conversion system will have to go through this regulatory process. Emphasis in the PSAR and the FSAR will be on the nuclear reactor, but it will be necessary to show that the coal process does not reduce nuclear safety factors. The $E R$ and the EIS will have to deal with all impacts of the nuclear coal conversion system, will have to demonstrate there is a demand for the products of the system that can best be supplied by the proposed facility, and that the benefits of the system exceed the costs.

Gas-cooled reactors are inherently safe because:

1. Failure of the PCRV containing the reactor is not credible. An overpressure (from no credible cause) would release gas pressure and then the crack would "heal" via continued tension in the tendons. Fuel would be contained.

2. The core is large and all-ceramic. Several hours are available following an accident to establish circulation within the reactor for removal of afterheat.

3. Some designs remove afterheat by natural circulation.

4. The reactor has a strong negative temperature coefficient of reactivity and is therefore very stable.

Wille the VHTR will operate at a higher temperature than the steamgenerating gas-cooled reactor, safety considerations are expected to be similar. Development of the HTGR for power production should assure resolution of most of the safety and environmental questions pertaining to the VHTR. Additional safety analysis will be required during the development process and for licensing, however. 


\section{Types of Accidents which Must be Considered}

a. Design Basis Depressurization Accident. The catastrophic failure of the primary coolant boundary is considered incredible, since neither the prestressed concrete reactor vessel (PCRV) penetration closures nor the PCRV itself is susceptible to catastrophic failure. However, the design basis depressurization accident (DBDA) is assumed to be the depressurization of the primary coolant system through a $100-i n .^{2}$ flow area at any of the possible locations. An investigation of the consequences of depressurization originating at various locarions for the sleum-generating IITCR indicates that failure at the hot portion of the cycle results in the highest containment pressures, containment temperatures, activily lelease from the rCRV, and hence largest offsite doses. For this reason, the process heat reactor DBDA might be assumed to occur from a break where the reactor outlet gas can be discharged to the containment.

The analysis developed by GA was based on their standard process heat plant with $1600^{\circ} \mathrm{F}$ reactor outlet temperature $\left(\sim 1400^{\circ} \mathrm{F}\right.$ process temperature).

The expected mode of operation during a DBDA is for continued reactor core cooling using the main loop circulators driven initially by nuclear steam. In an HTGR steam plant, complete flood-out of the stean generators occurs in the first few minutes of the transient. Steam from the rlash tanks can be used to drive the circulators for several more minutes. At this point, auxiliary steam is required to continue with main 100 p cooling. Alternatively, the core auxiliary cooling system (CACS) is initiated to supply core cooling. A similar scenario is expected fur lie process heat HTER.

The GA analysis of the DBDA indicates that radioactive releases to the environment results in doses at the exclusion area boundary and the low population zone boundary that are significantly less than the guidelines of 25-rem whole body and 300-rem thyroid given in $100 \mathrm{CFR} 100.40$ The analysis also indicates that the temperatures and pressures in the reactor containment during and after the accident do not exceed the design values. These analyses must be refined and reviewed as part of the reactor design effort. 
Adequate forced circulation core cooling is maintained following the depressurization by use of main loops or the auxiliary loops operating with reduced primary coolant density. No damage to either main or auxiliary circulators occurs during the depressurization.

b. Loss of Main Loop Cooling. In the unlikely event that primary loop cooling is lost, GA provides a CACS. The CACS utilized for the process heat HTGR is similar to the design developed for the steam-generating HTGR. The CACS consists of multiple parallel loops, each containing an auxiliary heat exchanger, an auxiliary circulator (electric motor driven), and appropriate helium ducting and valves. The water side of the heat exchanger includes pumps, reject heat exchangers, and various instrumentation and water quality equipment. Onsite auxiliary power systems are provided to ensure an adequate supply of electrical power. For a $3000 \mathrm{MW}(t)$ reactor, three $50 \%$ capacity loops are supplied. Satisfactory cooldown is obtained using any two of the three loops. The average core outlet temperature peaks at about $1700^{\circ} \mathrm{F}$, well below any hazardous condition.

The PBR has comparable safety systems to limit core temperature. In the event of failure of all safety systems, core temperature will rise to about $2000^{\circ} \mathrm{C}$ in 6 hours and heat will be removed by natural circulation to the cooled pressure vessel liner.

c. Product Contamination. In the case of systems where the process heat exchanger is in the primary vessel, one must anticipate the sudden failure of a tube. In that event, an increase of radioactivity would be detected and valves would close to isolate the affected heat exchanger. The contaminated gases would be discarded through the radwaste system.

d. Process Leak to Containment. The process gas contains methane and hydrogen. It a reformer inlet or outlet line fails in an uninerted containment, there could be an explosive mixture in the containment. if proper precautions are not taken. The simplest precaution is to ensure 
that adequate steam is always present in the process stream to prevent the formation of an explosive mixture. A further possibility is to use only double-walled pipes in the containment. Then, if one pipe failed, the backup pipe would contain the gas and via pressure signals inform the plant operator or plant protection system to shut down and/or add explosion retardents to the loop feed lines. As a final alternative, the containment could be inerted with nitrogen. However, this solution has significant disadvantages in terms of maintenance procedures. Nonetheless, it is important to note that the potential hazard of having combustible material in the containment can be safely controlled by various methods.

e. Steam Ingress Considerations. Steam ingress into the primary coolant circuit of a VHTR must be viewed in terms of two time frames. Effects of sudden large inleakages are generally of a short-term nature. These include possible'interactions with exposed fuel, fission products, and coolant circuit surfaces, which could increase gas-borne fission product inventory; reactions with graphite moderator and structural materials, which could result in the generation of explosive concentrations of hydrogen and carbon munuxile and/or rccult in the inss of structural integrity; and reactions with neutron poisone, such as horon carbide or trifluoride, which could negate the intended shutdown functions of systems using these poisons.

Effects of small, continuous inleakages, on the other liald, must be regarien sver a time period that spans the life of the reactor. Two areas of primary concern in this regard have been identified; one involves the gradual, uniform erosion of structural graphite which can result in the sudden collapse of a stressed number, whereas the second concerns weakening of metallic members through carburization involving reaction product $\mathrm{CO}$, and consequent large steam ingresses in those cases in which the carburized members isolate the primary coolant from steam. 
The steam-graphite reaction is endothermic, hence removal of the source of heat is a most effective technique to limit effects of large steam ingresses. Air oxidation of graphite, on the other hand, is exothermic; as a result, this type of oxidation mechanism is more difficult to control. With respect to the VHTR system, however, air ingress is much less likely than steam inleakage, and for those cases in which air ingress is possible (all of which involve primary coolant system depressurization), the effects are predominantly determined by the rate of air inleakage rather than reaction kinetics.

The high temperatures of the VHTR greatly increase the rate of these reactions. While the total amount of graphite reacted may not be greatly affected by the temperature level (it is controlled more by the amount of water ingress), the VHTR reaction may be more localized at the point of steam entry.

The $\mathrm{W}$ concept eliminates the steam ingress problem by eliminating steam generators in the primary system.

\section{Types of Environmental Impacts Which Must Be Considered}

a. Radioactivity Emission to Environment. The VHTR must contain the radioactive species to an extent which satisfies regulatory requirements. Experience gained with HTGR containment should be directly applicable. While the fission product content of the VHTR coolant will probably be higher than that of gas-cooled power reactors, the emissions from properly designed VHTRs should be comparable.

b. Radioactivity in Product. Steady state leakage of reactor coolant and/or tritium leakage and diffusion will result in a very small level of radioactivity in the product. The vendor studies and German reports indicate that steady state radiation doses to the general public resulting from a nuclear coal gasification plant would be well within all existing NRC regulations and guidelines, and would in fact be negligible.

c. Impacts of the Nuclear Fuel Cycle. These impacts result from uranium mining, processing, enrichment, fuel transport, fuel fabrication, fuel reprocessing, fuel recycle and ultimate waste storage. The impacts of nuclear coal conversion will be to somewhat increase the number and/or the size of nuclear fuel cycle facilities. A secondary effect will be much 
greater emphasis on fuel cycle operations characteristic of gas-graphite reactors, e.g., the thorium-U $\mathrm{U}_{233}$ cycle.

Perhaps the greatest long-term impact of the VHTR would be a continuing strong demand for enriched uranium fuel after breeders dominate the electric power industry. This demand could be satisfied by a higher rate of uranium mining and/or from fuel bred in the breeder reactors.

d. General Impacts of Nuclear Coal Conversion Systems. The nuclear coal conversion system has cumulative impacts on land, water, air and society which must be compared to the impacts of alternatives. There are clearly advantages with respect to the amount of coal mining and transport disturbance, and from less air pollution. Disadvantages accrue from the impact of a larger national nuclear fuel cycle and from the local nuclear safety risks.

\section{F. Coupling of Reactor and Process: Potential Need for an Intermediate Heat Exchanger (IHX)}

The decision on whether to use an IHX has important repercussions on feasibility, cost, and safety/environmental effects. These questions are sufficiently complex thät a good deal of Lime, and posoibly come actual licensing actions, will be required for complete resolution.

Proponents of the methane-steam reformer type of coupling have concluded that this process can be carried out without an IHx. ${ }^{1,5}$ Their analysis shows that the radioactivity in the product gas is negligible and that the reactor safety problems can be resolved.

The other nuclear coal process couplings, steam-coal gasifiers and thermochemical hydrogen process, are believed by all to require IHXs. The failure of process heat exchangers in these systems could significantly damage the reactor.

The advantages of having an IHX are the following:

1. Reduce or eliminate the transport of radioactivity into the product.

2. Reduce or eliminate the ingress of water and hydroyen into the reactor.

3. Improve maintainability of the process heat exchanger.

4. Reduce reliability demanded of PHX. 
5. Reduce possible hazardous interactions of process and nuclear plant, such as explosions which could damage reactor equipment.

6. Reduce size of the PCRV and possibly of PCRV penetrations.

Disadvantages include:

1. The cost. Process heat costs may be increased by $20 \%$.

2. Need to develop higher-temperature materials (by $50^{\circ} \mathrm{C}-100^{\circ} \mathrm{C}$ ) for the primary system, to achieve the same process temperature.

3. Need to develop the IHX and high-temperature containment valves operating in the secondary helium.

4. More operating components, increasing probability of plant outages.

5. Lower efficiency.

The analysis of IHX is further complicated by the spectrum of choices between a "pure" primary process HX and a "pure" IHX. This spectrum includes at least the following:

1. Primary PHX inside the reactor vessel.

2. Primary PHX inside the containment building but outside the reactor vessel. This would improve maintainability.

3. IHX-PHX inside the reactor vessel consisting of double-walled tubes with helium pressure in between. ${ }^{41}$ This would reduce steady-state material transport between process and nuclear systems, but may not improve safety scenarios.

4. IHX for process, but steam generator still inside the reactor vessel and directly coupled.

5. IHX inside PCRV, and PHX inside containment vessel.

6. IHX inside PCRV, PHX and steam generator outside containment vessel ("pure" IHX system).

\section{ECONOMICS \\ A. Process Heat Cost}

Oak Ridge National Laboratory, with assistance from United Engineers and Constructors, has estimated VHTR process heat cost. Figures 12 and 13 give the range of estimated costs of nuclear process heat when supplied from a $3000 \mathrm{MW}(t)$ VHTR, considering the presence or absence of an intermediate heat exchanger as a parameter. The economic ground rules used in obtaining these estimates are given in Table 14 . 


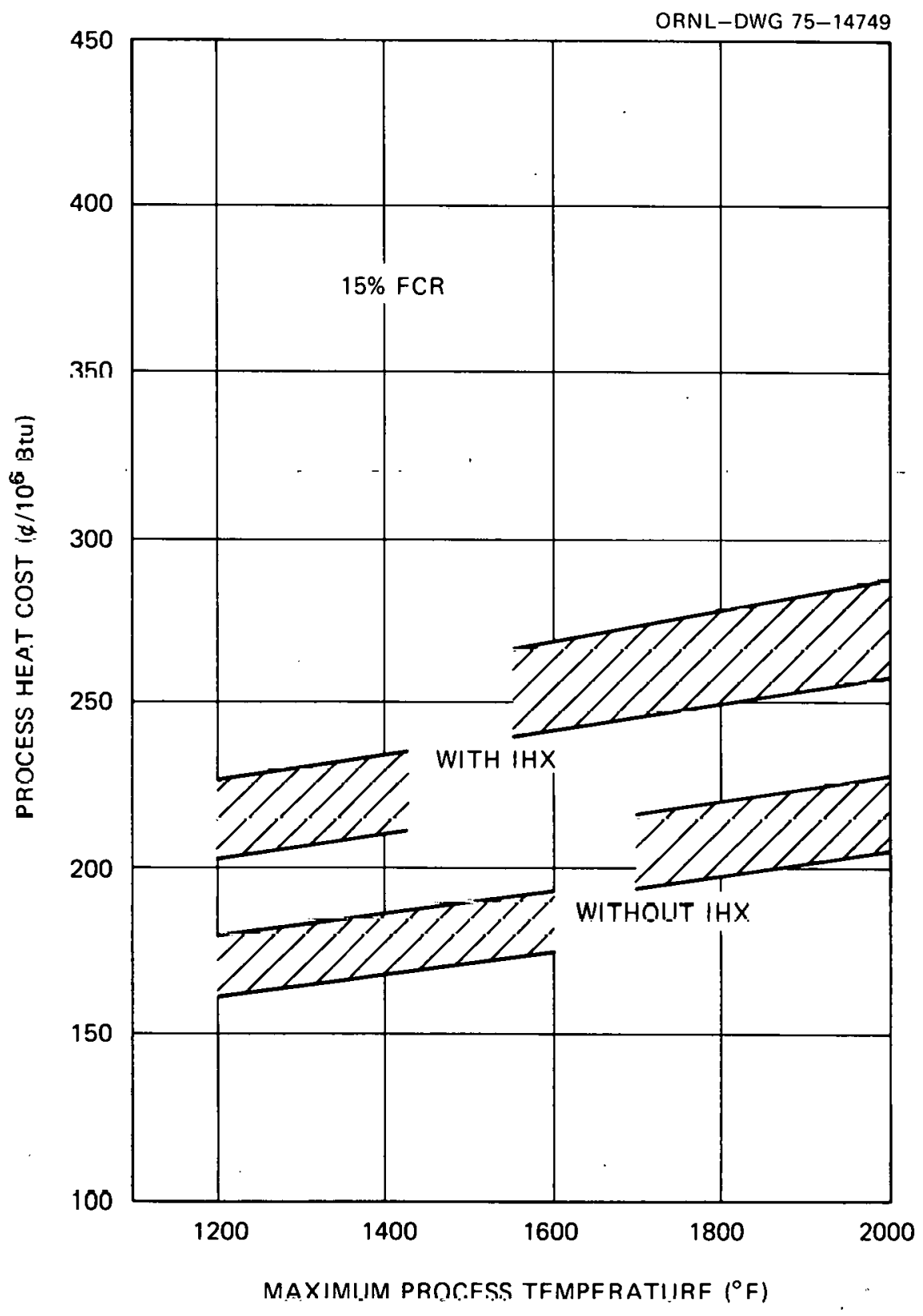

FIGURE 12. Process Heat cost from a VHTR vs Maximum Process Temperature, Utility Financing 


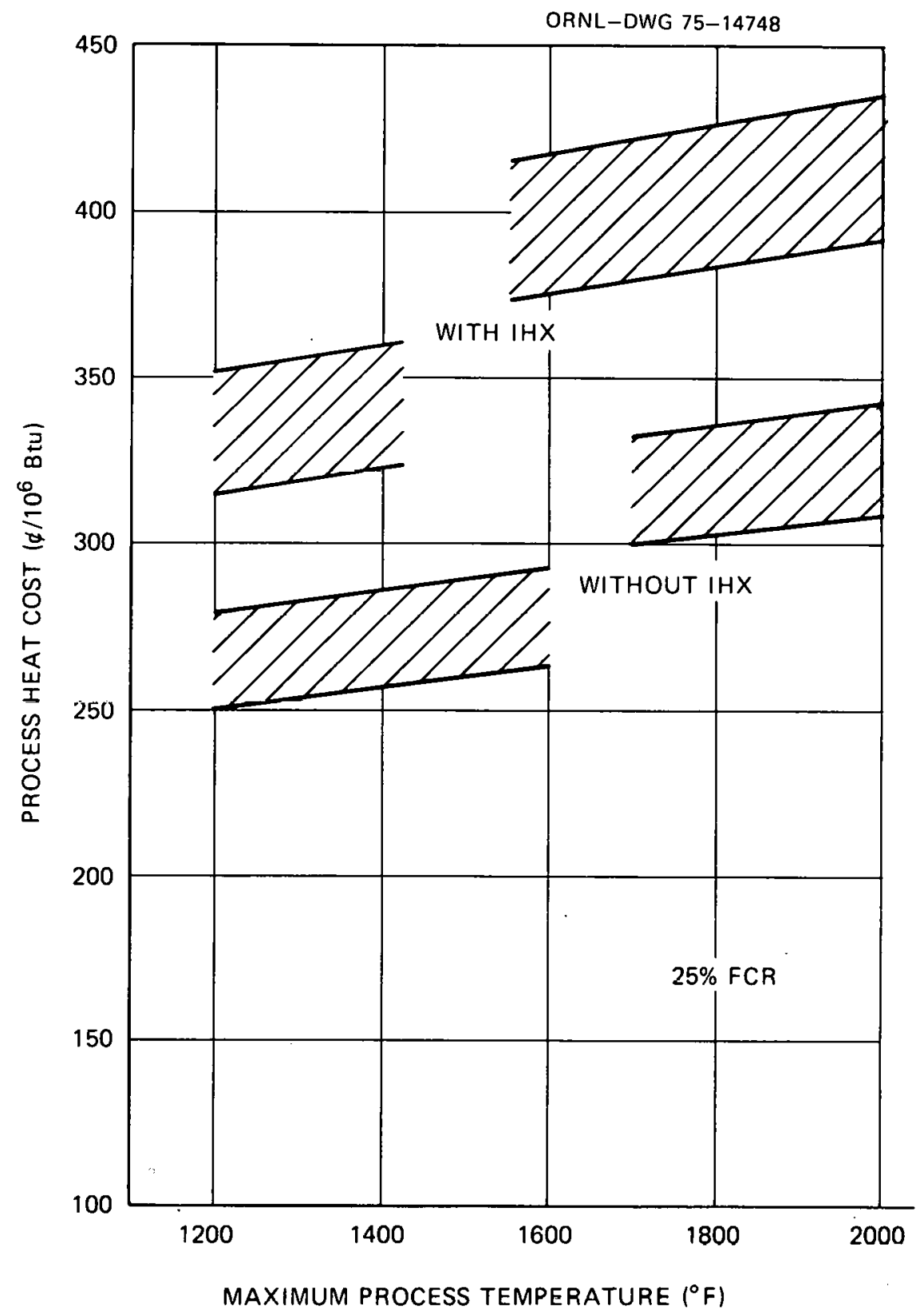

FIGURE 13. Process Heat cost from a VHTR vs Maximum Process Temperature, Industrial Financing 
Table 14

Economic Ground Rules Employed in VHTR Evaluation

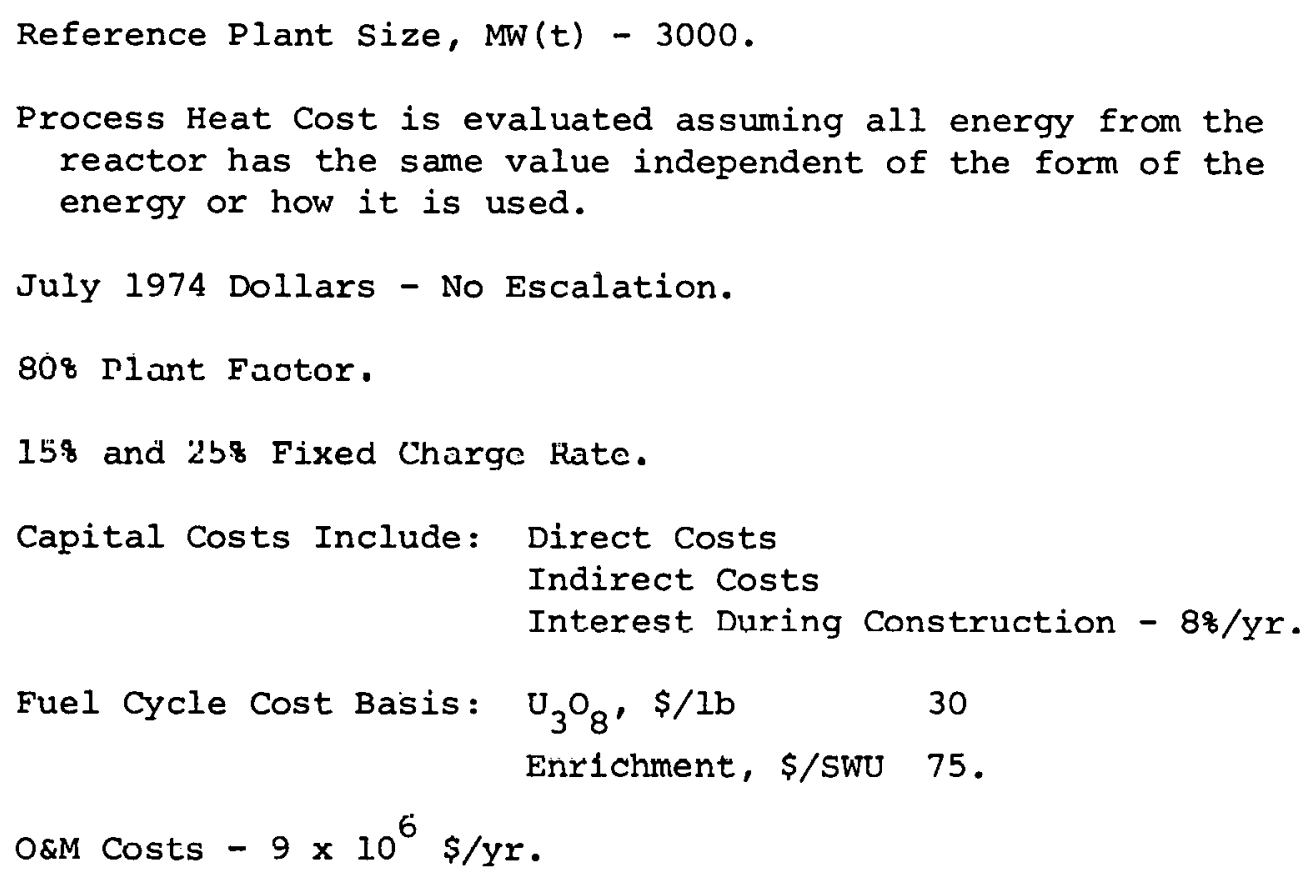

These costs are based on preliminary, conceptual designs, and rely heavily on vendor information. The costs which are presented may change as a result of further research and development and of more detailed design. The general trend of increasing heat cost with increasing temperature results from increased costs of materials and components, and more elaborate systems to maintain the fuel at acceptable temperatures. The discontinuity in cost above $1600^{\circ} \mathrm{F}$ process temperature stems from the need to introduce exotic high temperature alloys and/or ceramics into the high temperature components.

While process heat costs increase with temperature, the usefulness of the process heat is also increased. Table 15 illustrates the effect of maximum process temperature on the efficiency of a typical nuclear coal conversion process (production of hydrogen via the General Atomic/stone and Webster process). Efficiency is expected to increase from $52 \%$ at $1200^{\circ} \mathrm{F}$ maximum process temperature to 698 at $2000^{\circ} \mathrm{F}$. 
Table 15

Estimate of the Efficiency of Hydrogen Production Plants Using the General Atomic/Stone and Webster Process (from Ref.41)

Maximum Process Temperature, ${ }^{\circ} \mathrm{F} \quad 1200 \quad 1400 \quad 1600 \quad 1800 \quad 2000$

Heat Inputs, $10^{9} \mathrm{Btu} / \mathrm{hr}$,

$\begin{array}{lrrrrr}\text { Nuclear } & 10.24 & 10.24 & 10.24 & 10.24 & 10.24 \\ \text { Coal } & 9.76 & 18.47 & 19.40 & 20.85 & 21.79\end{array}$

Hydrogen Production Rate,

\begin{tabular}{|c|c|c|c|c|c|}
\hline $\operatorname{Mscfd}(a)$ & 530 & 763 & 882 & 949 & 1092 \\
\hline $10^{9} \mathrm{Btu} / \mathrm{hr}$ & 8.53 & 15.04 & 16.57 & 17.66 & 18.78 \\
\hline Iuid Fuels Production, & 1.47 & 2.76 & 2.86 & 3.09 & 3.23 \\
\hline
\end{tabular}

$10^{9} \mathrm{Btu} / \mathrm{hr}$

Export Electric Power, MW

Efficiency, \& (b)

$\begin{array}{lllll}138 & 57 & 31 & 18 & 7\end{array}$

$\begin{array}{lllll}52 & 63 & 66 & 67 & 69\end{array}$

(a) At $32^{\circ} \mathrm{F}, 1$ atmosphere.

(b) Defined as fuel and electricity outputs/heat inputs.

The effect of size on energy cost is given in Fig. 14. A recent design study by GE of a $500 \mathrm{MW}(t)$ PBR heat source indicated heat costs in the range of $\$ 4$ to $\$ 6 / 10^{6} \mathrm{Btu}^{42}$ There is clearly a significant advantage of scale in VHTR process heat cost.

The foregoing estimates may be compared with estimates of process heat cost using oil and coal shown in Figs. 15 and 16, respectively. The process heat costs displayed in Figs. 12 to 16 do not take into account the relative usefulness of the process heat delivered from the respective sources. Generally, nuclear process heat is expected to be competitive with oil, and competitive with coal in many locations.

Another important aspect of VHTR economics is that the capital cost predominates in relation to fuel cost, as indicated in the following breakdown of costs of a $3000 \mathrm{MW}(t)$ plant (with IHX, $1600^{\circ} \mathrm{F}$ process):

\begin{tabular}{|c|c|c|c|c|}
\hline & \multicolumn{2}{|c|}{$158 \mathrm{FCR}$} & \multicolumn{2}{|c|}{$258 \mathrm{FCR}$} \\
\hline & $\xi /$ MBtu & 8 & \&/MBtu & 8 \\
\hline Capital Cost & 167 & 74.5 & 278 & 80.5 \\
\hline O\&M & 13 & 6 & 13 & 4 \\
\hline Fuel Cycle & 44 & 19.5 & 54 & 15.5 \\
\hline Total & 224 & 100 & 345 & 100 \\
\hline
\end{tabular}




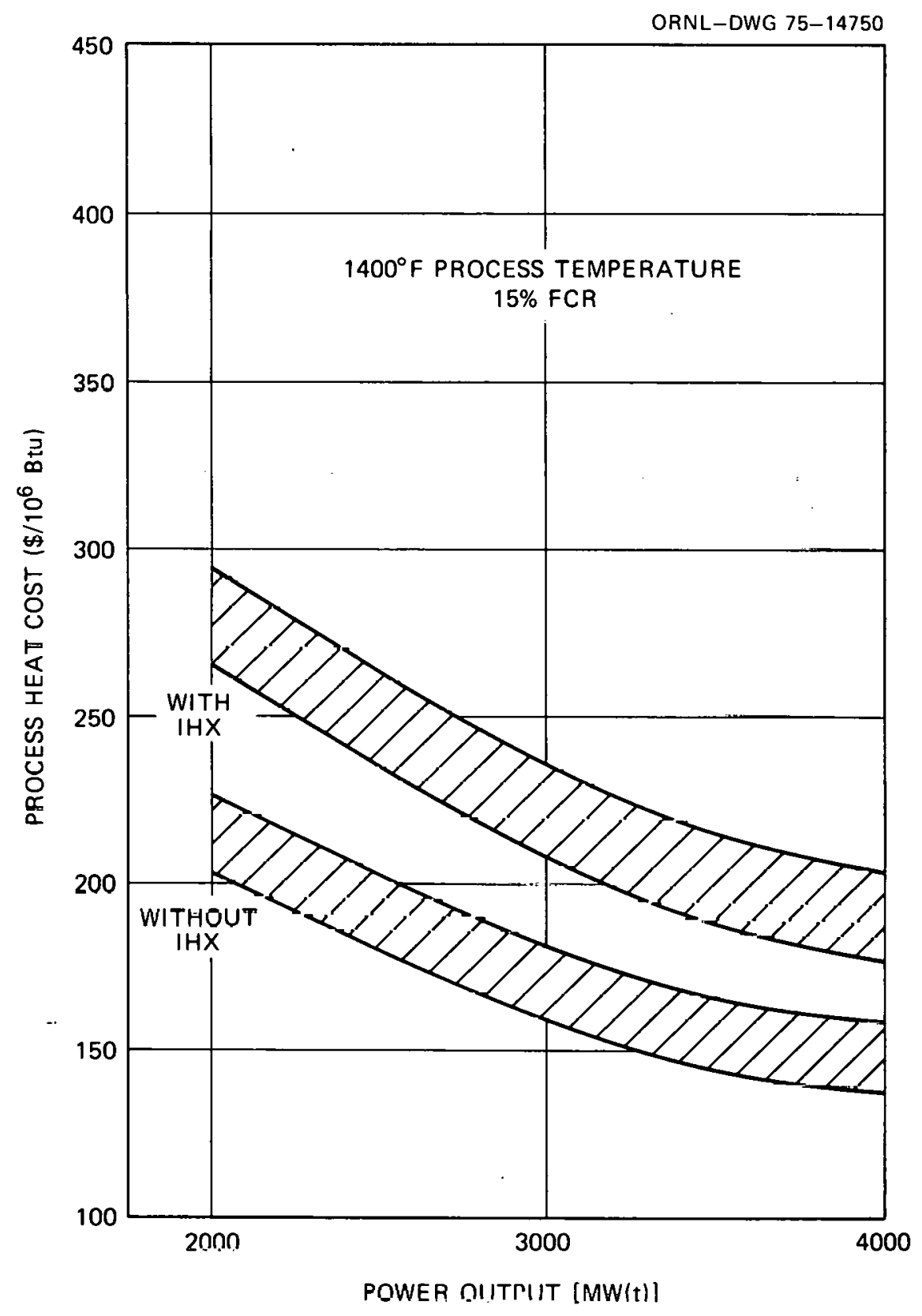

FIGURE 14. Effect of Size on Energy Costs 


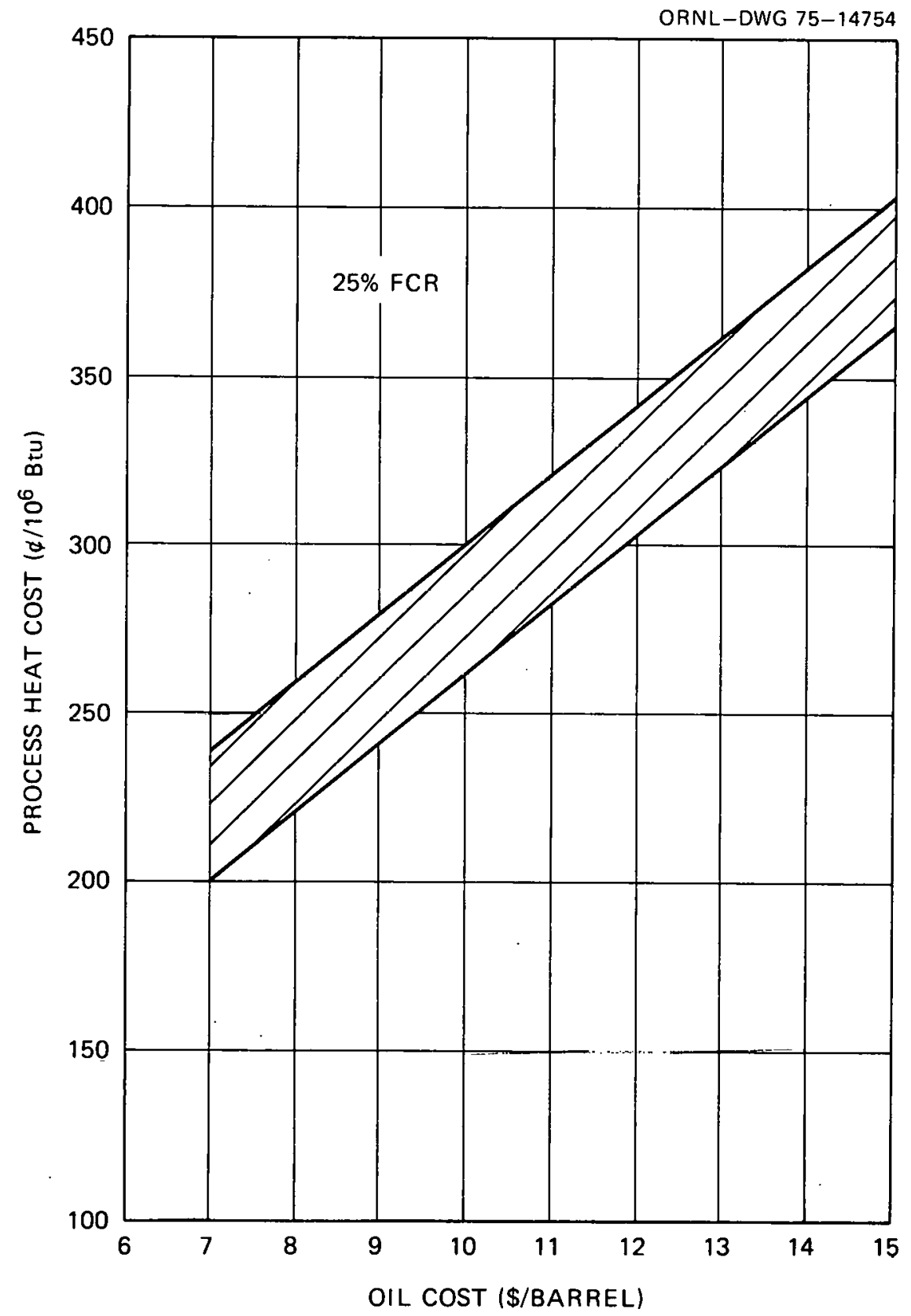

FIGURE 15. Cost of Process Heat from an Oil-Fired Process Heater 


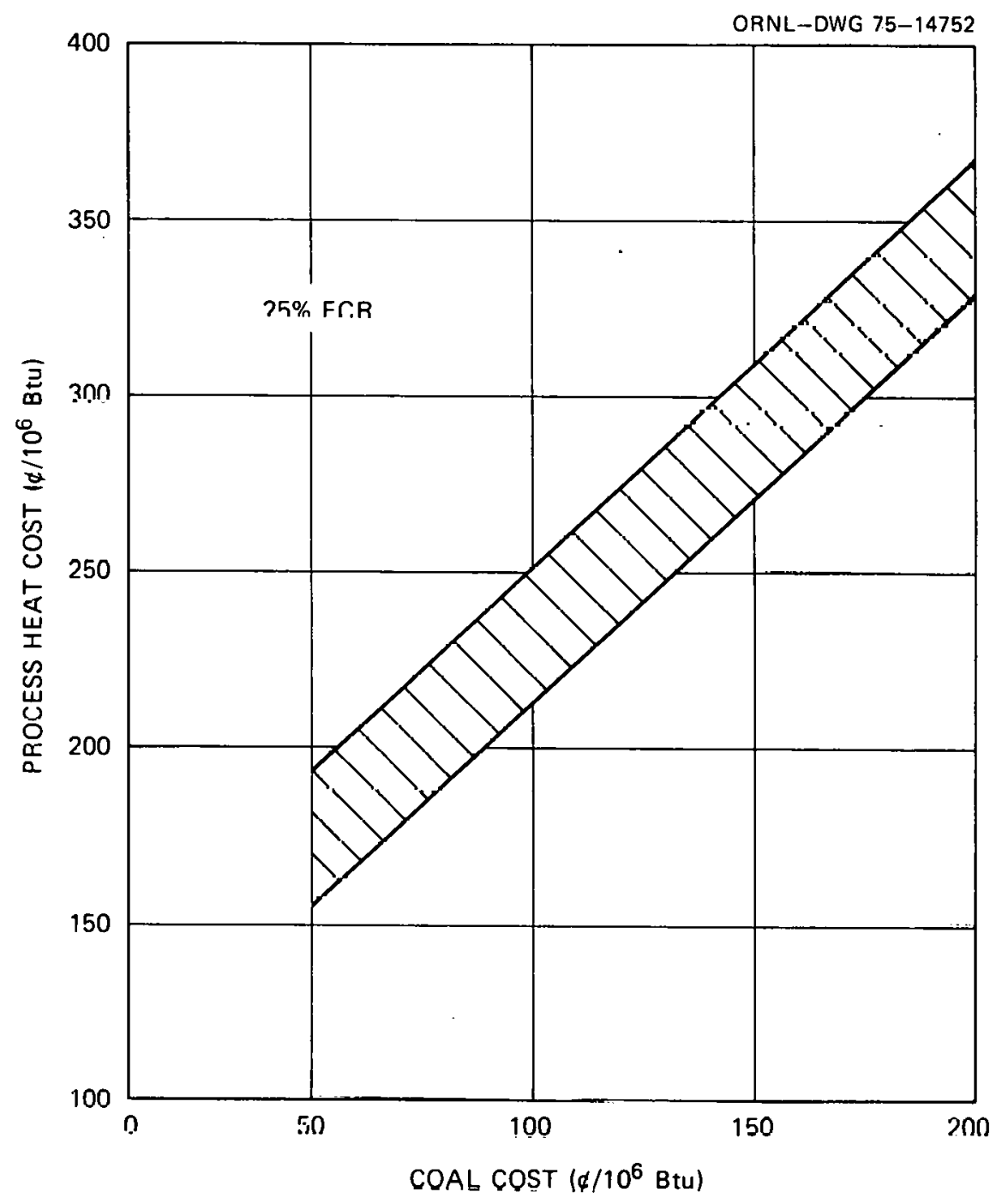

FIGURE 16. Cost of Process Heat from a Coal-Fired Process Heater 


\section{B. Fuel Cycle Considerations}

1. The Thorium-Uranium Fuel Cycle

The gas-graphite reactor is an efficient converter reactor and is extremely flexible with regard to use of alternative nuclear fuels. The fuel cycle most commonly proposed by GA and by the German developers of these reactors is the thorium-uranium cycle (Fig. 17). This fuel cycle has the advantages of lowest cost and of higher conversion ratio of fertile $\mathrm{Th}$ to $\mathrm{U}_{233}$ fuel in comparison to the conversion of fertile $\mathrm{U}_{238}$ to plutonium, based on a developed fuel recycle technology. This is due to the superior nuclear characteristics of $\mathrm{U}_{233}$ relative to either $\mathrm{U}_{235}$ or plutonium in the neutron energies typical of gas-graphite reactors.

The problems of fuel element preparation and design have been thoroughly addressed. Fuel elements have been fabricated by commercial vendors for both HTGR and PBR designs. These elements perform well in reactors. The fabrication of graphite fuels at costs assumed in the economic analysis will require the establishment of large-scale manufacturing facilities. The reprocessing of spent graphite fuels requires a special head-end process to extract fuel materials and fission products quantitatively and to put them into aqueous solution. This is followed by a relatively conventional solvent extraction process to separate uranium, thorium and fission product wastes.

The fuel recycle step is a difficult one in that the bred $\mathrm{U}_{233}$ is contaminated with $\mathrm{U}_{232}$, whose daughters are highly radioactive, requiring remote handling behind shielding. ERDA has built some applicable laboratory facilities at Oak Ridge, and is considering a proposal for the construction of a pilot plant.

Ultimate waste disposal from the uranium-thorium cycle would be similar to that from light-water reactor fuel cycles. There would probably be fewer long-lived actinide isotopes to store. ERDA currently is speeding up the development of waste disposal facilities for all nuclear fuels.

\section{Alternate Fuel Cycles}

Another fuel cycle for the VHTR would involve use of slightly enriched uranium fuel as proposed by $\mathrm{GE}^{2}$ This fuel cycle produces some plutonium in the spent fuel. This approach could make use of some light-water 
ORNL-DWG 75-14755

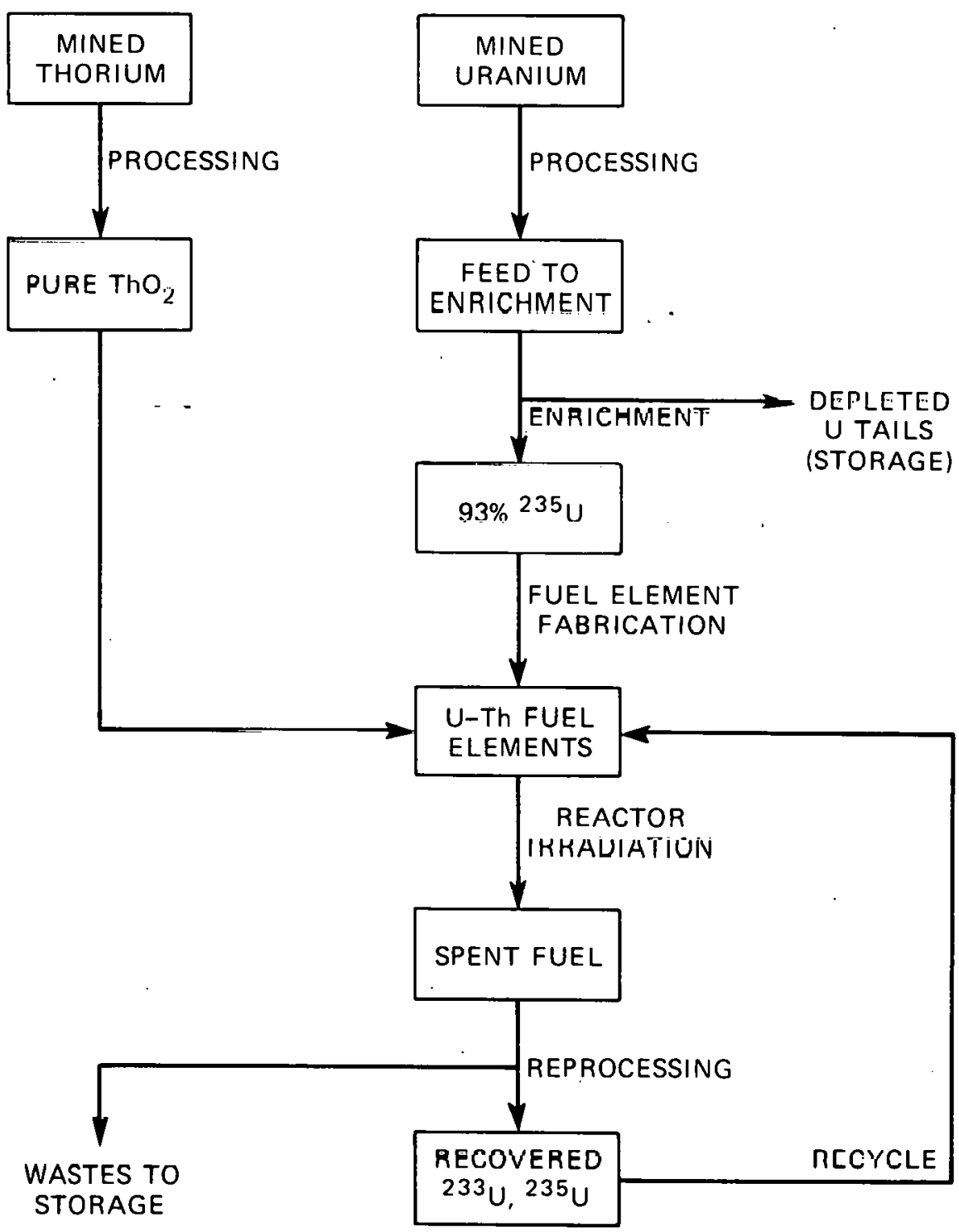

FIGURE 17. Thorium-Uranium Fuel Cycle 
reactor fuel cycle facilities, but fuel fabrication and spent fuel dissolution facilities would be similar to those of the thorium-uranium cycle. Another option would be indefinite storage of the spent fuel.

A higher conversion ratio thorium-uranium cycle is possible by increasing the thorium-uranium loading in the core, or by a combination of increasing the refueling frequency, decreasing the fuel's final burnup and some increase in the thorium loading. These systems would have higher fuel inventory but lower net fuel depletion. The greater throughput rates caused by the decrease in fuel residence time will cause increases in the fabrication and reprocessing costs. The higher conversion ratio systems may become the most economic approach when uranium is more valuable than at present, and after the uranium recycle step is fully commercialized, but this is dependent upon inventory charge rate.

Gas-graphite reactors can also accept plutonium fuels, particularly as mixed with thorium.

\section{Fuel Cycle Parameters and Economics}

The gas-graphite reactors are intermediate in fuel economy between light-water reactors and the LMFBR as shown in Table 16.

Uranium is currently being priced in the range of $\$ 20$ to $\$ 40 / 1 \mathrm{~b} \mathrm{U}_{3} \mathrm{O}_{8}$. There is considerable uncertainty in the extent of U.S. uranium resources. The exploration for additional natural uranium ore in the United States, a cooperative effort between industry and ERDA staff and laboratories, has been speeded up. The National Uranium Resource Evaluation (NURE) program is well established and preliminary reassessments of uranium resources in about 30 of the 43 uranium districts have been completed using knowledge of the geology of uranium, previous evidence of uranium occurrences, and evidence other than that obtained from drilling. This preliminary phase will be completed for the United States in 1976. By 1980, the preliminary information will be partially confirmed by drilling. 
Table 16

Typical Reactor Fueling Requirements and Costs

\begin{tabular}{lccc}
\hline $\begin{array}{l}\text { Reactor } \\
\text { TyPe }\end{array}$ & $\begin{array}{l}\text { Specific } \\
\text { Invontory } \\
\text { Fisjilc/MW(t) }\end{array}$ & $\begin{array}{c}\text { Conversion } \\
\text { Ratio }\end{array}$ & $\begin{array}{c}\text { Typical Fuel } \\
\text { Cycle Cost* } \\
\text { i,/MBtu }\end{array}$ \\
\hline Light-Water Reactor & 0.85 & 0.6 & 40 \\
HTGR-U2 33 Recycle & 0.6 & 0.65 & 42 \\
HTGR-No Recycle & 0.7 & 0.6 & 44 \\
HTGR-High Conversiona & $0.7-1.0$ & 0.8 & $40-51$ \\
LMFBR & 0.80 & 1.15 & 15 \\
\hline
\end{tabular}

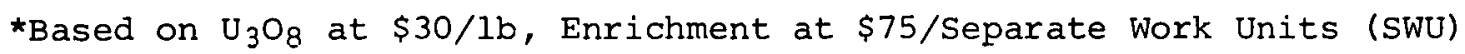

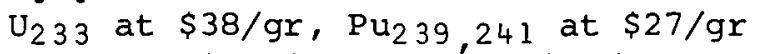

Fuel Fabrication - LWR - $\$ 75 / \mathrm{kg}$ HTGR - $\$ 300 / \mathrm{kg}$

Fuel Reprocessingb - $\$ 120 / \mathrm{kg}$ LMFBR - $\$ 250 / \mathrm{kg}$

Utility Finance Basis

aThe lower values are estimated if refueling frequency can be increased without significant downtime penalty. The higher values are estimated for systems in which the conversion ratio is increased by increasing the thorium loading.

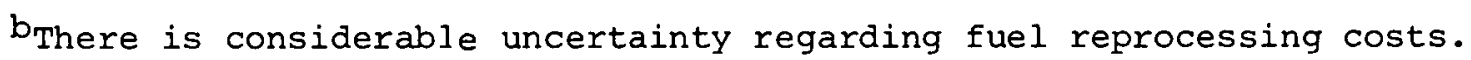
The value of $\$ 120 / \mathrm{kq}$ was a ground rule. in the vendor studies. Real costs will almost certainly be higher than this. 
A recent estimate of the U.S. uranium resourcesis shown in Table 17.43 In addition to the uranium shown in Table 17, there is about 5 million tons of $\mathrm{U}_{3} \mathrm{O}_{8}$ available from Chattanooga shale at a cost of about $\$ 100 / 1 \mathrm{~b}$. It is

Table 17

U.S. Uranium Resources $\left(10^{3}\right.$ tons $\left.\mathrm{U}_{3} \mathrm{O}_{8}\right)$

\begin{tabular}{cccccc}
\hline & & \multicolumn{2}{c}{ Estimated } & Additional Resources & \\
\cline { 3 - 5 }$\left(\$ / 1 \mathrm{~b} \mathrm{U} \mathrm{U}_{3} \mathrm{O}_{8}\right)$ & Reserves & 300 & 200 & 30 & 730 \\
8 & 200 & 460 & 390 & 110 & 1275 \\
10 & 315 & 680 & 640 & 210 & 1950 \\
15 & 420 & 1140 & 1340 & 410 & 3490 \\
30 & 600 & Probable & Possible & Speculative & Total \\
\hline
\end{tabular}

expected that about 2 million tons of uranium will be needed by the year 2000 , bringing the price range during VHTR deployment to perhaps $\$ 30$ to $\$ 100 / 1 \mathrm{~b} \mathrm{U}_{3} \mathrm{O}_{8}$ (in current dollars). The uranium price would tend to be in the lower part of this range if breeders were widely used for electricity generation.

The sensitivity of VHTR fuel cost to uranium cost is shown in Fig. 18.

\section{CONCLUSIONS AND RECOMMENDATIONS - R\&D NEEDS}

\section{A. Conclusions}

1. Process temperatures up to the 1400 to $1500^{\circ} \mathrm{F}$ range are achievable with near-term technology. The major development considerations are high temperature materials, the safety questions (in particular regarding the isolation loop) and the reformer or process heat exchanger.

2. Process temperatures of $1600^{\circ} \mathrm{F}$ are somewhat more difficult and will demand an expanded materials program and probably more time.

3. Process temperatures in the range of $1600^{\circ} \mathrm{F}$ to $2000^{\circ} \mathrm{F}$ are potentially achievable but would require a much larger development program over a longer period of time. Some major uncertainties in this higher temperature range include heat exchanger design and materials (possibly ceramics), ducting and vessel insulation, fission product release and transport, safety and possibly advanced fuel particle design. 


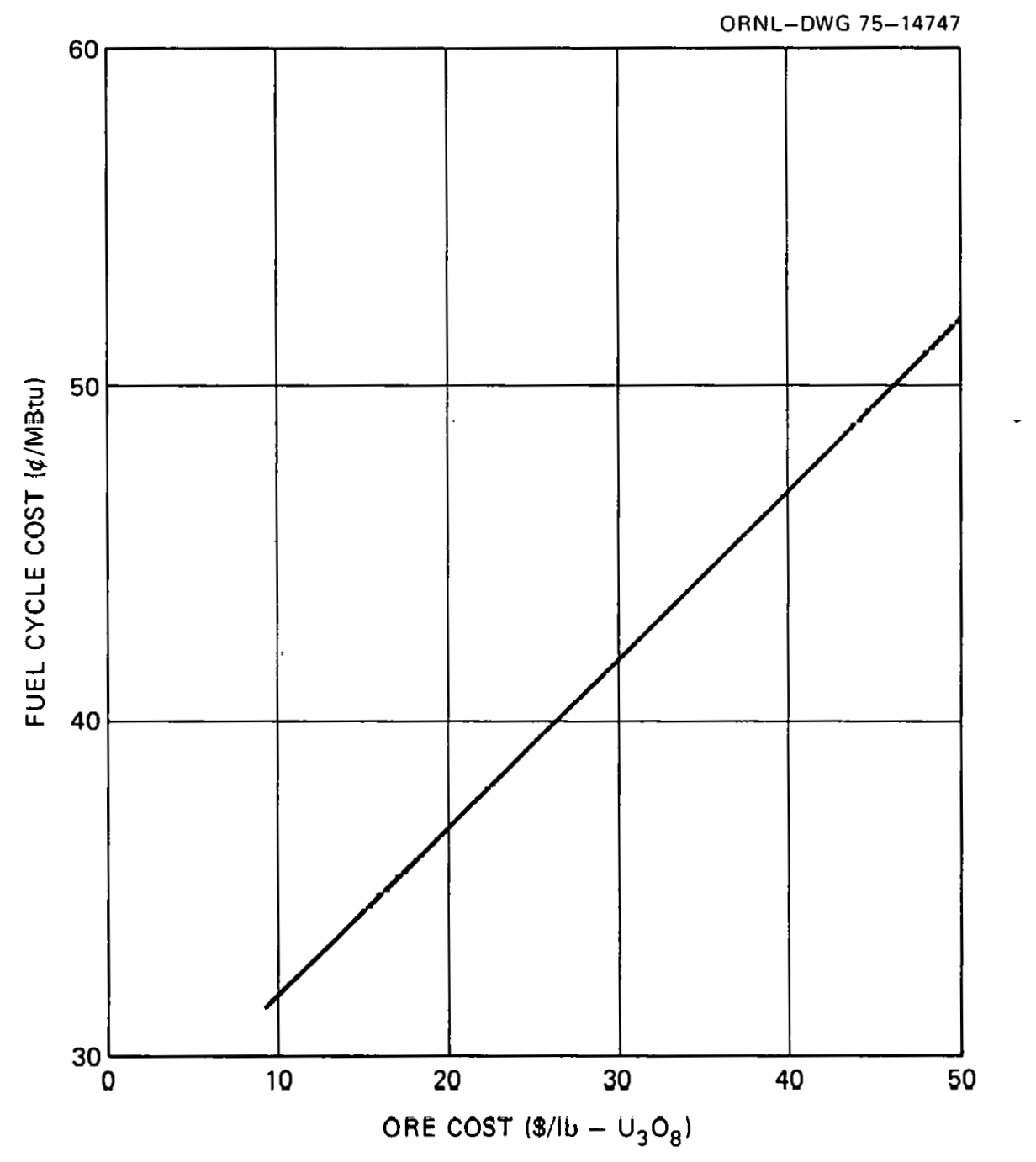

FIGURE 18. VHTR Fuel Cost, Thorium-Uranium Cycle 
4. Certain unique features of the VHTR concepts appear to require specific comment:

a. An isolation loop appears to be desirable from the standpoint of safety and very likely will be required for most process heat applications. The typical process fluids appear to have the potential for creating hazardous and damaging reactions in the primary reactor loop. An isolation loop would provide an opportunity to clean up contaminants from both the process and the reactor and avoid the introduction of process fluids into the reactor system and likewise avoid the potential release of radioactive contaminants. A purification system must be assumed as a part of the isolation loop.

Additional work to look at alternate design approaches for the isolation loop to reduce costs appears worthwhile.

b. The GA fuel concept appears adequate for the 1400 to $1600^{\circ} \mathrm{F}$ maximum process temperature range but at some small penalties in fuel cycle cost and/or pumping power as temperatures are increased. Beyond this temperature range, advanced fuel particle development is required.

The pebble bed fuel concept presented by GE appears capable of higher process temperatures than the GA prismatic fuel concept. The OTTO (Once through then out) cycle has not been demonstrated, however.

The Westinghouse fuel system would require more development than the other concepts.

c. The prestressed cast iron vessel (PCIV) proposed by Westinghouse could be very worthwhile and is recommended for additional study. This concept could save considerable cost and on-site construction time if remotely fabricated in a factory and assembled on site. The application of the PCIV is not limlted to the VHTR concept; therefore, it is recommended that the PCIV be evaluated as a part of the overall Gas-Cooled Reactor Program.

d. The use of gas turbines in the VHTR concept as proposed by Westinghouse is not recommended. This item alone would appreciably increase the cost and time required for the R\&D program. 
e. If an isolation loop is required, significant cost savings in PCRV (or PCIV) and containment building costs can be realized if steam generators are located only in the intermediate loop outside the PCRV. Also, this would eliminate the potential for steam ingress if the auxiliary coolant system and other miscellaneous applications of water (steam) were revised. In view of the higher temperature of the graphite moderator, inherent in higher outlet coolant temperature concepts, the elimination of potential steam ingress could be an important advantage in reactor safety.

5. The costs for nuclear process heat are expected to be comparable to process heat costs from oil at $\$ 8$ to $\$ 12 / \mathrm{barrel}$, or from coal at $\$ 1$ to $\$ 2$ per million Btu. Precise comparisons are premature and should await further development of complete process systems. A related factor is timing. The VHTR cannot be commercially deployed until the 1990s; at that time fossil fuel costs are expected to be much higher than today's costs, improving the competitiveness of the VHTR.

6. The VHTR appears to have significant environmental advantages for coal conversion, particularly in reducing atmospheric pollution, but these have not been evaluated here.

\section{B. Discussion of R\&D Program}

The gas-graphite reactor concept has had three highly successful experimental reactor demonstrations: the Dragon Reactor, the AVR Reactor, and the Peach Bottom HTGR. Further, power operation of the Fort St. Vrain HTGR is planned the first part of $19 \% 6$, and the THTR is scheduled for power operation in 1978. A strong research and development program is being carried out in HTGR technology, including areas such as fuels and materials, fuel recycle, chemistry and fission product behavior, graphite, PCRVs, reactor surveillance, and components testing. Primary USA parties engaged in this activity are General Atomic Company, Oak Ridge National Laboratory, and Idaho National Engineering Laboratory. The United Kingdom has also been carrying out a strong program on HTGR technology and design development, and Germany has a strong program, although development emphasis has been on the HTGR-GT and on nuclear process heat. France is also becoming significantly involved in HTGR technology development; further, a number of 
nations participate through the Dragon Project. Development has proceeded to the point where HTGRs appear to be commercially viable if a strong research and development program is continued in various areas. The HTGR fuel recycle area is one of concern, inasmuch as the technology has not yet been completely developed; the largest effort is being carried out in the USA where plans are being made for demonstrating fuel recycle technology in a demonstration plant. Germany is also carrying out significant work in fuel recycle technology, and plans a more extensive program in the future.

Table 18 is a summary of worldwide development pertinent to the VHTR. The U.S. VHTR program is still in the formative stage. Each vendor study considered an R\&D program to develop the concept. Table 19 presents a very preliminary estimate of the R\&D program costs to achieve a process temperature of 1400 to $1600^{\circ} \mathrm{F}$ based on a review of the vendor estimates. such a program could be completed in 6 to 10 years.

As pointed out previously, it is premature at this time to draw conclusions about the cost-benefit of the VHTR concept. Likewise, it is premature to recommend an overall R\&D effort. However, there are two interrelated areas of development work which are recommended at this time. The first area of development work is the IHX or intermediate loop and the second area is materials development.

Additional work is needed to determine in a definitive manner whether or not the IHX is required, and if so to look into alternative design approaches to reduce cost.

The materials development program discussed in section IVC is a critical need.

It would also be appropriate to initiate some safety-related studies. VHTR safety and safety-related technology should be assessed promptly in order to identify and hopefully resolve key concerns of importance to public safety. Background information presented in the vendor reports provides a starting point. Preliminary results indicate that fission product, primary coolant, and primary system materials technology are areas in which safety studies should be initiated first.

Later in the R\&D program, major test facilities will be requiren to develop process design parameters and to prove the feasibility and durability of high temperature components. 
Table 18

Worldwide VHTR Development Activities

\begin{tabular}{|c|c|c|c|c|c|}
\hline & USA & Germany & UK & Japan & $\underline{\text { France }}$ \\
\hline VHTR Concept Development & + & ++ & + & + & + \\
\hline Commercial Reactor Supply & ++ & ++ & & & \\
\hline Component Development & ++ & ++ & & & ++ \\
\hline Nuclear Fuel Cycle Facilities & ++ & ++ & & & \\
\hline Fuels & ++ & ++ & ++ & + & \\
\hline Materials & ++ & ++ & ++ & ++ & + \\
\hline Methane Reformer & & ++ & & & \\
\hline Matching Coal Conversion & & ++ & & & \\
\hline Nuclear steelmaking & + & + & + & ++ & \\
\hline
\end{tabular}

Table 19

Preliminary Estimate of R\&D Program Costs

$\$$ Mi1l11on

IHX

Steam Reformer 25

Materials 30

Components and Systems Layout $35^{\circ}$

Fuel and Core Components 18

Pressure Vessel 11

Component Development $\quad 16$

Safety 16

Contingency, 258 
A demonstration reactor in the size range of $1000 \mathrm{MW}(t)$ to $3000 \mathrm{MW}(t)$ will be required. Such a plant would cost approximately $\$ 1$ billion (in 1974 dollars) according to recent projections, and might be authorized about 1981 to 1985 for operation in the 1990s.

The German program currently is based on the target of a demonstration pebble-bed VHTR demonstrating coal conversion, to be started up in the late 1980s. The plant would be sized at $750 \mathrm{MW}(t)$. 
1. High-Temperature Nuclear Heat Source Study, General Atomic Company, GA-Al31.58 (December 30, 1974).

2. The VHTR for Process Heat - Draft, General Electric Company, GEAP-14018, Vols. I and II (September 1974).

3. The Very High Temperature Reactor for Process Heat, Westinghouse Electric Corporation, WANL-2445-1 (December 1974).

4. E. A. Womack, Jr. and K. O. Laughon, "AEC Programs for Nuclear Process Heat Development," Proc. First National Topical Meeting on Nuclear Process Heat Applications, Los Alamos, N.M., October 1-3, 1974, LA 5795 … P. 93 (November 1974).

5. The Pebble Bed High-Temperature Reactor as a Source of Nuclear Process Heat, Kernforschungsanlage Julich, Vol. 7, Processes of Nuclear Heat, Jul-1119-RG (October 1974).

6. H. Harder (HRD) and R. Fischer (GHT), "Nuclear Process Heat Programes in Germany," Proc. First National Topical Meeting on Nuclear Process Heat Applications, Los Alamos, N.M., October 1-3, 1974, LA-5795-C, p. 147 (November 1974).

7. Final Report - Application Study of a Nuclear Coal Solution Gasification Process for Oklahoma Coal, General Atomic/Stone \& Webster, GA-A12068, Vol. I (May 1972).

8. Rudolf Schulten and Kurt Kugeler, "Coal Gasification and Other Nuclear Process Heat Applications," Proc. First National Topical Meeting on Nuclear Process Heat Applications, Los Alamos, N.M., October 1-3, 1974, LA-5795-C, P. 210 (November 1974).

9. Gasification of Coal with Nuclear Process Heat, Minister fur Wirtschaft, Mittelstand und Verkehr des Landes Nordrhein-Westfalen, Dusselforf, Translated by R. G. Mansfield, ORNL, from German, ORNL-tr -4002 (July 1974).

10. Gordon Brown, G. E. Harrison, C. W. Gent and J. Plummer, "Survey of Appropriate Endothermic Processes for Association with the HTR," British Nuclear Energy Society International Conference November 26-28, 1974 , p. 3.1.

11. The Pebble Bed High Temperature Reactor as a Source of Nuclear Process Heat, Kernforschungsanlage Julich, Vol. 1, Conceptual Design, JuL-1113-RG (October 1974).

12. F. E. Schilling, B. Beine, and H. Gross, "The Prestressed Cast Iron Pressure Vessel: Its Applicability for Gas and Water-Cooled Nuclear Power Reactors and for Impact Load Protection," Paper G 2/8, Source Unknown. 
13. H. Inouye and C. T. Liu, Low-Pressure Oxidation of T-1ll and Effect on Tensile Properties, Oak Ridge National, ORNL-TM-4621 (August 1974).

14. H. E. McCoy, "The Influence of Various Gaseous Environments on the Creep-Rupture Properties of Nuclear Materials Selected for HighTemperature Service," Proc. of the Conference on Corrosion of Reactor Materials, Vol. 1, Vienna, International Atomic Energy Agency, 263-296 (1962)

15. D. S. Wood, M. Farrow, and W. T. Burke, "A Preliminary Study of the Effect of Helium Environment on the Creep and Rupture Behavior of Type 316 Stainless Steel and Incoloy 800," Effects of Environment on Material Properties in Nuclear Systems, British Nuclear Energy Society Conference on Corrosion, pp. 213-220 (1971).

16. L. H. Kirschler and R. C. Andrews, "A Limited Comparison of the Mechanical Strength of Austenitic Steel in $1200^{\circ} \mathrm{F}$ Sodium, Air, and Helium," Trans. ASME. J. of Basic Engineering, ASME Paper 69-Met-3 (1969).

17. A. F. Weinberg and J. M. Scoffin, Exposure of Reactor Structural Materials to Impure Helium at Elevated Temperatures, General Atomic, GA-2998 (March 1962).

18. F. N. Mazandarany, Effects of Elevated Temperature Exposure to a Simulated HTGR Primary Coolant Environment on Several Unstressed Austenitic Alloys, General Atomic, GA-Al3462 (August 1975).

19. H. E. MCCoy and D. A. Douglas, "Effect of Various Gaseous Contaminants on the Strength and Formability of Columbium," Columbian Metallurgical Society Conferences, V. 10, Edited by D. L. Douglas and F. W. Rungz, Interscience, pp. 85-118 (1961).

20. J. Stroop and P. Shahinian, The Effect of Nitrogen on the Tensile and Creep Rupture Properties of Niobium, NRL-6464 (October 31, 1966).

21. C. T. Liu and $\mathrm{H}$. Inouye, Mechanical Properties and Interstitial Contaminants in a Molybdenum-Base Alloy, TZM, Oak Ridge National Laboratory, ORNL-4238 (August 1973).

22. L. A. Charlot, R. E. Westerman and R. A. Thiede, Corrosion of Superalloys and Refractory Metals in High Temperature Flowing Helium, BNWL-SA-1137 (1967).

23. W. T. Chandler and R. J. Watten, "Hydrogen Effects in Refractory Metals," Refractory Metal Alloys, Plenum Press, New York, pp. 197-249 (1968).

24. F. H. Norton, "Pure Beryllium Oxide as a Refractory," J.Am. Ceram. Soc. $\underline{30}, 242$ (1947).

25. L. I. Grossweiner and R. L. Sheifert, "Reactions of Beryllium Oxide with water Vapor," J. Am. Chem. Soc., 74, 11, 2701-2704 (1952). 
26. O. J. Whittenmore, Jr., "Properties and Uses of Pure Oxide Heavy Refractories," J. Am. Ceram. Soc., 32, 2 , pp. 48-53 (1949).

27. High Temperature Technology, Edited by I. E. Campbell, John Wiley and Sons, Inc., New York, p. 118 (1956).

28. F. N. Mazandarany and P. L. Rittenhouse, Effects of Service Environments on the Behavior of HTGR Steam Generator Structural Materials, General Atomic, GA-A13553 (July 15, 1975).

29. A. K. Chakraborty, Literature Review and Test Plan on General Corrosion of Ferritic and Austenitic Steam Generator Materials in Superheated Steam Under Isothermal and Heat Transfer Conditions, NEDG 13860 (May 1972).

30. F. A. Comprelli and U. E. Wolff, Stability of High-Nickel Alloys in Superheated Steam, GEAP-4745 (November 1964).

31. T. T. Claudson and H. J. Pessl, Evaluation if Iron- and Nickel-Base Alloys for Medium and High Temperature Reactor Applications : Part II, BNWL-154 (November 1965).

32. F. Eberle and C. H. Anderson, "Scaling Behavior of Superheater Tube Alloys in ASME High Temperature Steam Research Tests at $1100-1500^{\circ} \mathrm{F}, "$ Trans. ASME, Ser. A. J. Eng. Power 84 (1962).

33. W. L. Pearle, et al. General Corrosion of Incoloy 800 in simulated Superheat Reactor Environment, GEAP-4497 (1964).

34. W. L. Pearl, et al., General Corrosion of Materials for Nuclear Superheat Applications, GEAP-4760 (March 1965).

35. S. Leistikow, et al., Incoloy Alloy 800 Steam Corrosion Experiments Under Heat Transfer and Isothermal Steam Corrosion Testing Various Superheat Materials in a High Pressure Loop," Kernforschungszentrum Karlsruhe, KFK-2033.

36. P. Patriarca, et al., ORNL Program Plan and Review for $21 / 4 \mathrm{Cr}-1 \mathrm{Mo}$ Steel Steam Generator and Heat Exchanger Materials, Oak Ridge National Laboratory, ORNL-TM-4473 (February 1, 1974).

37. J. P. Hammona, et al., "Chloride Stress-Corrosion of Steam Generator Materials and Post-Test Analysis of an Incoloy 800 Loop," Paper Presented at the National Association of Corrosion Engineers 30th National Conference, Chicago, Illinois, March 4-8, 1974.

38. D. I. Roberts, J. F. Hildebrand and R. Stetson, Autoclave Corrosion Tests of Welded and Bent Steam Generator Tubes for PSC, General Atomic, GA-9299 (April 30, 1969).

39. C. T. Sims and W. C. Hagel, Eds., The Superalloys, John Wiley and Sons, New York, 1972. 
40. Code of Federal Regulations, Title 10, Part 100 Reactor Site Criteria (January 1, 1975).

41. Studies of the Use of High-Temperature Nuclear Heat from an HTGR for Hydrogen Production, General Atomic, GA-A13391, Prepared Under Contract for NASA (September 30, 1975).

42. Small Nuclear Process Heat Plants (SNPH) Using Pebble-Bed Reactor, General Electric Company, GEEST 75-001 (September 1975).

43. Statistical Data of the Uranium Industry, GJO-100(75), January 1975. 
THIS PAGE

WAS INTENTIONALLY

LEFT BLANK 
INTERNAL DISTRIBUTION

1. T. D. Anderson

2. C. D. Baumann

3. R. H. Cooper

4. W. B. Cottrell

5. F, L. Culler

6. J. G. Delene

7. J. R. Distefano

8. G. G. Fee

9. E. C. Fox

10. W. Fulkerson

11. L. C. Fuller

12. W, R. Gambill

13. M. J. Goglia

14. H. W. Hof fman

15. J, E. Jones Jr.

16. P. R. Kasten

17. O. H. Klepper

18. C. C. Littlefield
19. R. E. MacPherson

20. W. J. McCarthy, Jr.

21. J. P. Nichols

22. H. Postma

23. P. L. Rittenhouse

24. T. H. Row

25. Myrtleen Sheldon

26. M. D. Silverman

27-36. I. Spiewak

37. J. J. Taylor

38. D. B. Trauger

39. J. R. Weir

40. G. D. Whitman

41. W. J. Wilcox

42. ORNL Patent office

43-44. Central Research Library

45. Document Reference Section

46-48. Laboratory Records Dept.

49. Laboratory Records (RC)

\section{EXTERNAL DISTRIBUTION}

50. Asst. Administrator for Fossil Energy, ERDA, Washington, D.C. 20545

51. Deputy Asst. Administrator for Fossil Energy, ERDA, Washington, D.C. 20545

52-53. Director, Div. of Fossil Energy Research, ERDA, Washington, D.C. 20545

54. Director, Div. of Coal Conversion and Utilization (CCU), ERDA, Washington, D. C. 20545

55. Zeke Clark, CCU, ERDA, Washington, D. C. 20545

56-61. Mayo Carrington, CCU, ERDA, Washington, D. C. 20545

62. R. E. Vener, CCU, ERDA, Washington, D. C. 20545

63. Director, Div. of Nuclear Research and Applications (NRA), ERDA, Washington, D. C. 20545

64. T. Beresovski, NRA, ERDA, Washington, D. C. 20545

65. E. G. Delaney, NRA, ERDA, Washington, D. C. 20545

66. D. E. Erb, NRA, ERDA, Washington, D. C. 20545

67. K. O. Laughon, NRA, ERDA, Washington, D. C. 20545

68. J. C. Montgomery, NRA, ERDA, Washington, D. C. 20545

69. R. G. Oehl, NRA, ERDA, Washington, D. C. 20545

70. A. R. Landgrebe, Div. of Conservation Research and Technology, ERDA, Washington, D. C. 20545

71. R. N. Quade, General Atomic Co., P. O. Box 81608, San Diego, Calif. 92138

72. A. T. McMain, General Atomic Co., P. O. Box 81608, San Diego, Calif. 92138

73. G. H. Farbman, Westinghouse Elec. Corp., Astronuclear Lab., P. O. Box 10864, Pittsburgh, Pa. 15236

74. A. R. Jones, Westinghouse Elec. Corp., Astronuclear Lab., P. O. Box 10864, Pi ttsburgh, Pa. 15236 
75. A. E. Kakretz, General Electric Co., Fairfield, Conn. 06431

76. O. G. Woike, General Electric Co., P. O. Box 15132, Cincinnati, Ohio 45215

77. J. B. Newman, United Engineers \& Constructors, 1401 Arch St., Philadelphia, Pa. 19105

78. J. H. Crowley, United Engineers \& Constructors, 1401 Arch St., Philadelphia, Pa. 19105

79. D. J. Blickwede, Bethlehem Steel Corp., Bethlehem, Pa. 18016

80. T. F. Barnhart, U.S. Steel Corp., 125 Jamison Lane, Monroeville, Pa. 15146

81. K. W. Weraes, Amoco U1l Co., Box B110A, Chlcago, Ill. 80880

82. D. C. Azbill, Shell Oil Co., One Shell Plaza, P.O. Box 2463, Houston, Texas $\%$ UU1

83. F. M. Richmond, Universal-Cyclops, 650 washington Rd., Pittsburgh, Pa. 15228

84. Derek Gregory, Inst. of Gas Tech., 3424 So. State St., Chicago, Il1. 60616

85. R. J. Jiacoletti, Los Alamos Scientific Lab., P.O. Box 1663, Los Alamos, N.M. 87544

86. Donald Bogart, National Aeronautics and Space Admin., 6390 Nelwood Rd., Cleveland, Ohio 44135

87. D. R. Stone, National Aeronautics and Space Admin,, Washington, D. C. 20546

88. Jack G. Conners, Battelle-Columbus Lab., 505 King Ave., Columbus, Ohio 43201

89. Seymour Alpert, Electric Power Res. Inst., 3412 Hillview Ave., Palo Alto, Calif. 94304

90. R. Wright, American Petroleum Inst., $1801 \mathrm{~K}$ St. NW, Washington, D.C. 20006

91. A. Flowers, American Gas Association, 1515 Wilson Blvd., Arlinqton, Va. 22209

92. W. C. Helt, National Coal Assoc., 1103 17th St., NW, Washington, D.C. 20036

93. W. W. Talley, Resource Analysis \& Management Group, 2500 First National Center, Oklahoma City, Okla. 73102

94. Don Crego, Gilbert Associates, 525 Lancaster Ave., Reading, Pa. 19603

95. Reautor Divisiun, ORO, OR

96. Res. and Tech. Support Div., ORO, OR

97-123. Technical Information Center 